ORNL-4313-3

UC-80 - Reactor Technology

Contiant ith. W-i40s-eng-26

DIHESTCR'S DIVISION

FABAICATION PRLCEDURES AND ACCEPTANCE DATA FOR ASTM A-533 WELDS AND A

10in.thick ASTM A-EAS PLOTTE GF THE HEAYY SECTION

STEEI. TECHNOL OGY FRCARAR, DOCUMENTARY

REPOR: 3

C. E. Chinttess

LEGAL NOTICE

This report wo jrepared as an sccount of work sponsored by the United States Government. Neiticer the United Sintes nor the United Sintes Atomic Eneryy Comminaion, nor any of their e.ipioyees, nor any of thei contractors, subcontractors, or their employees, makes any warraty, express or implied, or secumes any leol linbility of responsibitity for the accuracy, cumlepal linbility of responsibitity for the accuracy, cumproduct or proces disclosed, or represents that its use would not infringe privtely owned rights.

JÁNIJARY !:771

OAK RIDGE NATIONAL LABORATOAY

Ock Rider, Tennowases

opereven by

UN OII CARBIDE CORPORATIOY

for the

U. 8. ATOMIC ENEROY COMmSBION 


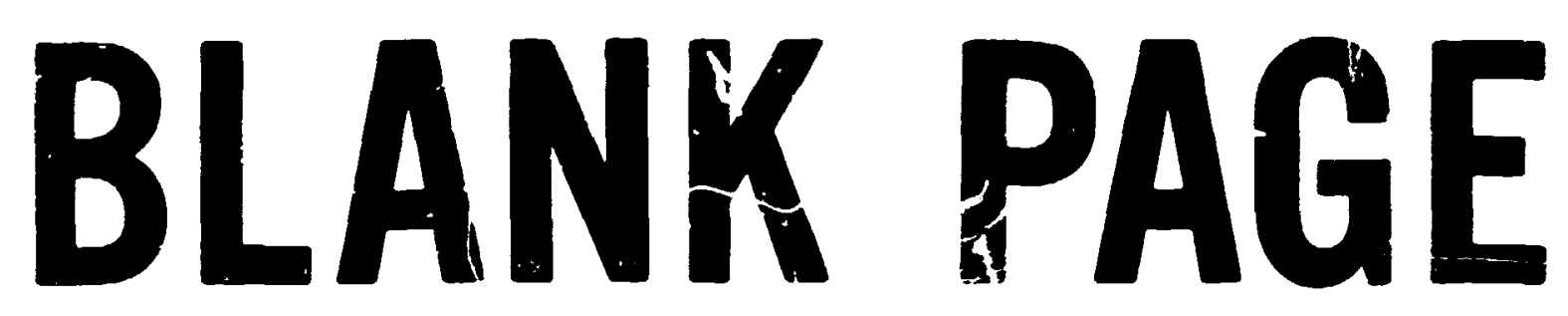




\section{CONTENTS}

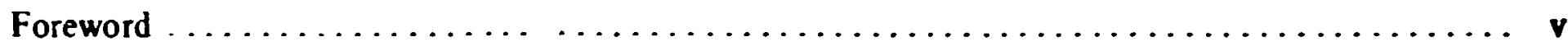

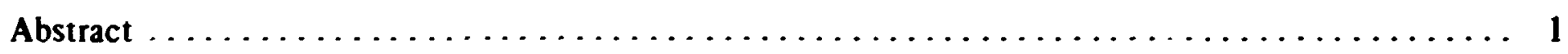

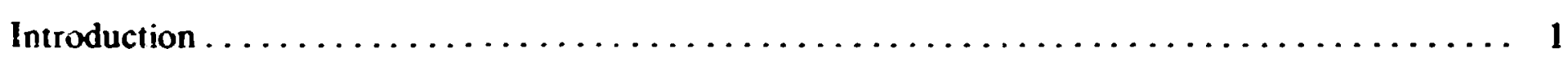

\section{ASTM A-543 Plate}

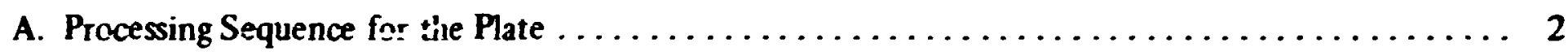

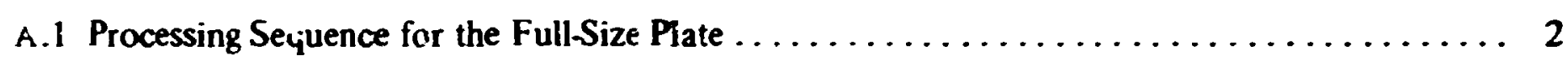

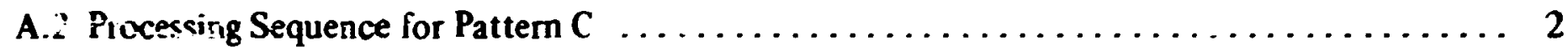

A.3 rrocessing Sequenc: for Patterns $\mathbf{A}$ and B Combined $\ldots \ldots \ldots \ldots \ldots \ldots \ldots \ldots \ldots \ldots \ldots \ldots \ldots$

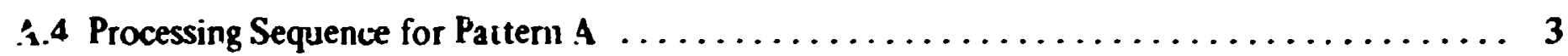

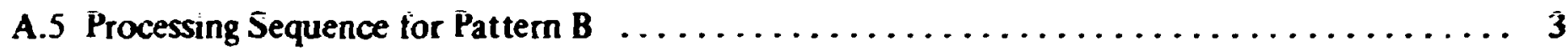

B. Rolling and Preliminary Testing of the Full-Size Plate $\ldots \ldots \ldots \ldots \ldots \ldots \ldots \ldots \ldots \ldots \ldots \ldots$

C. Ultrasonic inspection before Heat Treatment $\ldots \ldots \ldots \ldots \ldots \ldots \ldots \ldots \ldots \ldots \ldots \ldots \ldots$

C.1 Longitudinal-Wave Inspection $\ldots \ldots \ldots \ldots \ldots \ldots \ldots \ldots \ldots \ldots \ldots \ldots \ldots \ldots \ldots \ldots \ldots \ldots \ldots \ldots \ldots \ldots$

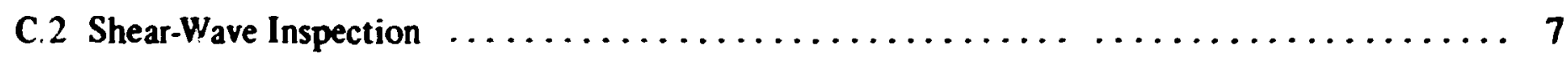

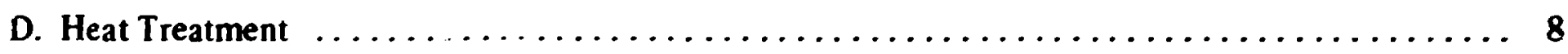

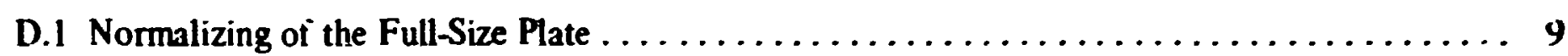

D.2 Austenitizing and Quenching of the Full-Size Plate $\ldots \ldots \ldots \ldots \ldots \ldots \ldots \ldots \ldots \ldots$

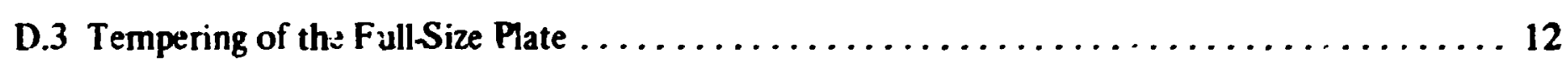

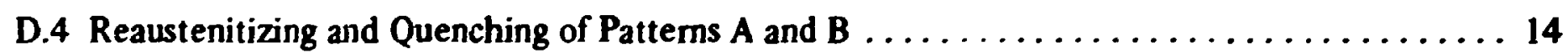

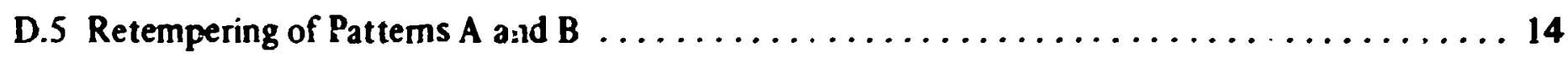

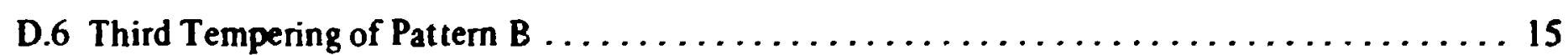

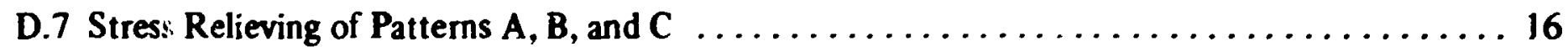

D.8 Stress Relieving of Patterns A, B, and C after Removal of Test Material . . . . . . . 16

D.9 Retempering of Patterns A, B, and $C$ after Mechanical Testing $\ldots \ldots \ldots \ldots \ldots \ldots \ldots$

E. Chemical Analysis and Retesting for Mechanical Properties $\ldots \ldots \ldots \ldots \ldots \ldots \ldots \ldots \ldots$

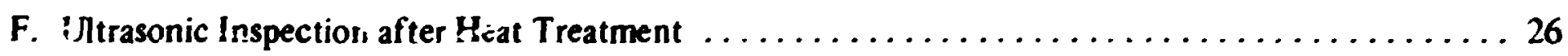

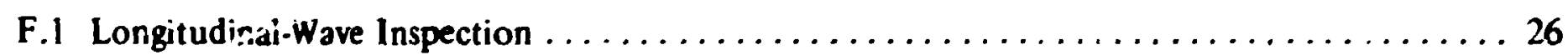

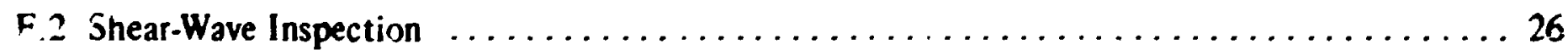

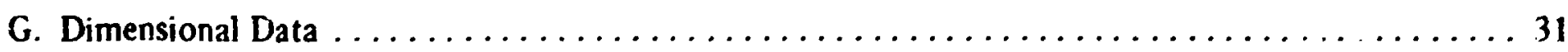




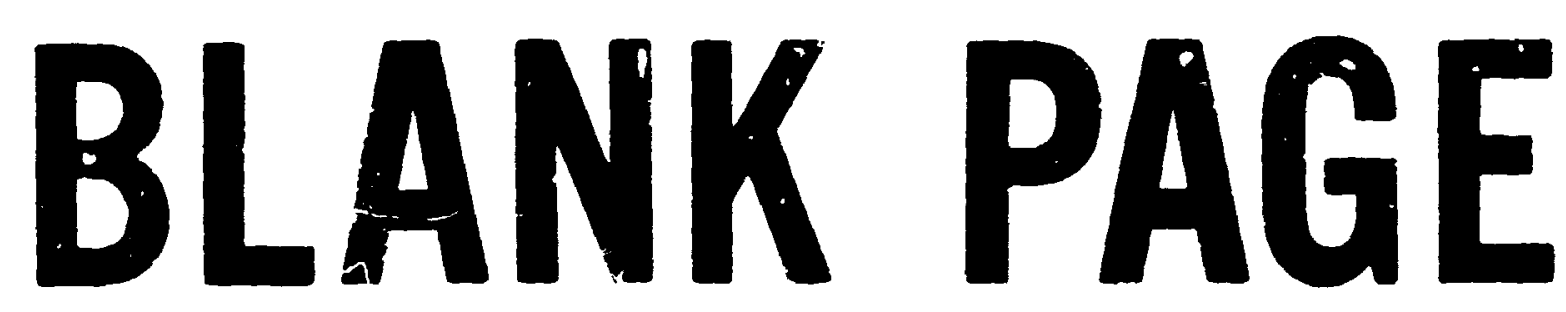




\section{Weldments}

H. Fabrication of Weldments from Plate Sections of HSST Plate $01 \ldots \ldots \ldots$

H.1 Fabrication and Inspection of the Shielded-Metal-Arc Weldment $\ldots \ldots \ldots \ldots \ldots$

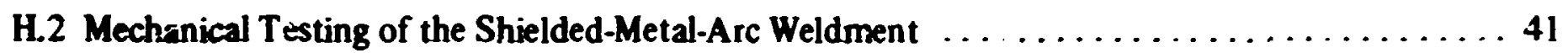

H.3 Fabrication and Welding of the Submerged-Arc Weldments . . . . . . . . . . . . 46

H.4 Mechanical Testing of Submerged-Ari Weldment $51 \ldots \ldots \ldots \ldots \ldots \ldots \ldots \ldots$

I. History of a $6 \frac{1}{4}$-in.-thick Electroslag Weldment Donated to th.e HSST Program .... . . . . . . 5ô

3. Fabrication and Welding of a 6-in.-thick ASTM A-533 Grade B, Class 1 Plate

J. Fabrication of 6 -in.-thick ASTM A-533 Grade B, Class 1 Plate . . . . . . . . . . . . . . 64

K. Fabrication of Weldments from the 6-in.-thick ASTMI A-533 Grade B, Class 1 Plate ........68

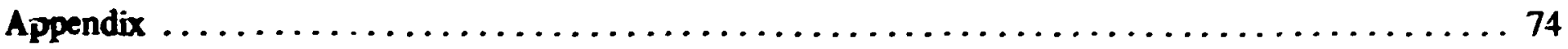




\section{FOREWORD}

The work described in this report has been irried out under the Heavy Section Steel Technology (HSST) Program. The HSST Program is a USAEC sponsored effort for investigating the effects of flaw,, variations of properties, stress raisers, and residual stress on the strength and structural reliability of present and contemplated water-cooled reactor pressure vessels. The cognizant engineer for the USAEC is J.R. Hurter. At ORNL the program is under the Pressure Vessel Technology Program. This report is designated Heavy Section Steel Technology Program Documentary Report No. 3. Prior issues in this serie: are ORNL-4313 and ORNL43!3-2. 


\title{
Fabrication Procedures and Acceptance Data for ASTM A-533 Welds and a 10-in.-thick ASTM A-543 Plate of the Heavy Section Steel Technology Program, Documentary Report 3
}

\begin{abstract}

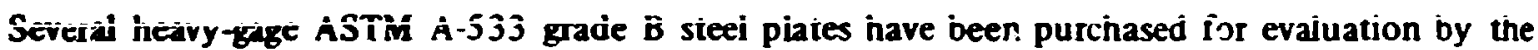
Heavy Section Steel Techislogy (HSST) program. The fabrication histories of these plates were presented in ORNL-4313 aid ORNL-4313-2.

To provide weddments for investigation, practically all of the edge material from the first HSST phate was used to fabricate submerged-arc and shielded-metal-arc weldments. The weldments were made by fabricators who produce nuclear reactor pressure vessels and related components to the requirements of Sect. Ill of the ASME Code for Nuclear Vessels. Each of the weldments was made in accordance with Code requirements, and the welding parameters and available test data are presented.

An effort was maje to procure an electroslag weldment made to the requirements of Sect. III. However, no vendors were currently using this process in the fabrication of nuclear pressure vessels. A portion of an electroslag weldment was donated to the HSST program by the General Electric Corporation. Datia relative $t$ t this weldment are presented in addition to the data for submerged-arc and shielded-metal-are weldments.

To provide additional base material for investigation, a 10-in.-thick ASTM A-543 steel plate was purchased. This report provides the fabrication and processing history of that A-543 plate.
\end{abstract}

\section{INTRODUCTION}

The Heavy Section Steel Technology (HSST) Program is a cooperative engineering effort designed to assess the structural reliability of light-water reactor pressure vessels containing material inhomogeneities and other intperfections under startup, operating, and accident conditions. In recent years the generai public has begun to question seriously the integrity of reactor systems, especially those located in large urban areas. Federal regulatory and licensing bodies and the Advisory Committee on Reactor Safeguards have also raised similar questions. As a consequence, the HSST program was initiated to develop sufficient quantitative means for assuring the integrity of reactor vessels against the probability of brittle fracture.

Since its inception the HSST program has maintained close liaison with other research efforts of related interest, many of which are sponsored by the federal government, private institutions, and industry.

Several heavy-gage steel plates ( 12 in. thick) made to the requirements of ASTM A-533 grade B (classes 1 and 2) have been purchased as a material supply for research. Much of this material has been channeled into an ambitious experimental proyram, and data obtained from the tests are available in the technical literature. To provide weld metal for evaluation, sections of edge material from the first 12-in.-thick plate were made into weldments using the shielded-metal-arc and the submerged-arc processes. Additionally, a 6-in.-thick ASTM A-533 grade B class 1 plate was purchased, cut into six sections, and rejoined by the submerged-arc process to form two separate weldments.

In order to extend the investigative effort to include additional types of steel, a 10-in.-thick ASTM A-543 plate was purcilased. Thie first section of this report describes in detail the melting and fabrication history of the A.543 plate; the second section is concerned with the details of weldments procured for investigation; and the final section deals with the melting, fabrication, anc walding of the 6-in.-thick A-533 grade B, class I plate. 

The purpose of this repcitt is to provide researchers and analysts with a historical record of the materials and fabrication processes descrived above. The intent is to provide a record which is as complete and objective as pasible. Accordingly, no interpretation of datis or of test rerorts is iniluded except where considered essential to the unde-standing of the reader. The author wishes $: 9$ dic ik the roi'owing for their assistance and for making essential test data avalaivie for this report: (1) The Mietallurgical Department of Lukens Steel Company, particularly S. G. Johnson and E. K. Mar'!ni; (2) Combustion Engineering Company, particularly Trig Halvorsen; (3) Cinsago Bridge \& Iron Company, particularly David Pugh; (4) L. J. Chockie, Secretary of the PVRC Task Group on Materials Properties; and (5) D. A. Canunico and K. K. Klindt of the Oak Ridge "'ational Laboratory.

\section{ASTM A-543 PLATE}

The originally conc:ive:s proessing sequence for the 10 in.thick ASTM A-543 plate is as follows.

\section{$\therefore$ PROCESSING SEQUENCE FOR THE PLATE}

\section{A.1 Processing Sequence ior the FullSize Plate}

1. Melt and roll plate material.'

2. Mark plate to identify top and bettom surfaces.

3. Ultraso:ically inspect plate.

4. Mark place to delineate three separate patterns (patterns A, B, and C).

5. Jrill $1 / 4$-in.-diam holes abo $\mathrm{At} 3$ in. inside each pattern corner on both top and bottom surfaces.

6. Measu,e and record the relative location of each $1 / 4$-in.-diam hole, end to end, side to side, and jiagonally.

7. Preheat to $500^{\circ} \mathrm{F}$ anci gas rut to 120 -in. width (overroll material at top and buttom ingot ends not removed).

8. Normalize plate.

9. Repeat step 6.

10. Install six thermocuuples.

i:. Alstenitize plate.

12. Quench piate in agitated water.

13. Temper plate to class 1 mechanical properties.

14. Repeat step 6.

15. Preheat to $500^{\circ} \mathrm{F}$ and separate partern $\mathrm{C}$ from the remainder of the plate by gas cutting.

\section{A.2 Processing Sequence for Pattern C}

i. Surss rolieve pattern $\mathrm{C}$ for $56 \mathrm{hr}$ and furnace cool.

2. Repeat step A.1.6.

3. Freheat to $500^{\circ} \mathrm{F}$ and gas cut test material from pattern.

\footnotetext{
'All operations were performed by Luxens Stee! Company.
} 
4. Stress relieve for $4 \mathrm{hr}$ and air cool.

5. Ultrasonically inspect patteri $C$.

6. Repeat sit'p A.1.6.

\section{A.3 Processing Sequence for Pattems A and B Combined}

1. Repeat step A.I.

2. Stress relieve patisms $A$ and $B$ for $4 \mathrm{hr}$ following removal of pattern $C$.

3. Repeat step A.1.6.

4. Reinstall thermocouples.

5 Reaustenitize s!d quench patterns $A$ and $B$ in agtated water.

6. Temper patterns $A$ and $B$ i class 2 mechanical properícs.

7. Repeat step A.1.6.

8. Preheat coinbined patterns $A$ and $B$ to $500^{\circ} \mathrm{F}$ and separate by gas cutting.

\section{A.4 Processing Sequence for Pattern A}

1. Stress relieve pattem $A$ for $50 \mathrm{hr}$ and furnace cool.

2. Repeat step A.1.6.

3. Preheat to $500^{\circ} \mathrm{F}$ and gas cut test material from pattern.

4. Stress relieve for $4 \mathrm{hr}$ and air cool.

5 Ultrasonically inspect pattern $\mathbf{A}$.

\section{A.5 Processing Sequen' a for Pattern B}

1. Immediatelv foliowing separation from pattern A retemper pattern B to class 1 mechanical properties.

2. Repeat $s t e p$ A.1.6.

3. Stress relieve pattern B tor $50 \mathrm{hr}$ and furnace cool.

4. Repeat step A.1.6.

5. Preheat to $500^{\circ} F$ anu gas cut test material from pattern.

6. Stress relieve for $4 \mathrm{hr}$ and air cool.

7. Ultrasonically inspect pattern $B$.

8. Ship all inaterial to the HSST storage area.

\section{B. ROLLING AND PRELIMINARY TESTING OF THE FULL-SIZE PLATE}

A purchase, oider was negotiated with Lukens Steel Coinpany on July 17, i963, which specified that Lukens provicie a 10-in.-thick steel plate made to the requirements of ASTM A-513-67 and case 1358-1, $\therefore$. Aified per Cumpany's specification JS-120-128. Essentially the modifis:tion required:

i. phosphorus to be as low as possible, restricted to $0.0 \mathrm{i} 5 \% \mathrm{max}$, ladle anaiysis only;

2. sulfur to be as low as possible, restricted to $0.020 \%$ max, ladle analysis only;

3. vanadium to be restricted to $0.03 \%$ max. ladle a nalysis only;

4. carbon to be a: low as possible, restricted to 0.20 max, ladle analysis oni $;$; 
5. in the final form, pattern A (top midsaction) is be double austenitized and tempered to class 2 mectanmià properties; pattern B (bottom 12-ft s:ction) to be double austenitized and tempereci iú clasis ' mecharical properties; and pattern C (top ingot end) to be single austenitized and tempered to class 1 mechanical properties;

6. Lukens 10 j:r $\mathrm{fcm}$ drop weight tests to determined nilductility transition iemperature and longitudinal and transvers: Charpy V-notch testing, with transition curves.

The materials, for the plate, Lukens heat B9042, were meltci in a basic elesiric furrace, vacuum degassed, and bo!tom peured inio ingot form. Total ingot weight was about $138,000 \mathrm{lb}$. Chemical analysis of the ladle contents showed the following:

\begin{tabular}{|c|c|c|c|c|c|c|c|c|c|}
\hline $\mathbf{M n}$ & $\mathbf{P}$ & $\mathbf{S}$ & $\mathrm{Cu}$ & $\mathbf{N i}$ & $\mathbf{C}_{\mathbf{r}}$ & Mo & $\mathbf{S i}$ & A & $\mathbf{v}$ \\
\hline $0.3 j$ & 豸..0ii & $\hat{0.0015}$ & 0.16 & 3.42 & 1.65 & 0.57 & D.24 & טิ.ưi: & ก.820 \\
\hline
\end{tabular}

During the fir st rolling (slabbing) operation, the ingot was reduced to about 28 in. thick and slow cooled. The slab vas then condition ground, rekeated, and rerolled to the firal thickness of $10 \mathrm{in}$. on . October 7, 1968. (vverall length and width dimensions were 338 and 140 in. respectiveiy. Following the final rolling operation, the plate was $s$ ind cooled to ambient temperature.

Since the plaies were to be processec i uy the manufacturer, test material would be cut from the plates in the heat-treated condition. Lukens, therefore, requested and was permisted to use their DATA TRAC ${ }^{2}$ test method (Programmed Testing Procedure) in lieu of the so-called "3T" test specified in A-543-67. The results of the required physical tests are listed in a later section of this report.

\section{ULTRASONIC INSPECTION BEFORE HEAT TREA TMENT}

Lukens performed the first ultrasonic inspection of the full-size plate or O.: 10:8. Testing was performed in accordance with Attachments $2 A$ (longitudiral wave) and 2B (shear wave) of the PVRC Subcommittee Report of April 10, 1967. Copies of these Attachments are included in iirs Appendix.

The ultrasonic inspeciion prior to heat treatment was pirformed to lucate and record any discontinuities, for comparison with the ultrasonic inspection results after heat treatment. Longitudinal-

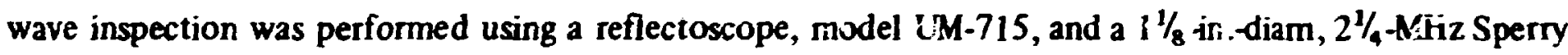
SC2A style 50A300 quartz transducer. The same equipment was used for shear-wave inspection except that a $1 X^{\prime}$ in., $45^{\circ}, 1-\mathrm{MHz}$ crystal was substituted. A couplant of liquid soap and water was used for all testing.

\section{C.1 Longitudinal-Ware Inspection}

The Midvale-Heppenstall reference block, shown in Fig. 1.1, was ised to calibrate the ultrasonic equipinent. The block was made from vacuum-arc-remelted, double-quenched, and tempered steel with a chemical composition quite similar to ASTM A-508 class 2 steel. The anplitude of reflection from each of the holes (bottom trilled for longitudinal-wave inspection and side drilled for shear-wave inspection) was recorded to relate signal amplitude to the depth below the scanilea surface. Points of peak amplitude from each of the reference holes were plotted on the instrument screen, and these were cor nected to form : distance-amplitude correction (DAC) curve.

\footnotetext{
${ }^{2}$ Jotin H. Scott, New Fest Method Promises Major Cost Savings in Construction of Big Pressure Vesselg, ASMS Faper 67-MET-24.
} 


\begin{tabular}{|c|c|c|}
\hline & DIAM & IYPE \\
\hline a & $0.572-0.506$ & THFU \\
\hline b & C.502 & IHRU \\
\hline c & 0.502 & THRU \\
\hline d & 0.502 & THRU \\
\hline e & C. 500 & FBH 0.0005 \\
\hline$i$ & 0.500 & FBH C.3005 \\
\hline g & 0.500 & FB:A 0.003 \\
\hline$n$ & 0.500 & FBH 0.001 \\
\hline$i$ & 0.500 & ER!! 0.บU3 \\
\hline
\end{tabular}
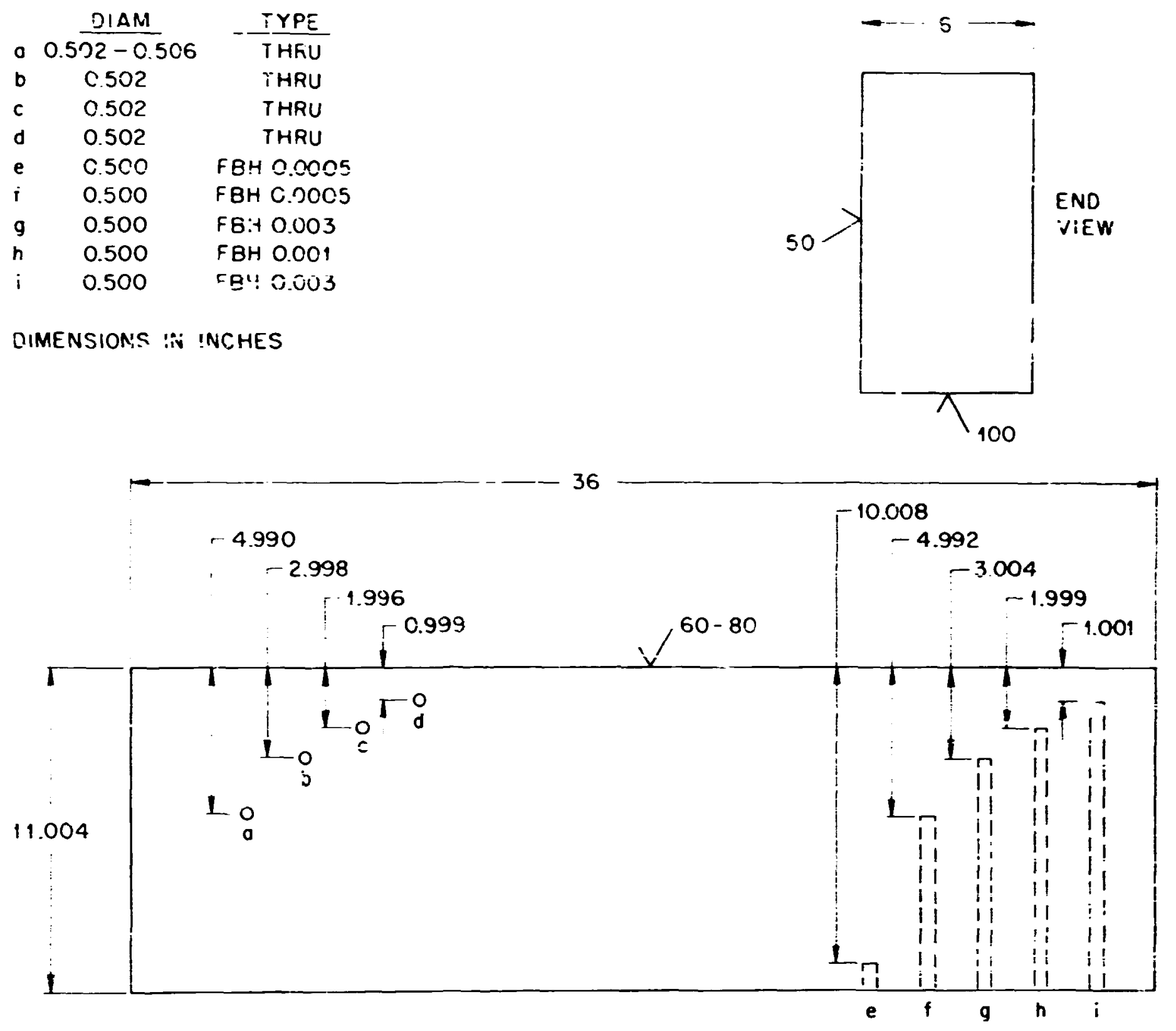

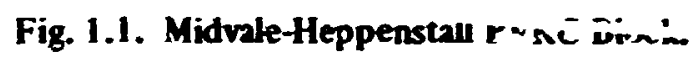

In general, calibration of the instrument for lungitudinal-wave inspection was performed as toilows:

1. Place the transducer directly over the flat-bottom hole that produced the highest-amplitude signal on the instrument screen.

2. Adjust the sensitivity to produce a signal amplitude of approximately $75 \%$ of full scale. Without changing the instrument settings, place the transducer over each of the other flat-bottom holes and plot the location and amplitude of the reflection from each hole on the instrument screen. This plotting results in a DAC curve.

3. Note and recurd the back-reflection amplitude with the transducer situated over a sound area on the reference block.

4. Move to the plate, riace the transducar over a sound area with a suitable surface preparation, and adjust the instrument sensitivity so that the amplitude of the first back refiection equals that receivec ficm the reference hlock. 
All discontimuities which caused a complete loss of back-surface reflection and/or produced signals with an amplitude equal to $m$ exceuing the height of the DAC curve were to be considered "recordable."

A DAC cu:ve for the loigitudina-wave inspection was plotted on the instrument screen from the following reak umplitude points:

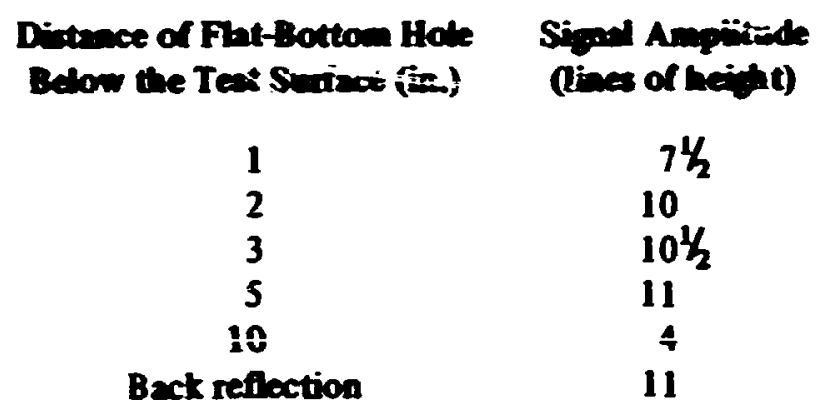

For this work, the usable screen height is 3 in. A grid superimposed on the screen is scaled 5 lines/in. Thus 15 lines is full screen height, and 12 lines is about $75 \%$ of full screen height. The longitudinal-wave DAC curve plotted from the above points is shown in Fig. 1.2.

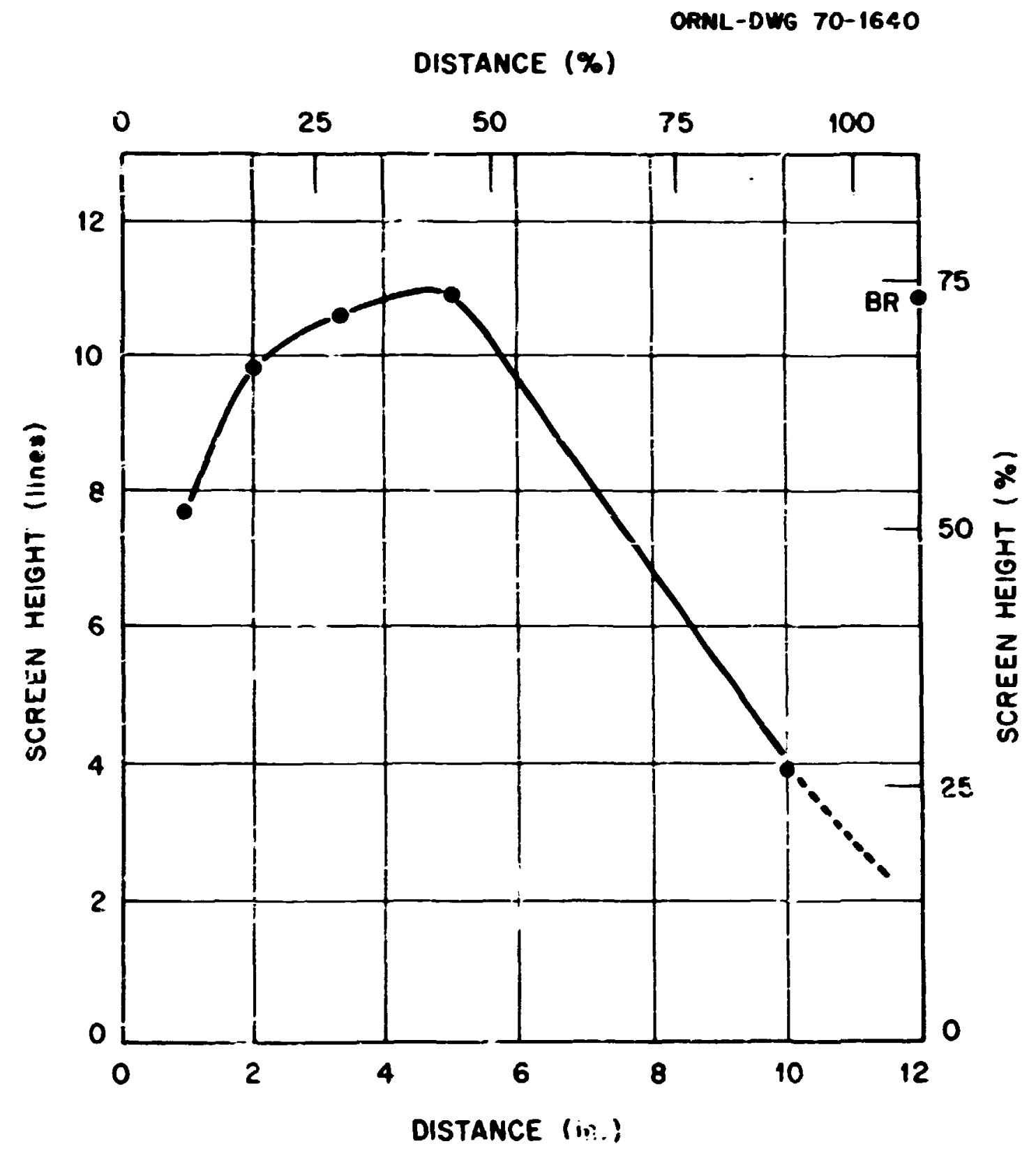

Pin 1.2. I omgitudian-Wre DAC Curve. 
Since the plate was in the as-rolled condition and tira reference biock in the quenc'sed and temperad condition, the attenuation pronerties of the two were dissimilar. When transierring the crystal from the riference black to the plate a loss of sensitivity was experienced. It became necessary to increase the s'nsitivity to maintain the back-reflection signai on the plate.

A grid system such as shown in Fig. 1.3 was scribed on the plated surface. The average surface finish of the plate was estimated to be 300 to $400 \mathrm{rms}$. Scanning of each 2 -ft square was completed before proceeding to the next square. The transducer was moved in paths parallel to the grid lines with an overlap of abjut $\mathrm{i} 0 \%$. However, no mechanical aids were used to assure the $10 \%$ overlap, merely the operator's perception. Three "recordable" longitudinal-wave indications were found during this inspection, and 'nese are shown in Fig. 1.3 denoted by the prefix LW.

\section{C.2 Shear-Wave Inspection}

Shear-wave inspection vas performed shortly after longitudinal-wave inspection was completed. The same test parameters applicable to the longitudinal-wave inspection are also applicable to this inspection except that a $1 \times 1$ in., $45^{\circ}, 1-\mathrm{MHz}$ crystal was used.

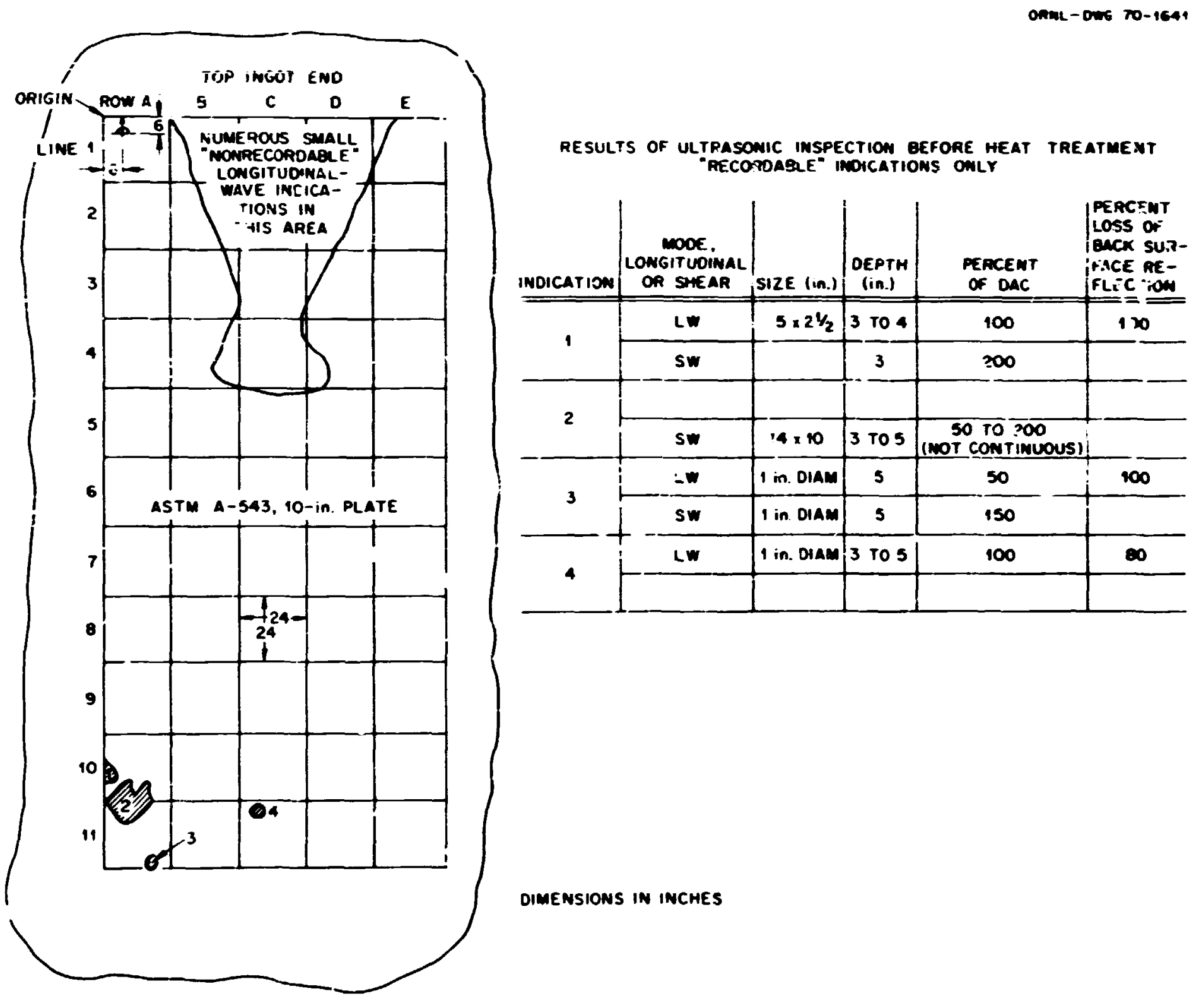

Fie. 1.3. Ultrasonic Indications Found During Finst Ultrasonic In pection. 


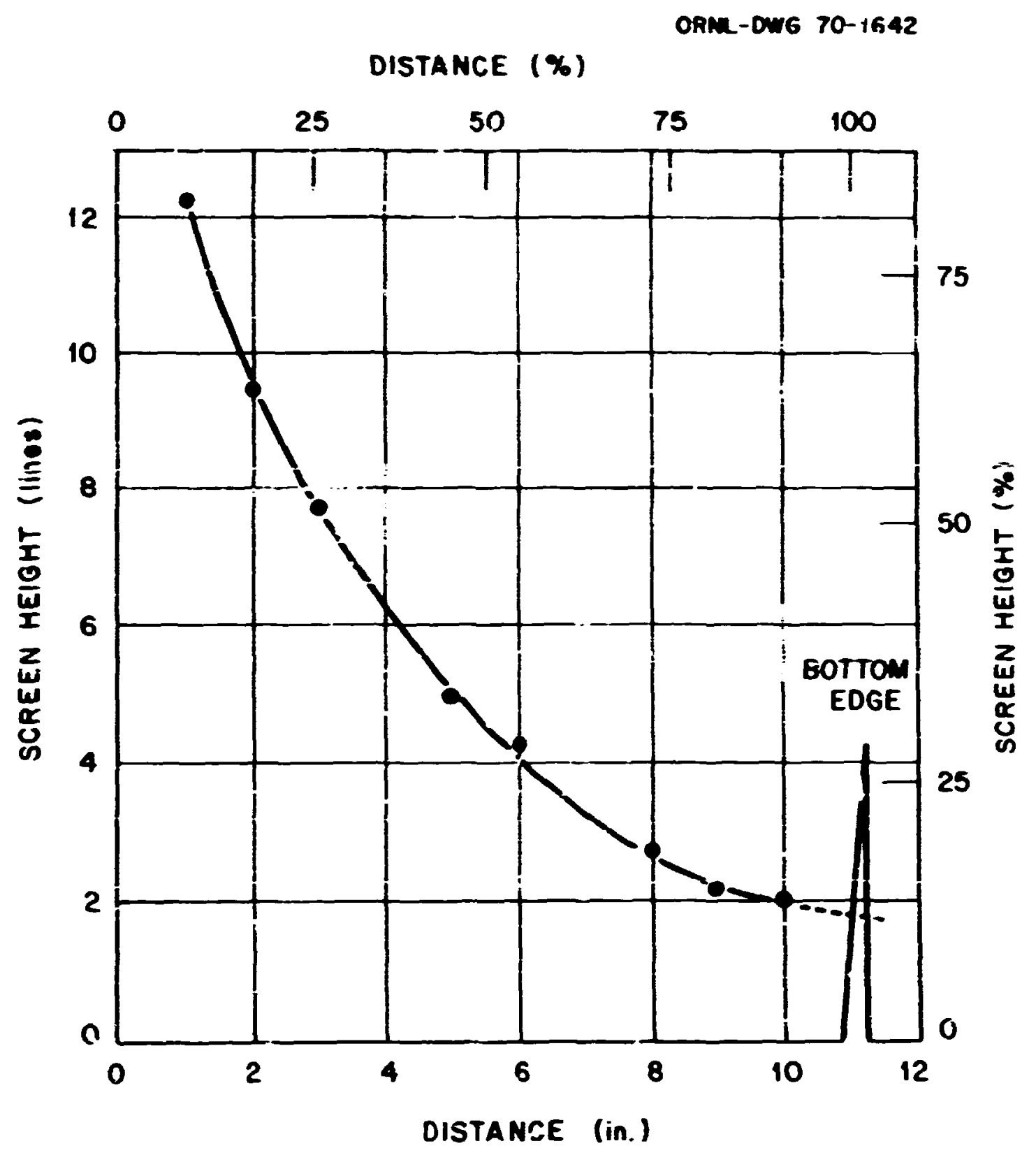

Fie ; A. Shar-Wwe DAC Curve.

Scanning from the top surface of the reference block, the reflected signals from the side-drilled holes were plotted on the instrument screen. The block was then inverted, and the points of peak amplitude from the side-drilled holes as viewed from the bottom side of ine reference block were plotted. A DAC cirve plotted from this calibration is stustst in Fit 1.4.

Three "recordable" shear-wave indications were found by this inspection, and these also are snown on Fie 1.3 .

\section{HEAT TREATME:T}

On completion of ultrasonic inspection a cutting plan delineating three separate plate patterns was scribed on the plate surface. Holes $1 / 4$ in. in diameter by $1 / 4$ in. deep were then drilled about 3 in. inside each pattern corner at both top and bottom surfaces. The locatica of these holes is shown in Fig. 1.5. The holes were used as reference points to determine the kngth, width, and diagonal dimensioril changes resuiting from the various heat treatments. Measurements were made before and after each heat treatment, and a tabuintion of the results is listed in part $G$ of this report. 


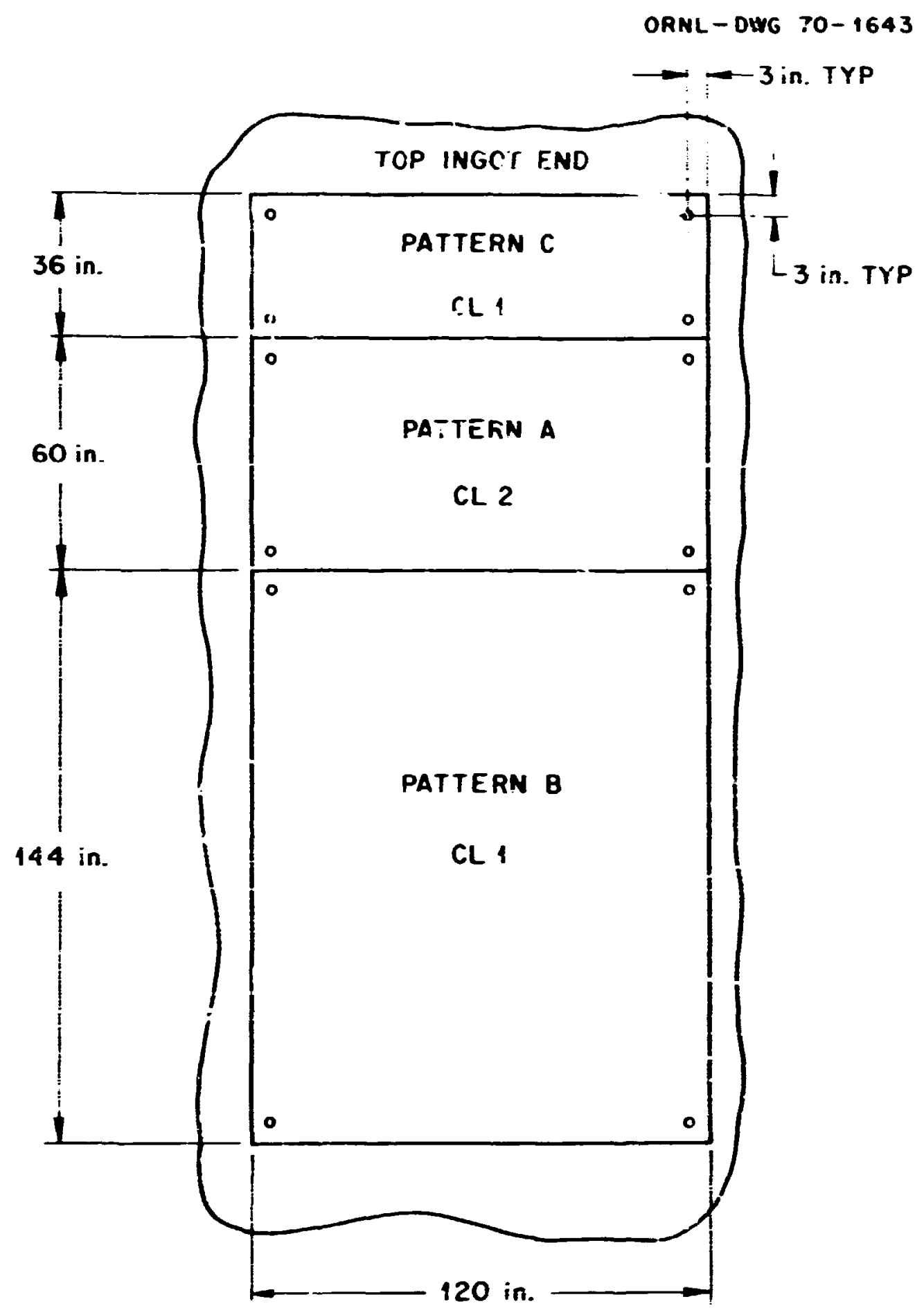

Fig. 1.5. Location of Dinesiond Reference I vints.

\section{1 Normalizing of the Fullsige Ptote}

Decensher 5,1968 , the plate was preheated to about $500^{\circ} \mathrm{F}$ and gas cut to the required width of 120 in., but the oversoll material at the iDF of pattern $\mathrm{C}$ and at the bottom of pattern $\mathrm{B}$ was left intact. Soon after cutting, the plate was chalged into furnace 4 at 8:15 PM for normalizing. The plate was oriented in the fumace as shown in Fig. 1.6. Ten hours later the furnace thermocouple readings had stabilized within the normalizing range of $1725 \pm 25^{\circ} \mathrm{F}$, anj a $10 \mathrm{hr}$ hold period was begun. On completion of the hold period, the plate was withdrawn from the furnace and air-cooled. The spread in thermocouple readings during the heatup and hold periods is shown in Fig. 1.: Since the plate was air cooled and no thermocouples were attached to the plate, cooling rate data are not available. 


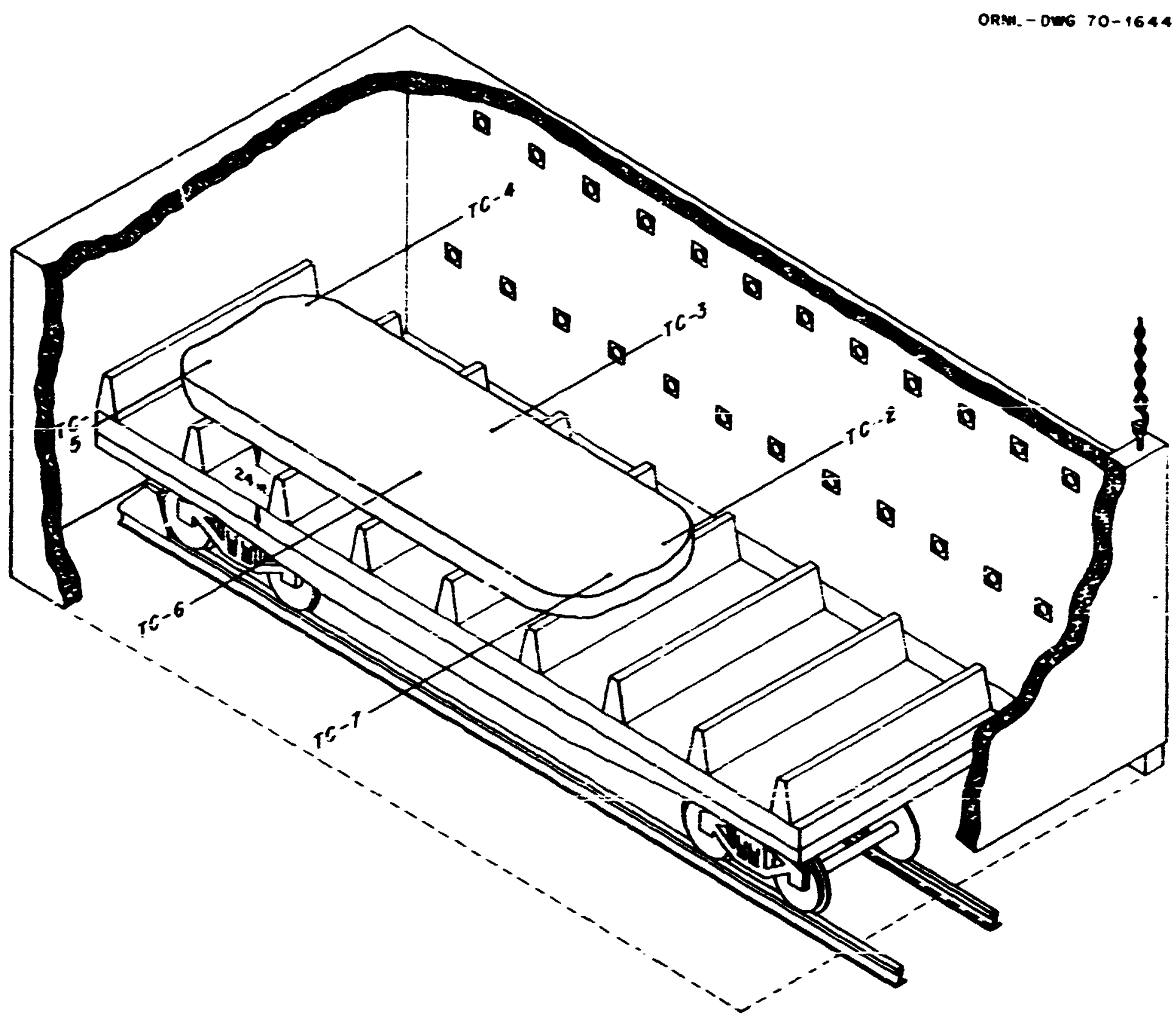

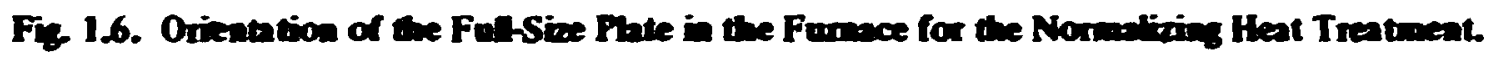

\section{D.2 A ustenitizing and rewehing of the Fullsize Phate}

A few days prior to the austenitizing heat treatment, the plute was equipped with six stainless-steelsheathed t; fa K Chromel-Alumel therriocouples mounted in Honeywell type $P$ measuring junctions. The stainless-steel-sheathed couples were used from the hot junction points to about 5 ft outside the furnace; asbestos therr locouples were used from this point to the recorder. A typical thermocouple installation is shown in Fig. 1.8.

The plate was later psintec with a "freescaling" paint. About 1:30 PM on December 22, 1968, the piaie was laid on a fumace car asci placed in furnace 2 as sinown in Fig. 1.8. Some $51 / 2$ hr later the plate-attached thermocosiples vere recosding within the austenitizing range, and a $71 / 2-h r$ hold period was started. Througinoust the hold period the spread in thermocouple readings, shown in Fig 1.9, remained almost constant at $1650 \pm 10^{\circ} \mathrm{F}$.

The furnare door was opened about 2:30 AM the following morning. The time lapse between opening the door and completely immersing the plate was $1 \mathrm{~min} 40 \mathrm{sec}$. The plate was lifted for quenching in the flat position with a lifting device called a "peel," which consisted of several rectangular-shaped steel 


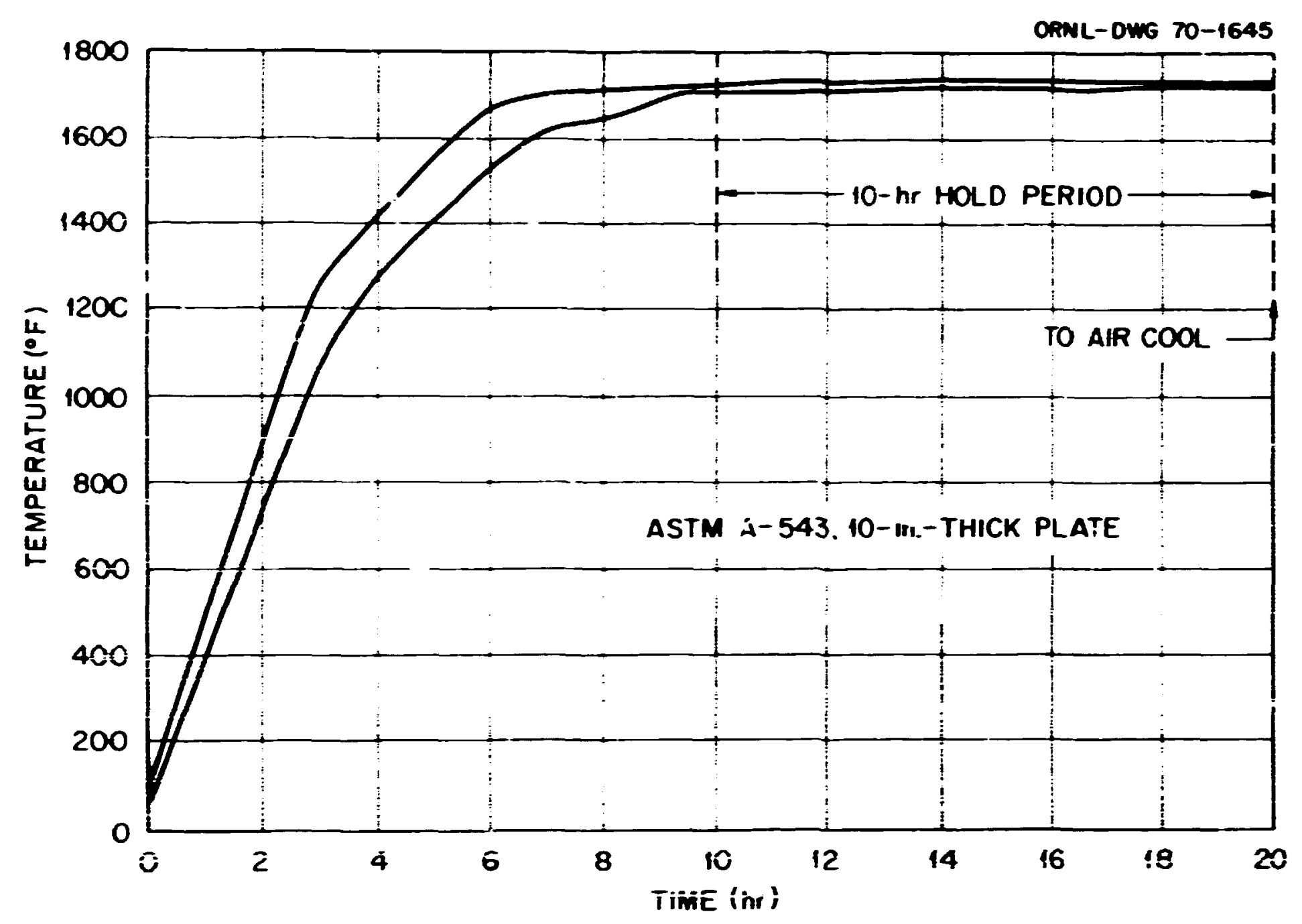

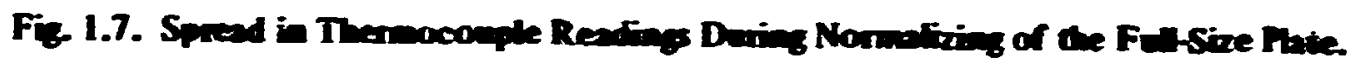

members, open on one side, suspended from an overhead crane. The steet blocks on wirch tine pinte was supported on the fumace car (see Fig. 1.8) were sepaiated to sermit the rectangular members to be inserted between them and under the plate.

Lukens' quench tank measursd about $20 \times 60 \times 8 \mathrm{ft}$ deep. Agitation of the quench medium was provided by high-pressure 8 -in. water inlet piping.

The plate remained in the water for $1 \mathrm{hr}$, at which tims the highest thermocouple reading was $260^{\circ} \mathrm{F}$. Water temperatures recorded during the quench are as follows:

$\begin{aligned} \text { Prior to quench } & 83^{\circ} \\ \text { Quench at 2:37 } & 83^{\circ} \\ 2: 42 & 94^{\circ} \\ 2: 50 & 97.5^{\circ} \\ 2: 53 & 39^{\circ} \\ 3: 03 & 94^{\circ} \\ 3: 15 & 91^{\circ} \\ 3: 30 & 86^{\circ}\end{aligned}$

Figure 1.10 shows the cooling rates for the six plate-attached thermoccuples. As was experienced in previous flat quenchings of HSST plates, the top surface couple cooled faster than thuse located on the bottom surface. It is suspected that steam entrapment resulting in reduced circulation on the ivitorn itus was a contributing factor in causing this. The couples embedded it midthicisness cooled at practically the same rate, even though one was situated $15 \mathrm{j}$ in. from an edge and allother near the midwidth. The same also applies to the ccuples located at $1 / 4 \mathrm{~T}$. 


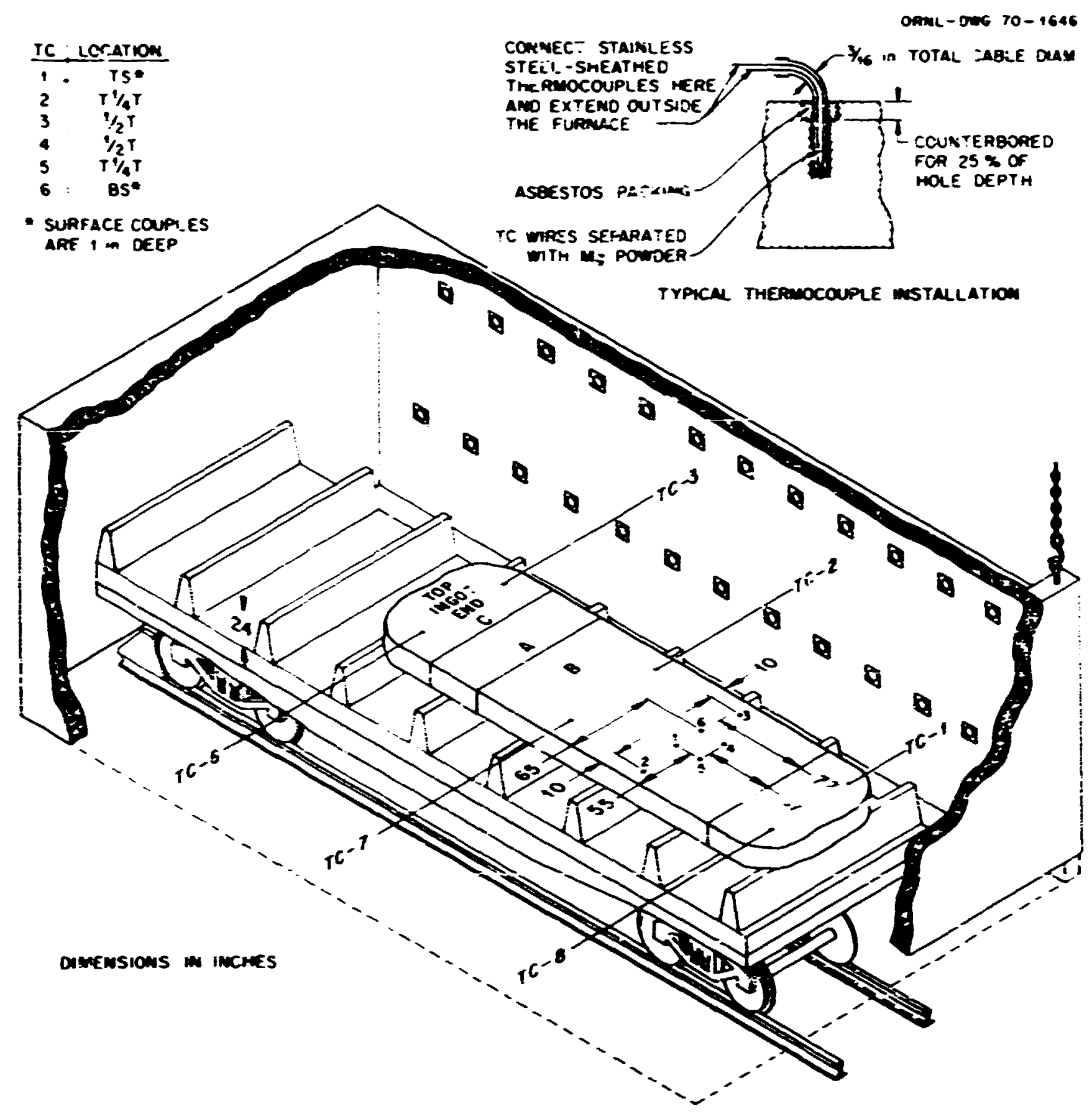

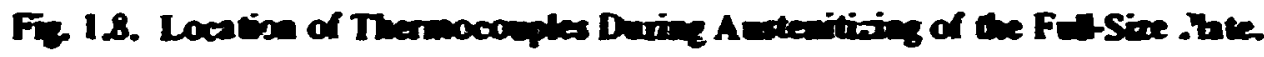

\section{D.3 Tempering of the Fulsize Pate}

Soon after the plate was withdrawn from the gianch medium, the plate-attached thermocouples were removed. While the quenching operation was in progress the furnace door was allowed : $s$ reirain open and all firing units were stiut off. In this manner the furnace was relatively cool when the plate was recharged for tempering.

The plate occupied essertialiy the same position in tise furnace during this treat treatment as during the austenitizing heat treatment. The furnace was refired a.0cut 5:00 PM. About 2:00 AM the tempering temperature expected to prodice ciass 1 properties was achieved. Figure 1.11 shows the spread in thermocoliple readings throughout the $19 \mathrm{hr}$ heati $\mathrm{g}$ and holding periods. On completion of the prescribed 10-hr hold period, the plate was withidrawn from ths surnace and air cooled to ambient temperature.

After the full-size plate was tempared, the plaic ass preheated to about $500^{\circ} \mathrm{F}$ and pattern $\mathrm{C}$ was gas cut from the remaining portion of the plate. Following cutting, the two plate segments were placed in 


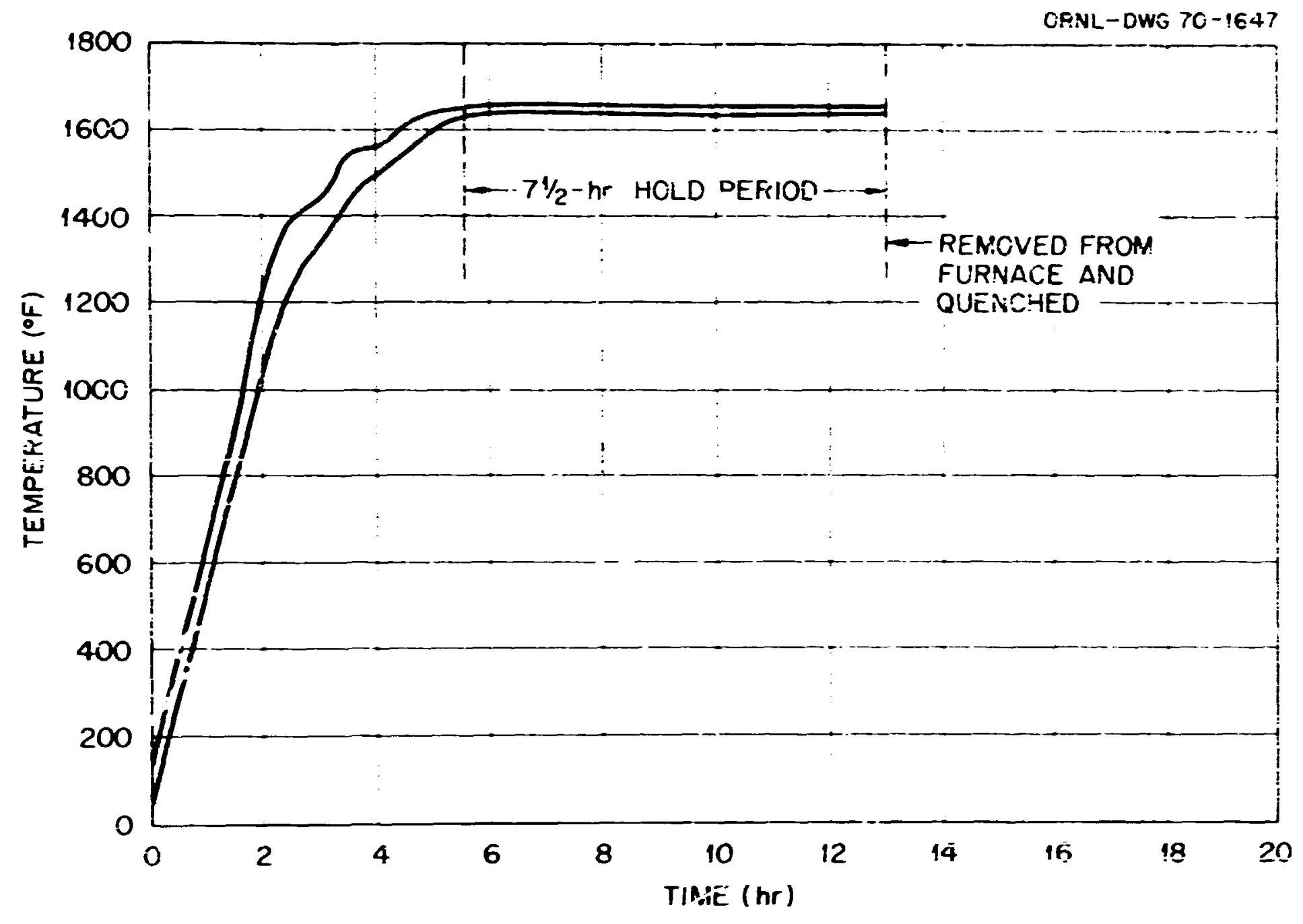

Fiz 1.9. Spread in Twemoconple Reading Rering Arstenitizing of the Fullsine Phate.

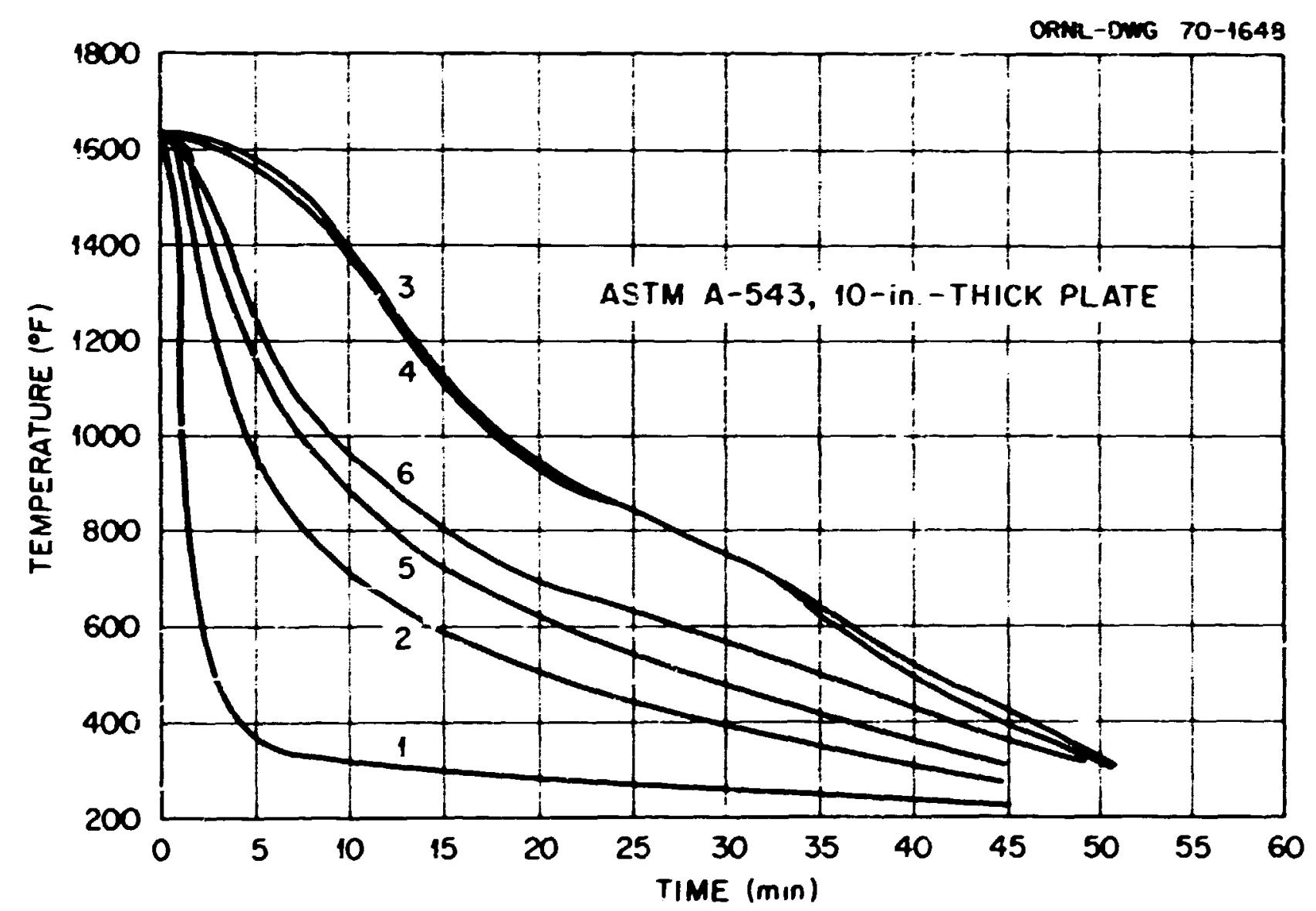

Fiz 1.10. Cooting Curves for the Six Fate-Attzched Thermocouples During Quenching of the Full-Size Plate. 


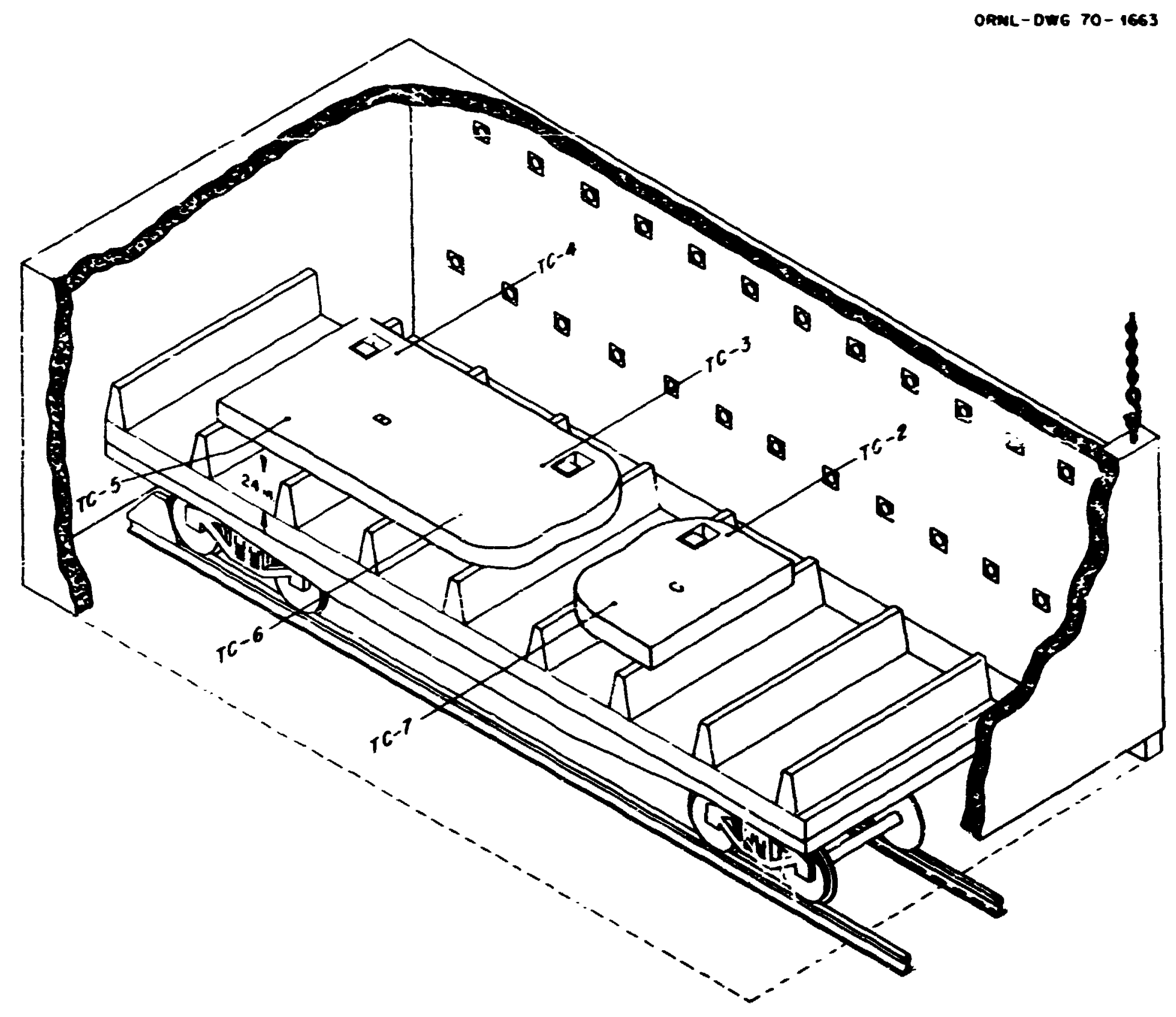

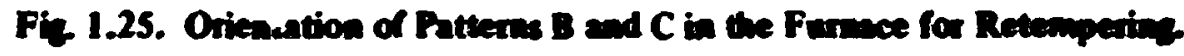




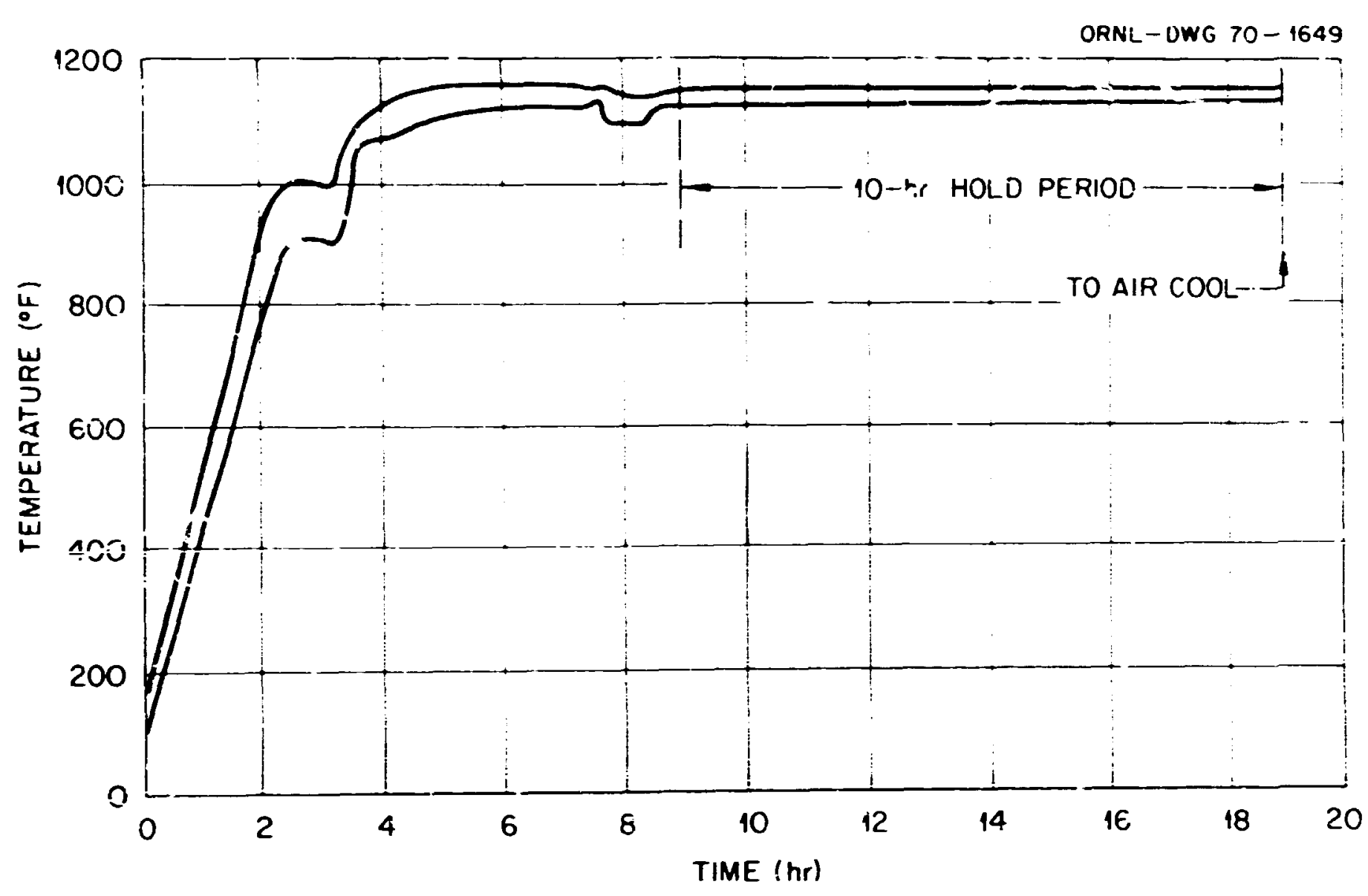

Fig 1.11. Spread in Thermocouple Reading Dunisan Tempering of the Full-Size Plate.

furnace 7, as shown in Fig. 1.12, and stress relieved at $1050^{\circ} \mathrm{F}$ for $4 \mathrm{hr}$. The spread in thermocouple readings for this charge is shown in Fig. 1.13. Both cutting and heat treatments were performed on January $7,1969$.

\section{D.4 Reaustenitizing and Quenching of Patterns A and B}

The original thermocouple holes, in the segment of plate containing patterns $A$ and $B$, were reamed to ciear : neiai, zad the thermucoupies were reinstalled. Again the plate material was painted with a "free-scaling" paint frio: to heat treatment. After drying, the plate segment was recharged into furnace 2 , as showa in Fig. 1.14, o:1 January 13.

The furnace was fired abcut 7:00 PM. About $4 \frac{1 / 2}{2}$ hr later the highest plate-attached thermocouple reading was within the prescribed austeniticing temperature of $1575 \pm 25^{\circ} \mathrm{F}$, and a $71 / 2 \cdot h r$ hoid period was started. The temperature readines stayed weil within the intended limits, as shown in Fig. 1.i.5, throughout the hold period.

On completion of the hold period the plate segment was withdrawn from the furnece and ouenched. The cooling ciisves for the plate-attached t/lermocouples are shown in Fig. 1.16.

\section{5 Retempering of Pattems $A$ and $B$}

Soon after the plate segmeni was reinoved from the quench tank, the plate-attached thermocouples were removed. The plate segment was recharged ato furnace 2 about 6:00 AM on January 14, 1969, and the material was situated on the furnace car ds shown in Fig. 1.17. Following a 5-hr heatup period, the furnace ternperature was maintained at $1100 \pm 25^{\circ} \mathrm{F}$ for $10 \mathrm{hr}$ in an effort to achieve class 2 mechanical 


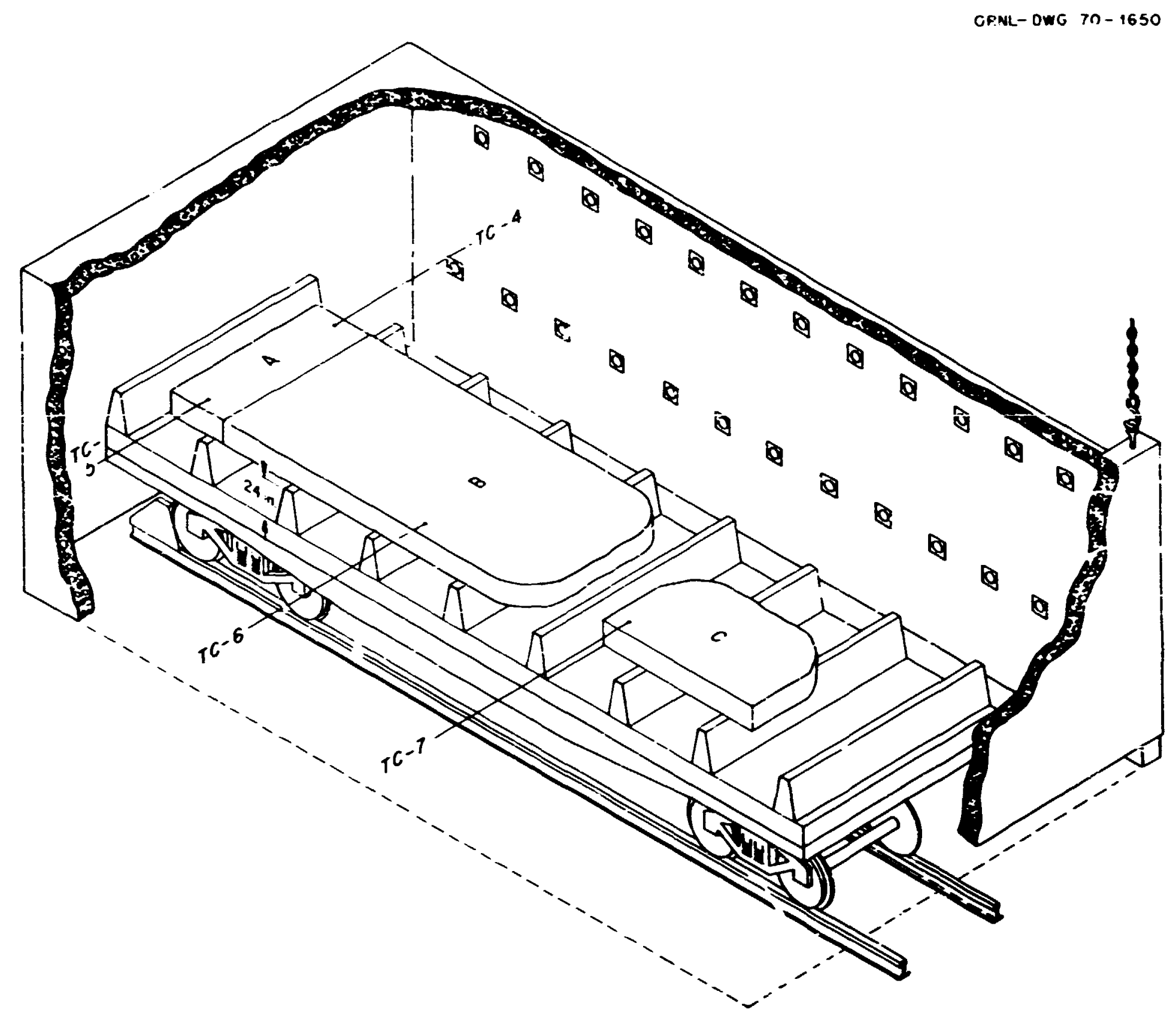

Fig- 1.12. Orientation of Pattems A-B and $C$ in the Stress-Relieving Furmace.

properties (see Fig. 1.18). On completion of the hold period, the material was taken from the furnace and cooled in air to ambient temperature.

The plate segment containing patterns $A$ and $B$ was then preheater to absut $500^{\circ} \mathrm{F}$, and the two patterns were separated by gas cutting.

\section{D.6 Third Tempering of Pattern B}

At this stage in the history of the plate, pattern B has been double austeritized and tempered, first to class 1 properties (with full-size plate) and then to class 2 properties while stiached tu pattern A. On February 8, 1969, pattern B was reivaded on a furnace car, as shown in Fig. 1.19, and placed in furnace 4 for a thi, 1 tempering operation to change it from class 2 back to class 1 mechanical properties. Curves showing the spread in thermocouple readings for this operation are showin in Fig. 1.20. Pattern B was water quenched following the tempering heat treatment. 


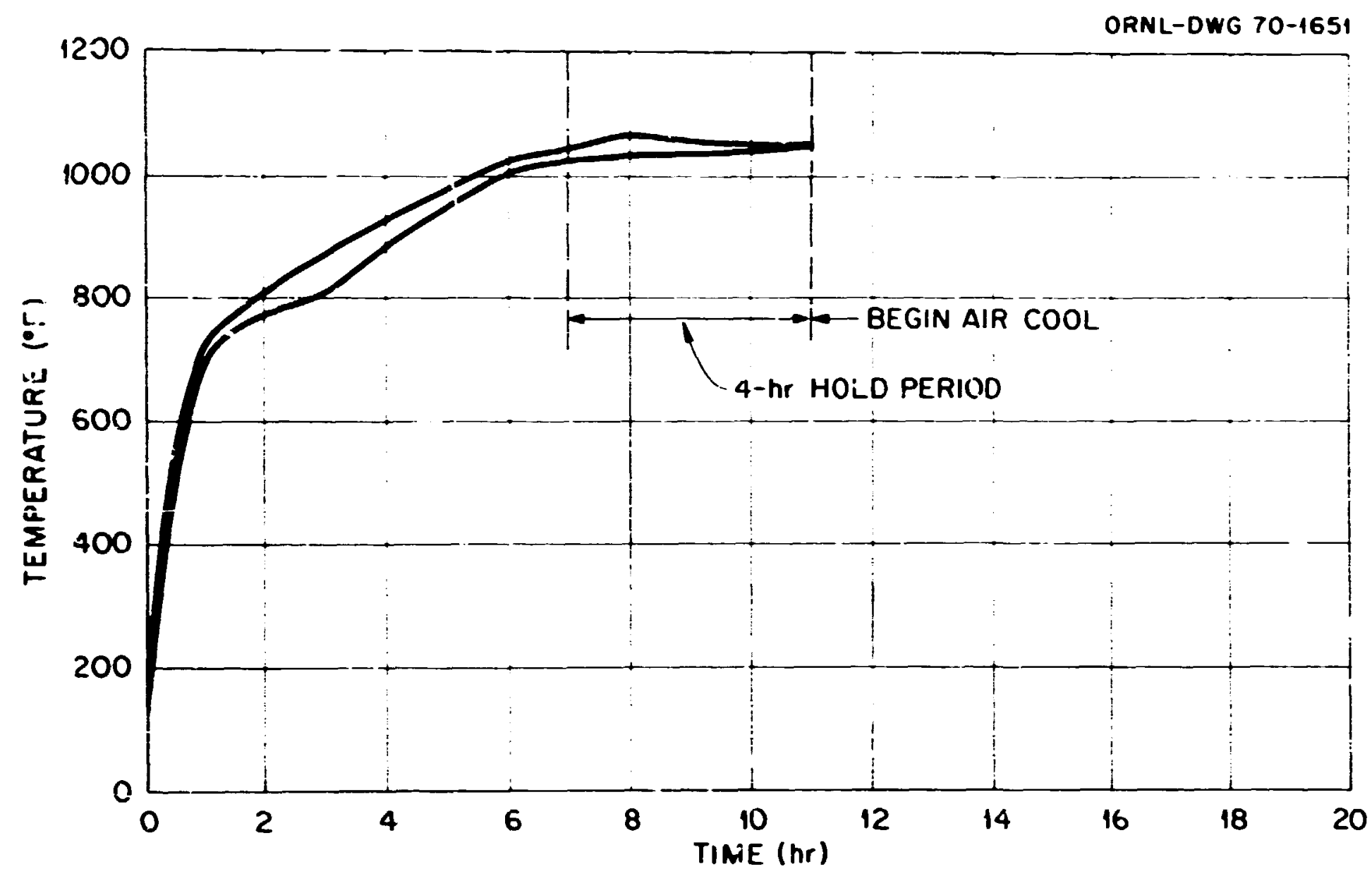

Fis. 1.13. Spread in Thermocouple Reading During the Stren-Relievirg Heat Trentment After Separatiog Pattern C from A-B.

\section{D.7 Streas Retieving of Patterns A, B, and C}

Each of the three plate segments was loaded on a furmace car the iollowing day and charged into furnace 4. The position that each occupied in the furance is essentially as shown in Fig. 1.21. The furnace was fired off aboint 1:00 PM on Febnuary 9. After some $11 \mathrm{hr}$ of heating, the furnace ccuples were rezording temperalures in the range cf $1050 \pm 25^{\circ} \mathrm{F}$, and the 50-hr hold period was started. The prescribed temperature was rasintained throughout the hold period (see Fig. i.22). On completion of the hold period, the patterns were furnace cooled to below $6000^{\circ} \mathrm{F}$, removed fron: the furnace, and air cooled to ambient temperature.

\section{D.8 Strese Relieving of Patterms A, B, and C after Removal of Teat Material}

Each rattern was preht?:ed to about $500^{\circ} \mathrm{F}$, and the material for plate qualification testing was removed from the locations shuwn in Fig- 1.23. On removal of the test material, the patterns and the test cutouts were phiced in furiace 3 ior a 4 hr stress relief. The location of the materials in the furnace and the curves shuwing the stress relief data are shown in Fis. 1.23 and 1.24 respectively

\section{D.9 Retempering of Patterms A, B, and C after Mechanical Texting}

Lukens reported that the mechanical testing performed at this time indicated that the patterns were tempered at roo low a temperatilie to prodice the specified tensile preperties. Accordingly, the remaining lest material was retumed to the original sutout slots and secured by tack welding. The pcsition occupied 


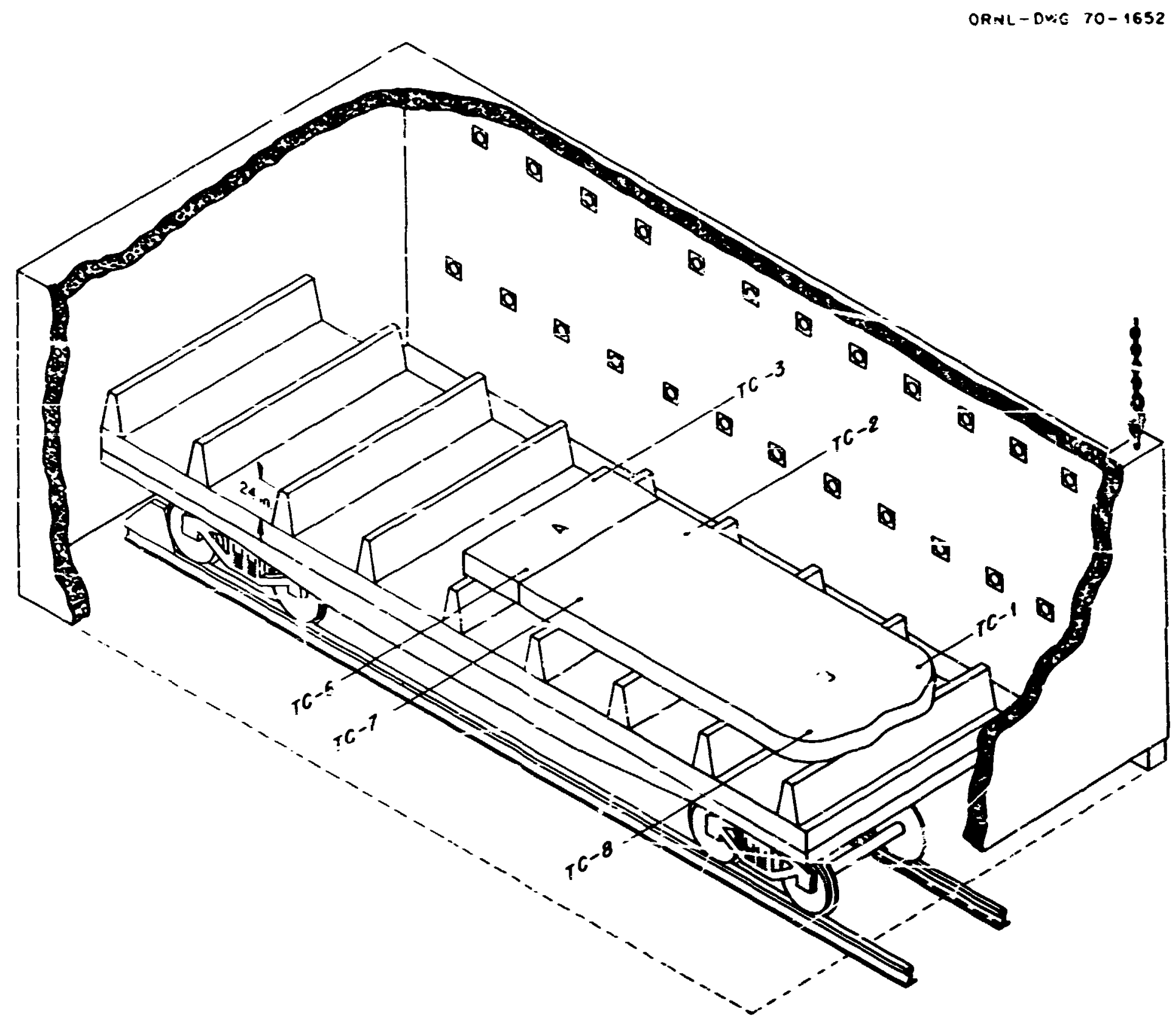

Fie 1.14. Orientation of Patterns A and B During the Reaustenitiving Heat Trentmeat.

by patterns $B$ and $C$ in the furmace is shown in Fig. 1.25; pattern $A$ is shown in Fig. 1.26. Each was heat treated in fumice 4.

Patterns $B$ and $C$ were heated to $1180 \div 15^{\circ} \mathrm{F}$ and held at temperature for $10 \mathrm{hr}$ and furnace cooled. The heating, holding, and cooling dat for this charge ars shown in Fig. 1.27.

Pattern $A$ was heated to $1140 \pm 15^{\circ} \mathrm{F}$ and held for $10 \mathrm{hr}$ and air cooled. Only the temperatures during the hold period and the cooling data are available for this charge; the'; are shown in Fig. 1.28. This work was completed on March 26, 1969. 


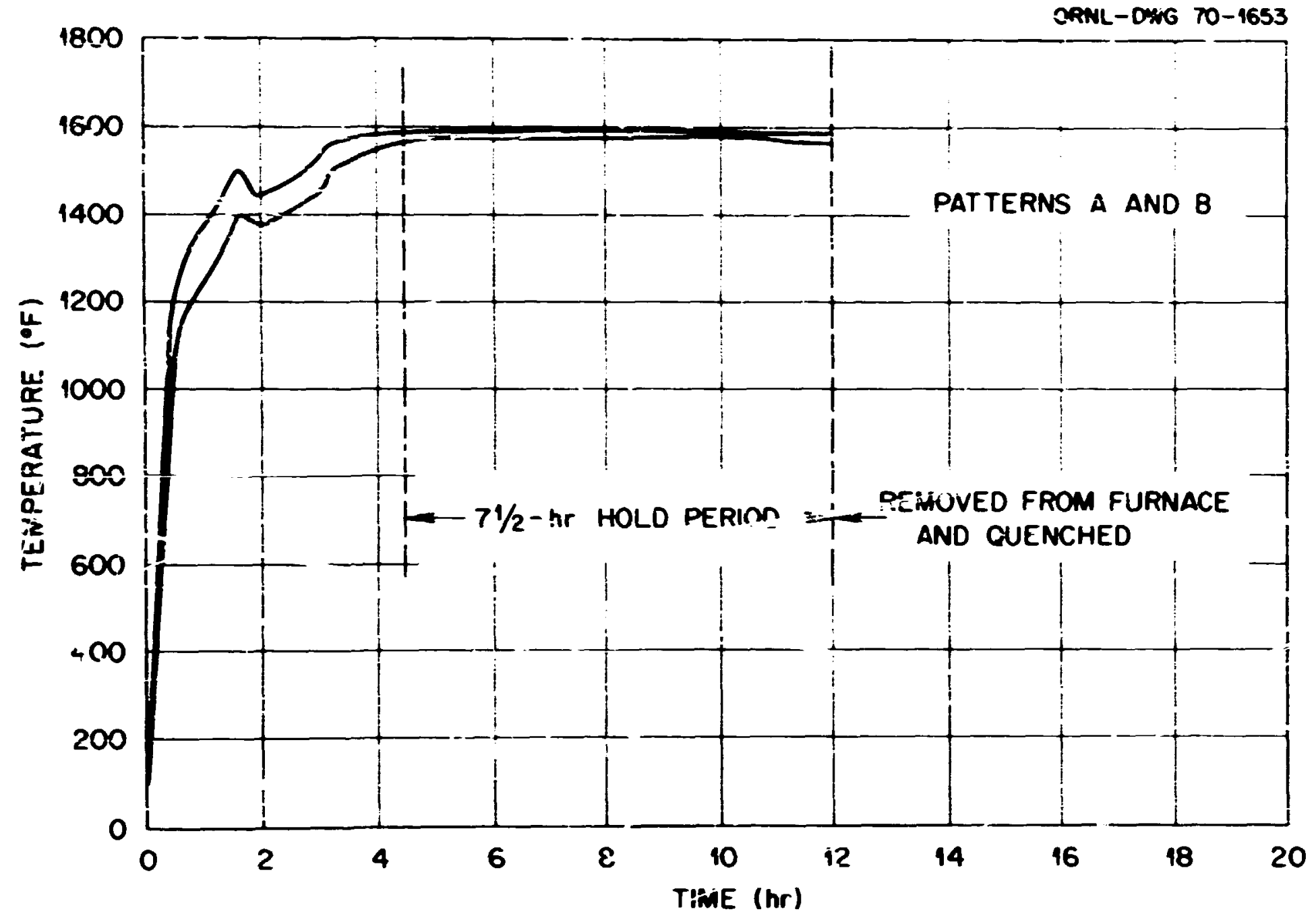

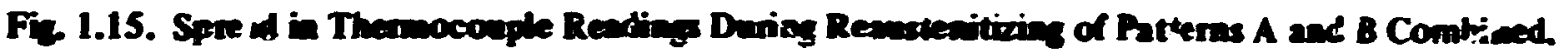

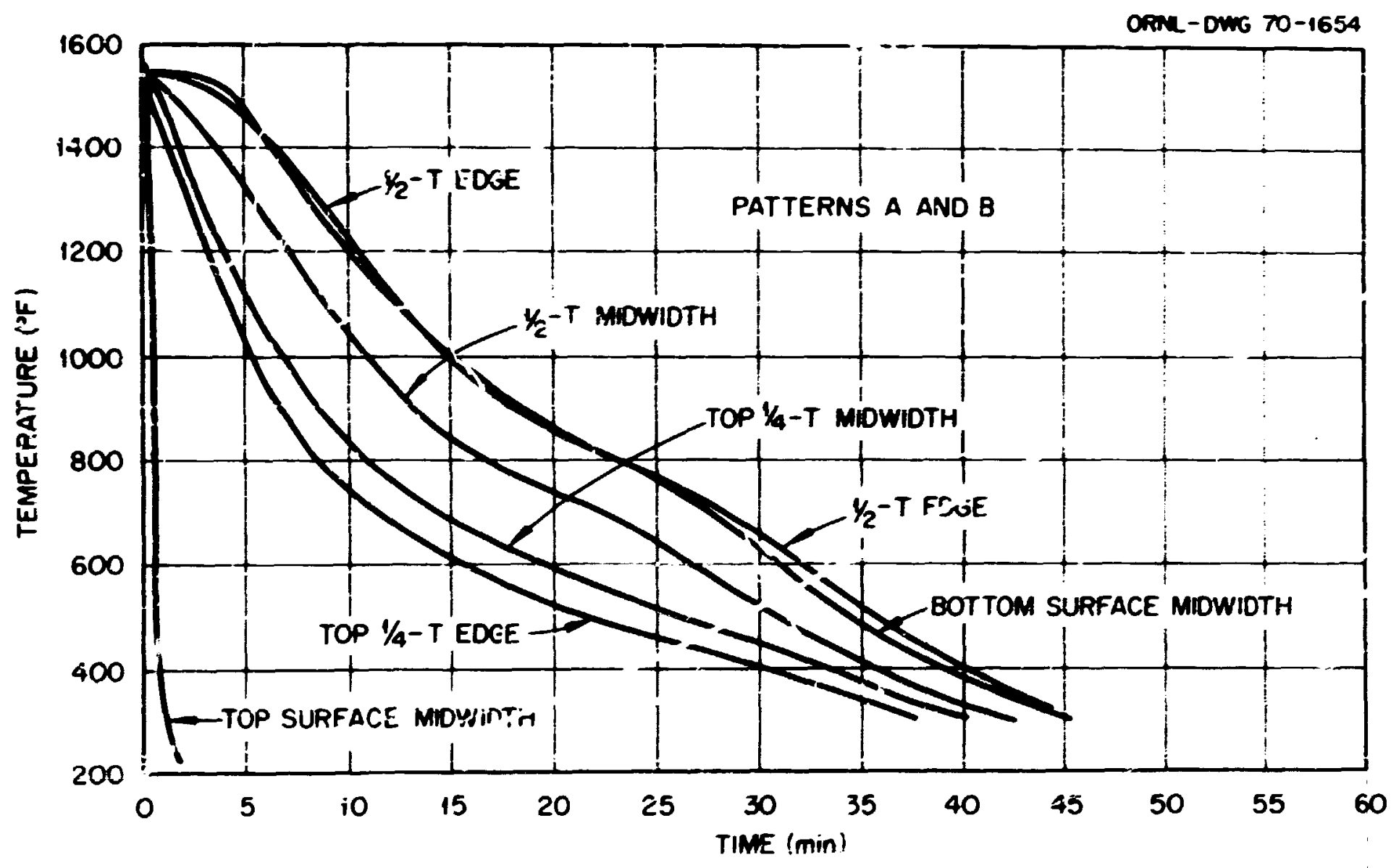

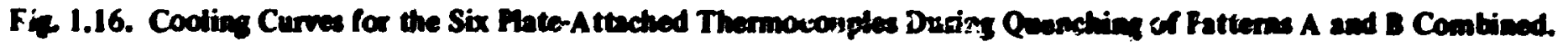




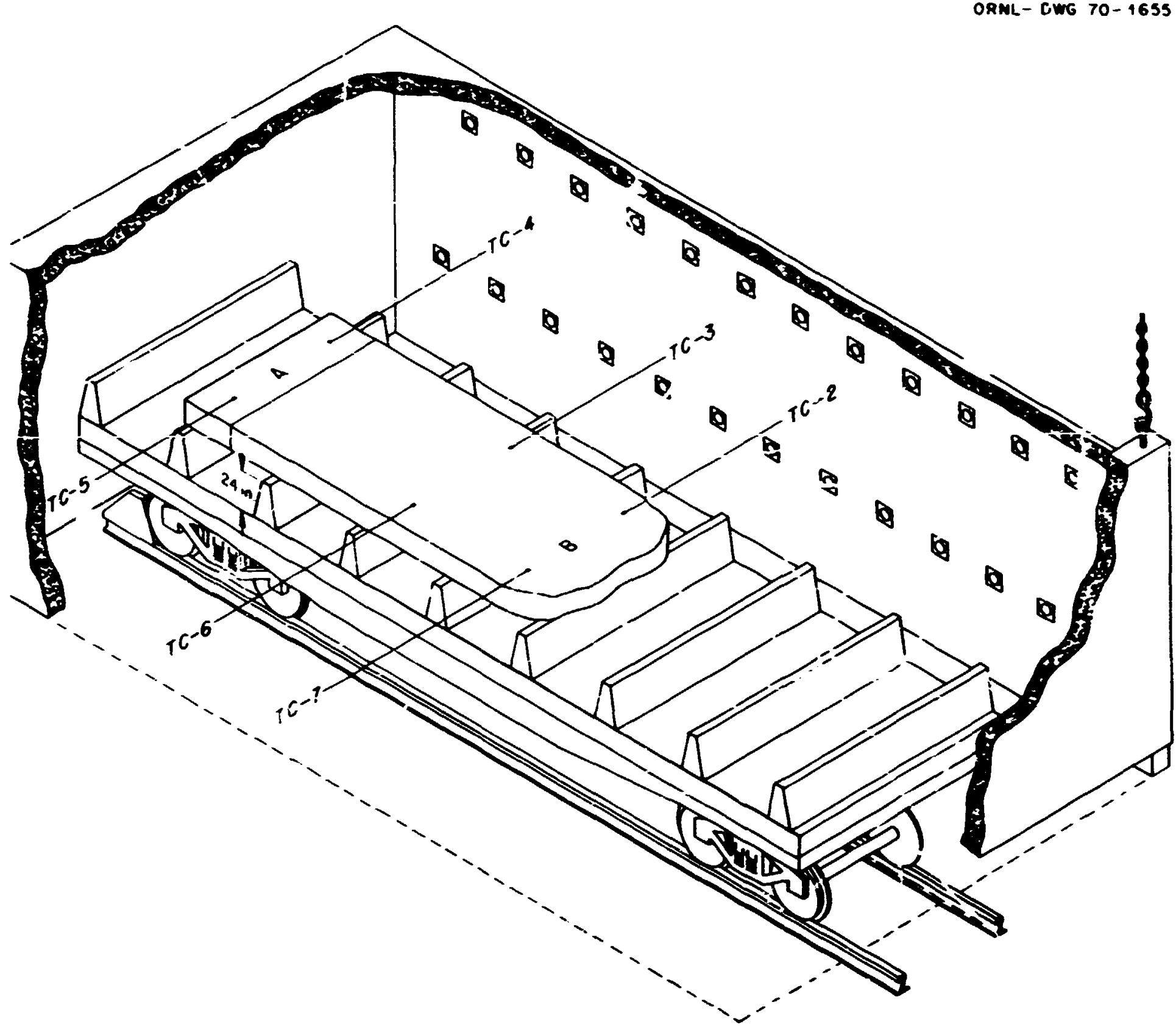

Fiz 1.17. Orientution CI Patters A and B in the Funace for Retemperies.

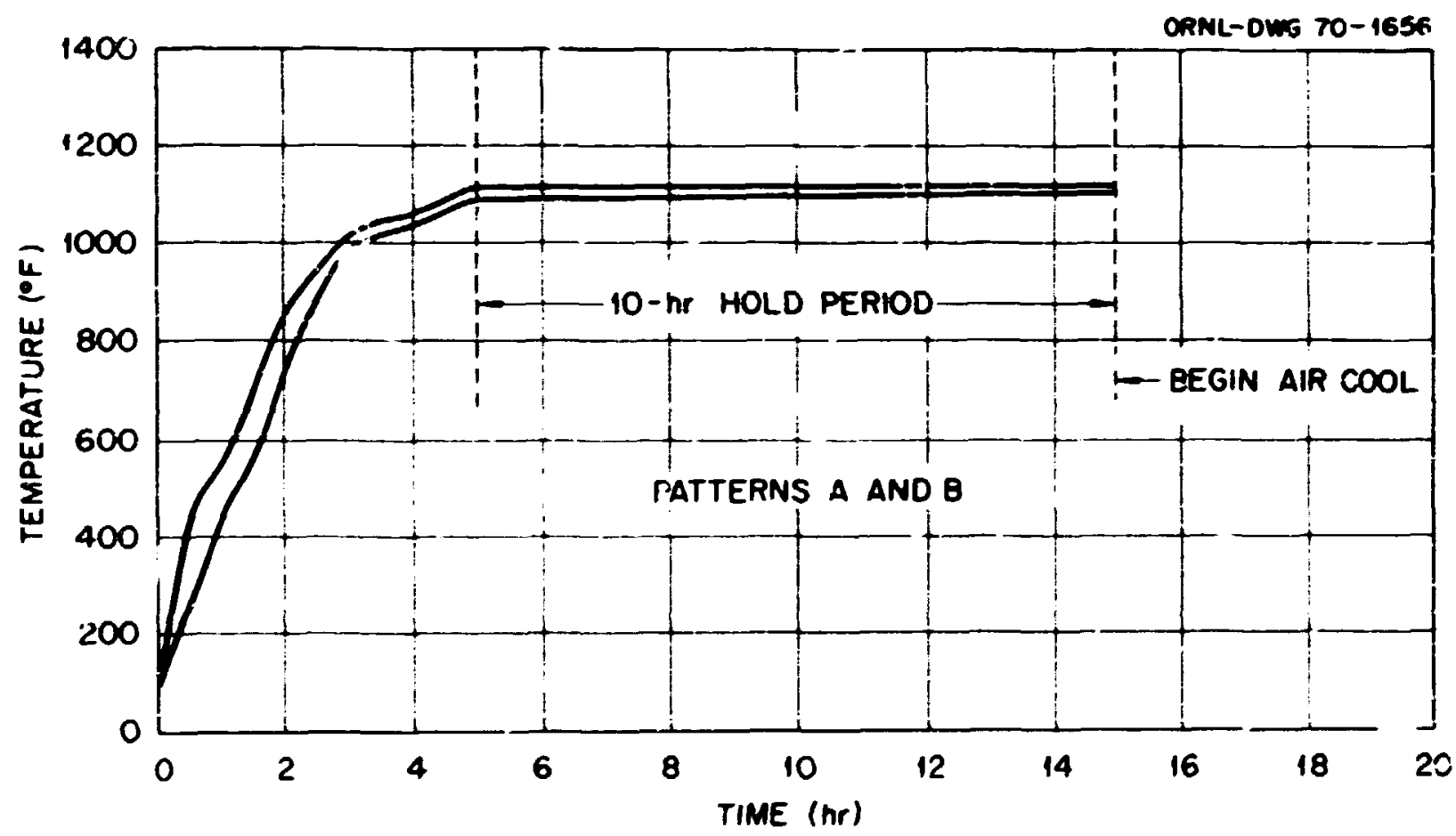

Fig. 1.18. Spread in Thermoch uple Readings Durige Retempering of Patterns A and B Combined. 


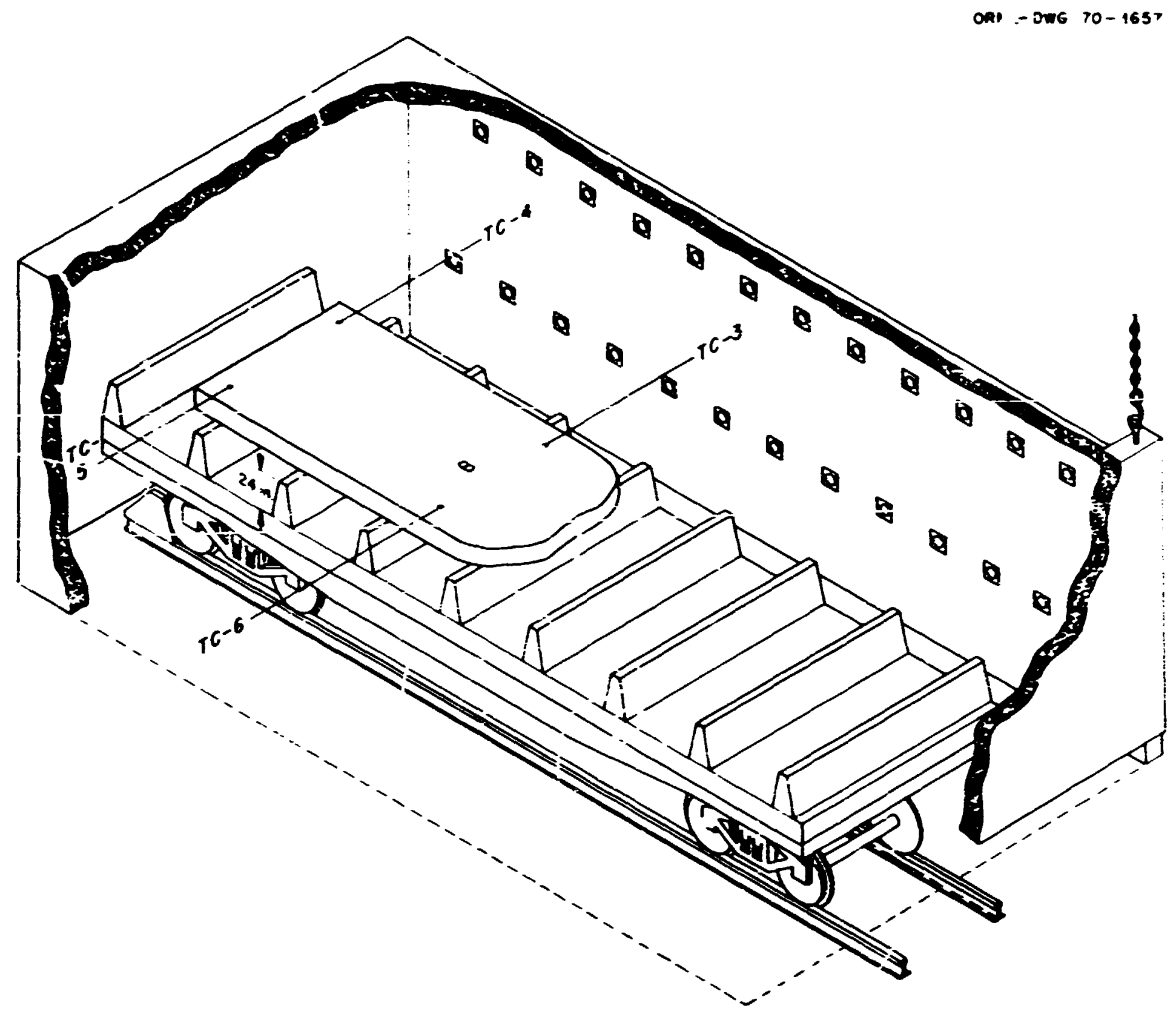

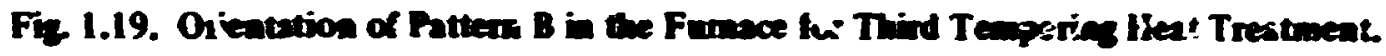

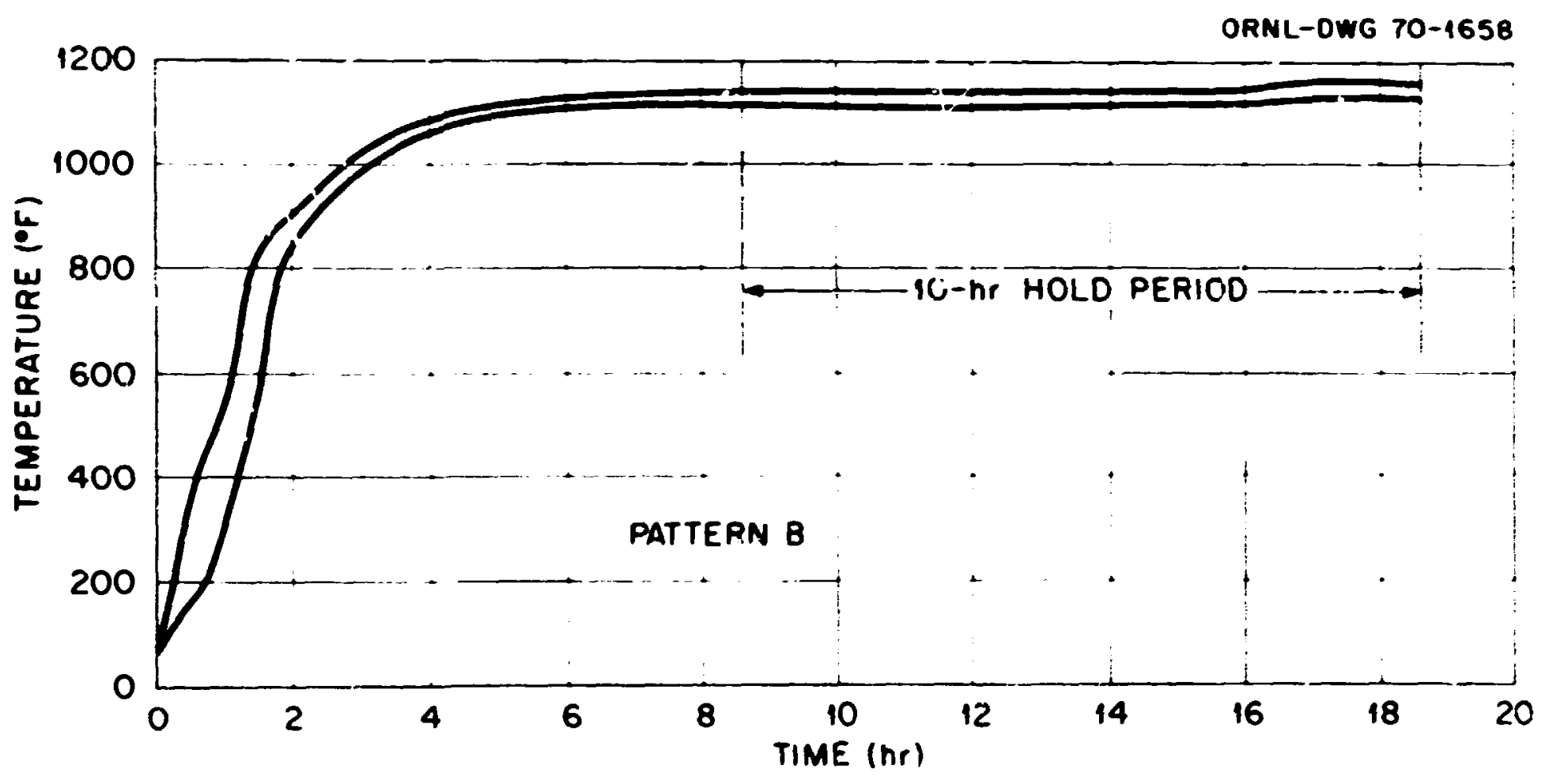

Fiz 1.20. Spread is Murmoconple Reading Darias Third Tempering of Mattem B. 


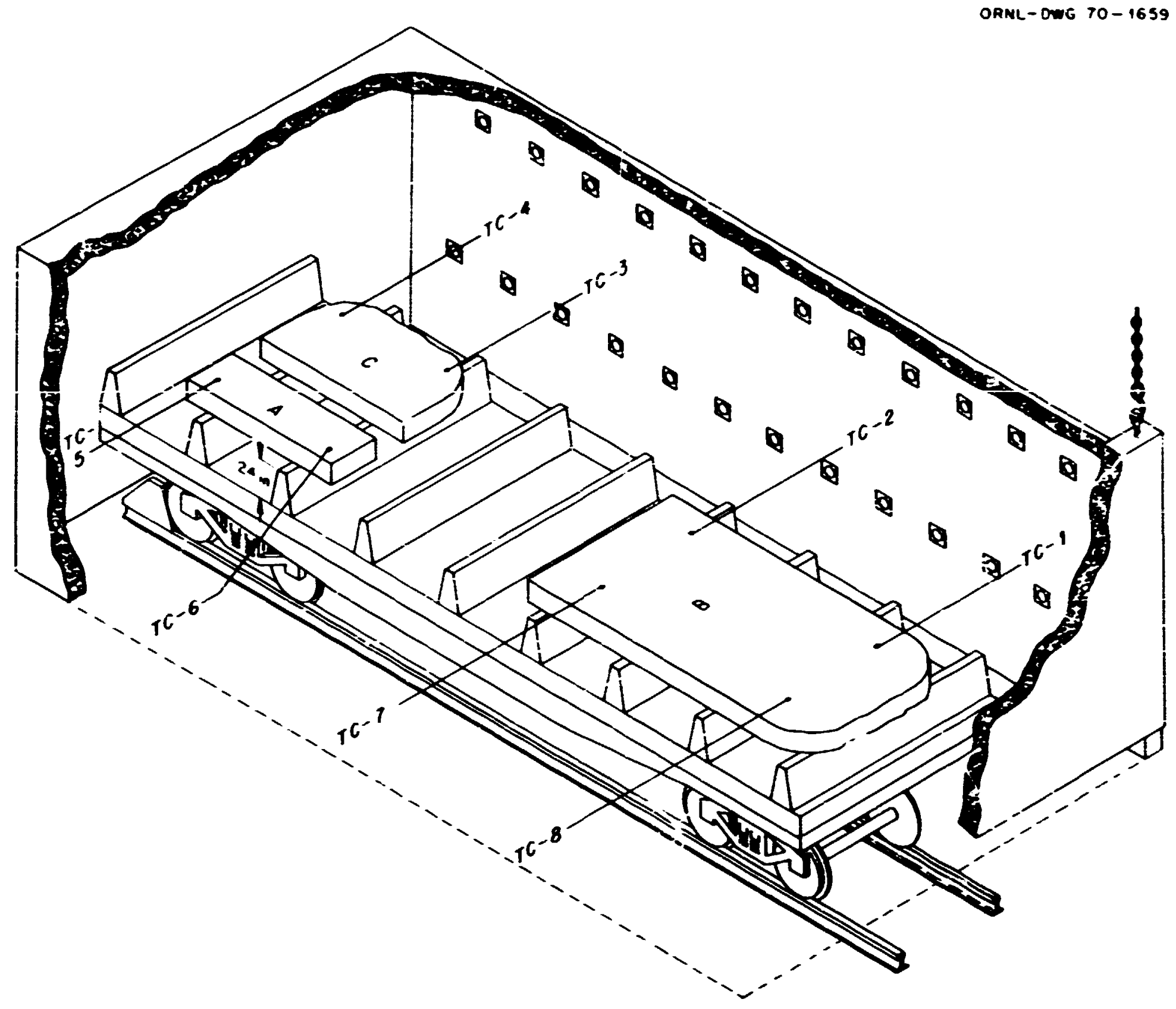

Fiz 1.21. Criemtation of Potteren A, B, and C in the Furnace for Strea Relieving.

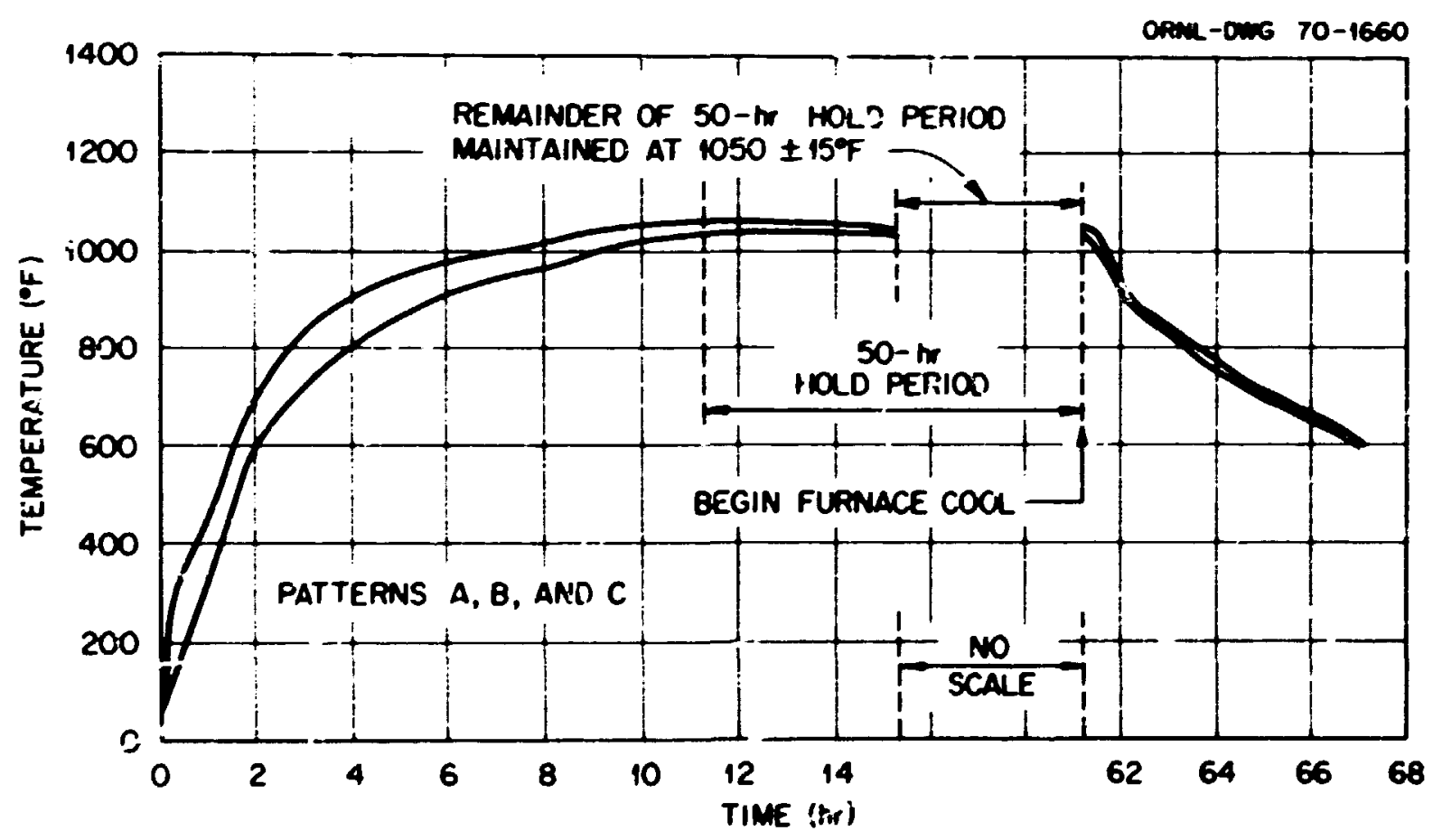

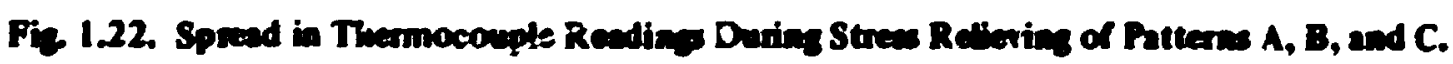




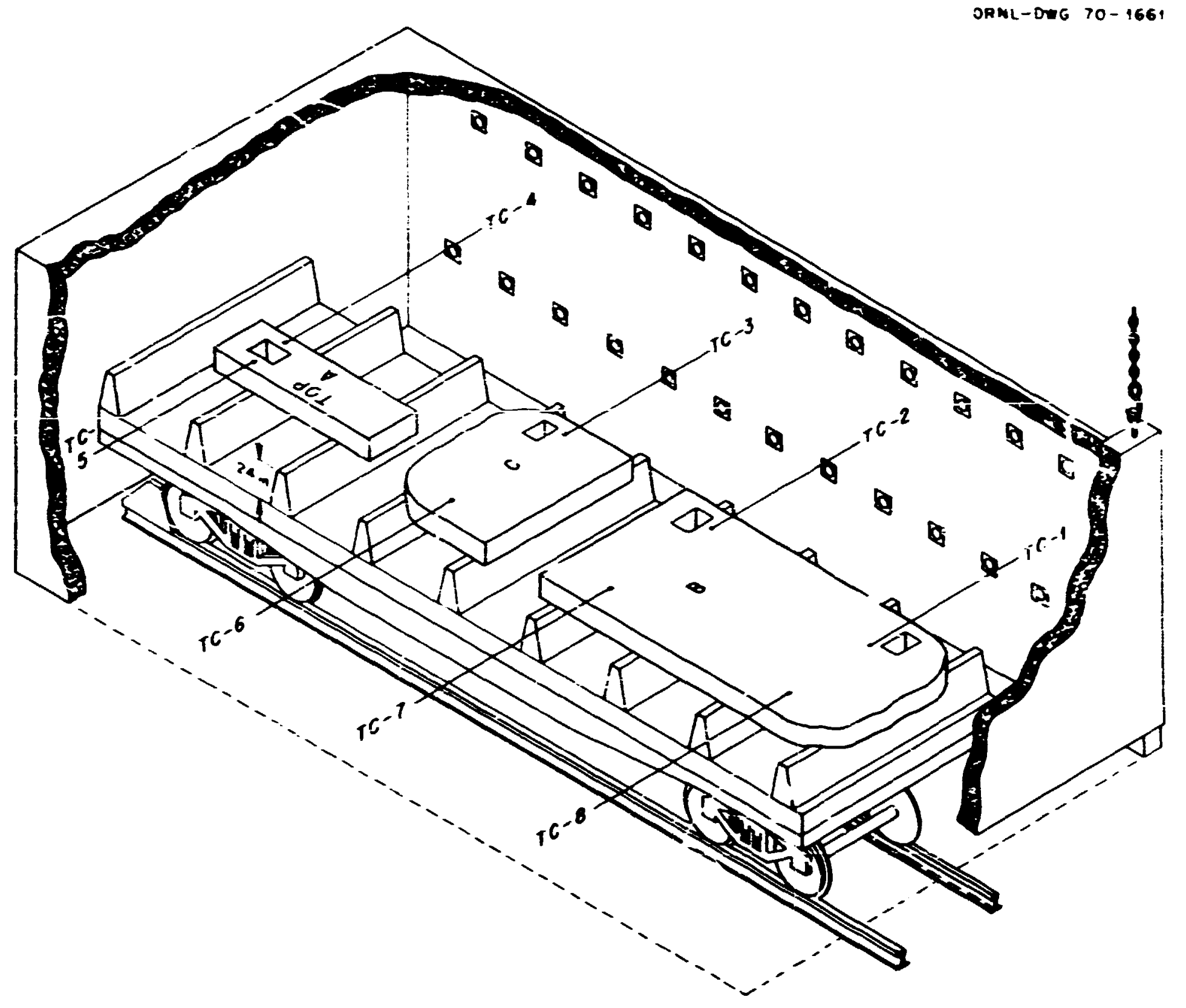

Fin 1.23. Orientation of Patters A, B, and C in the Funace for Streas Relief After Removel of Tear Material.

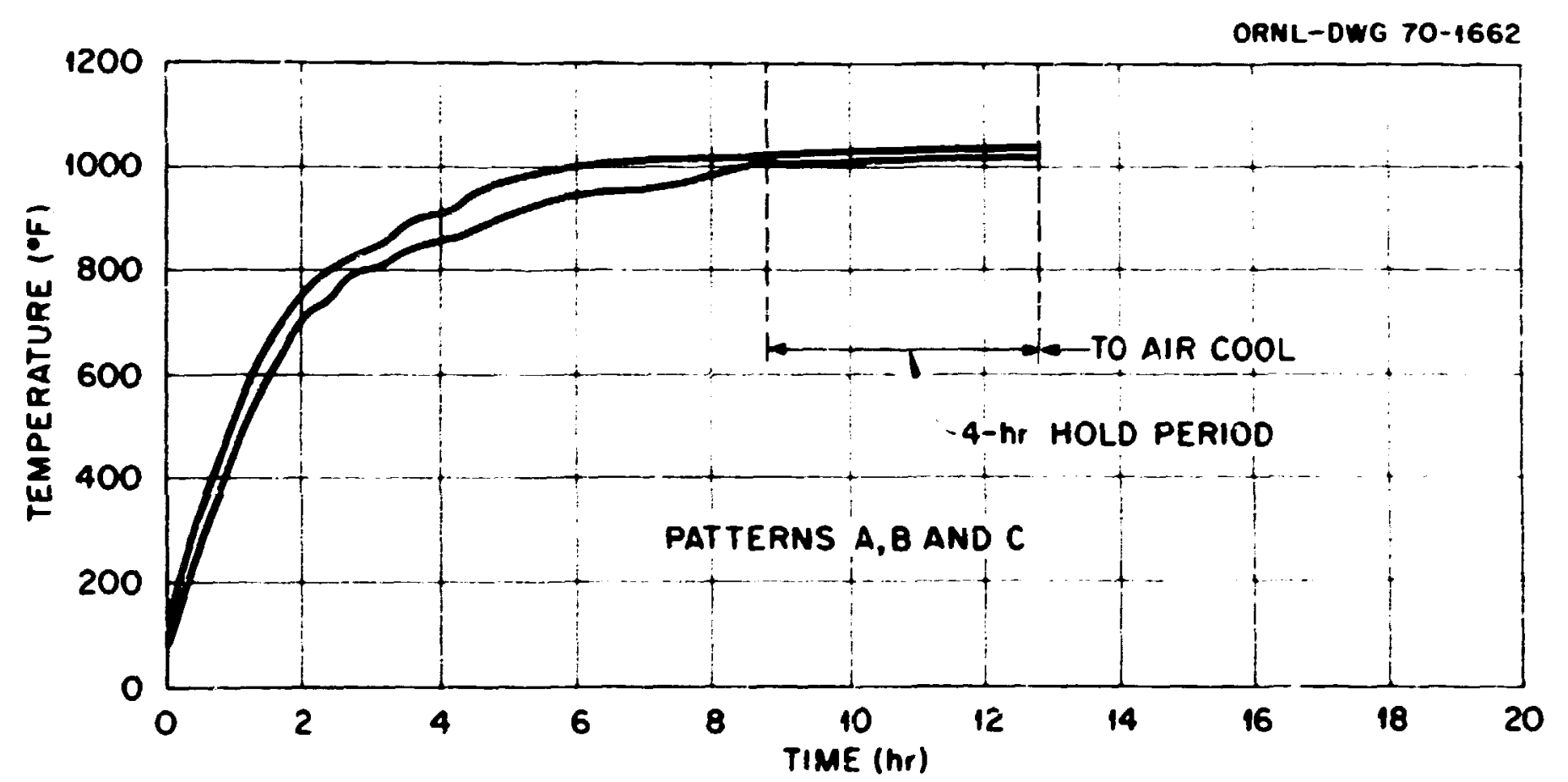

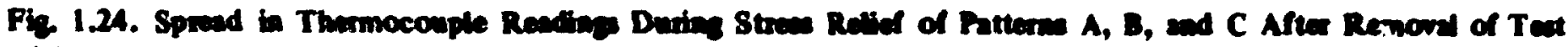
Material. 


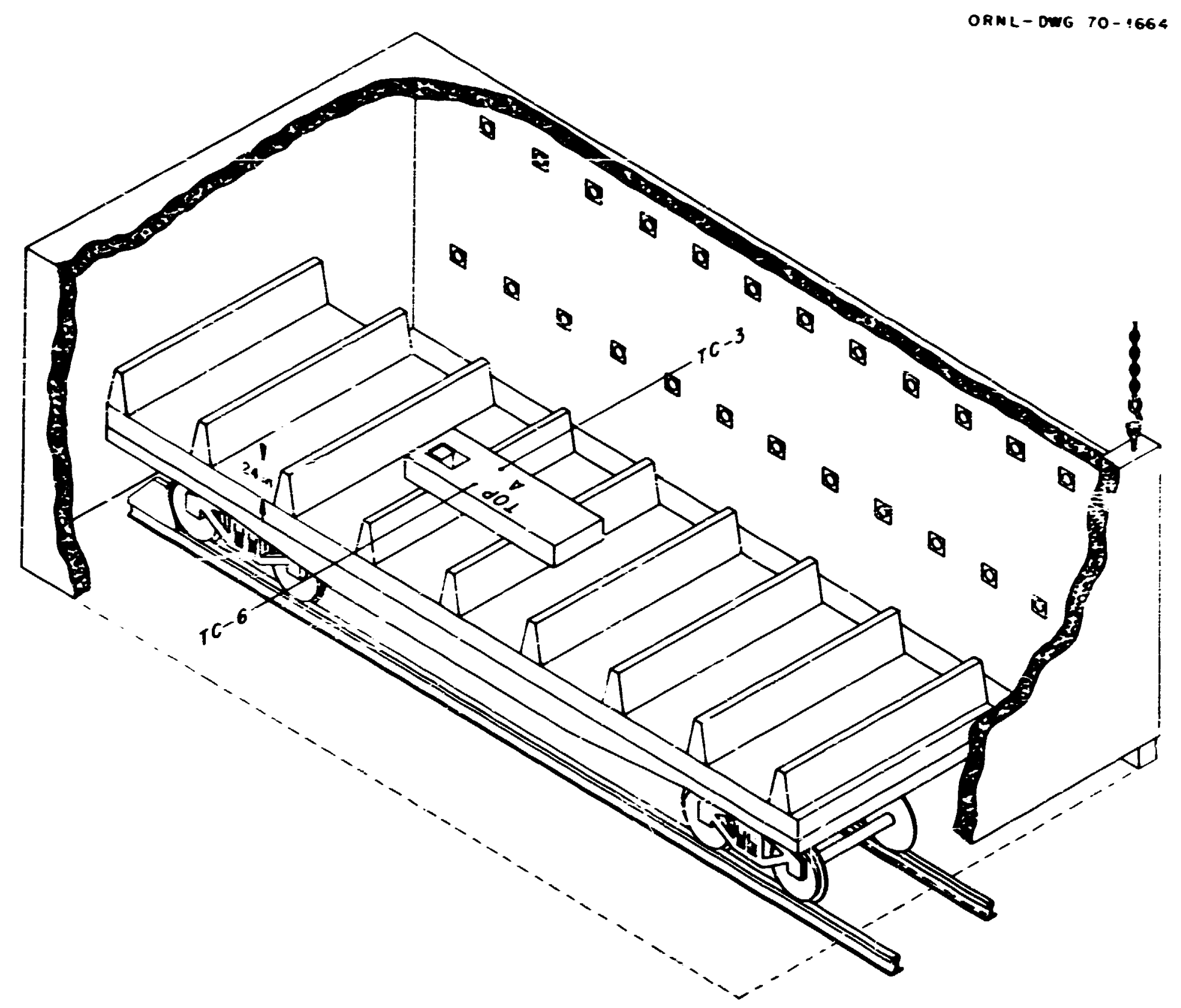

Fie 1.26. Orientation of Pattern A in the Furnace for R-temperinge. 


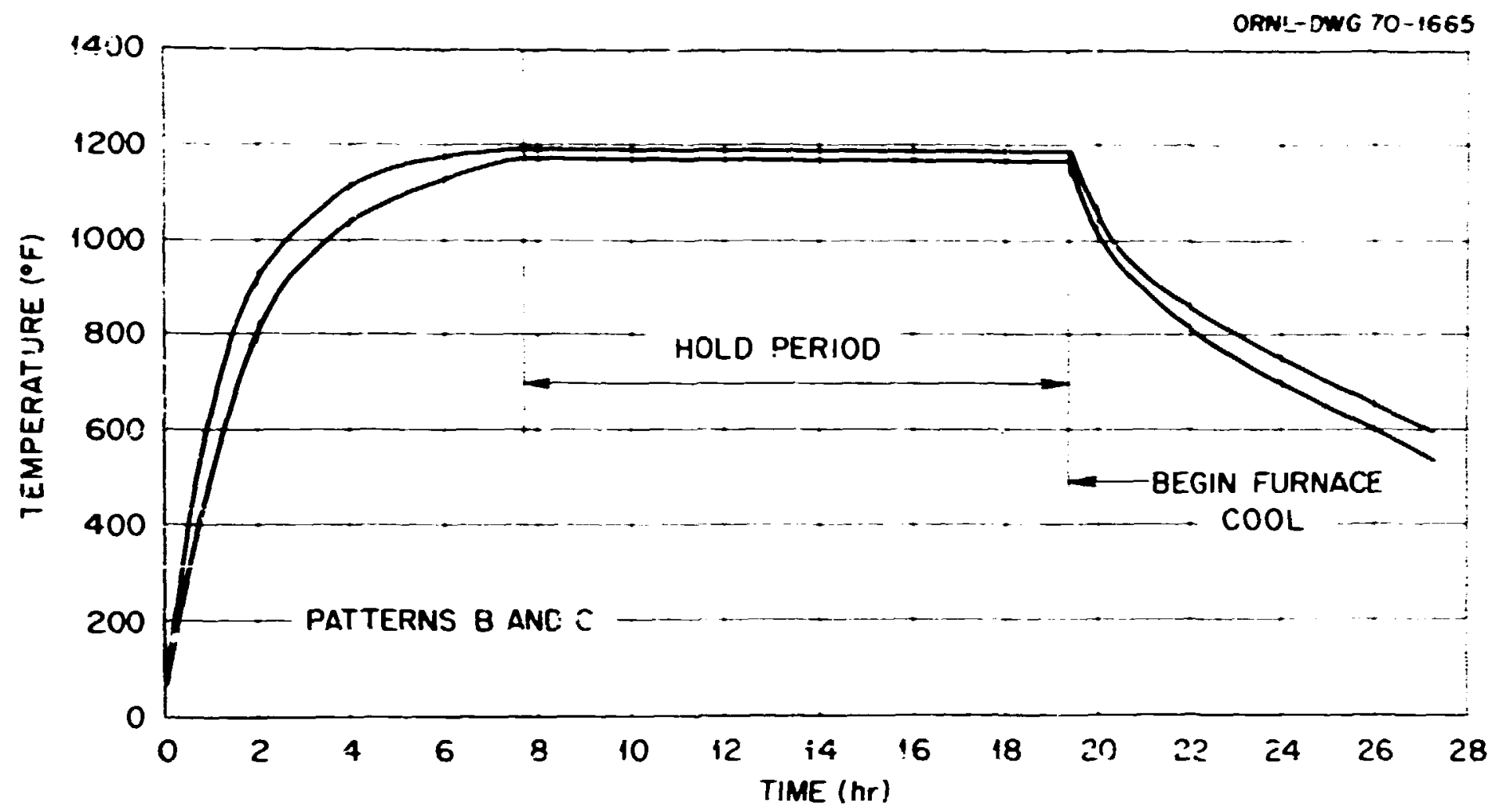

Fiz 1.27. Spread in Thermoccuple Readings During Retimpering of Patterns B and C.

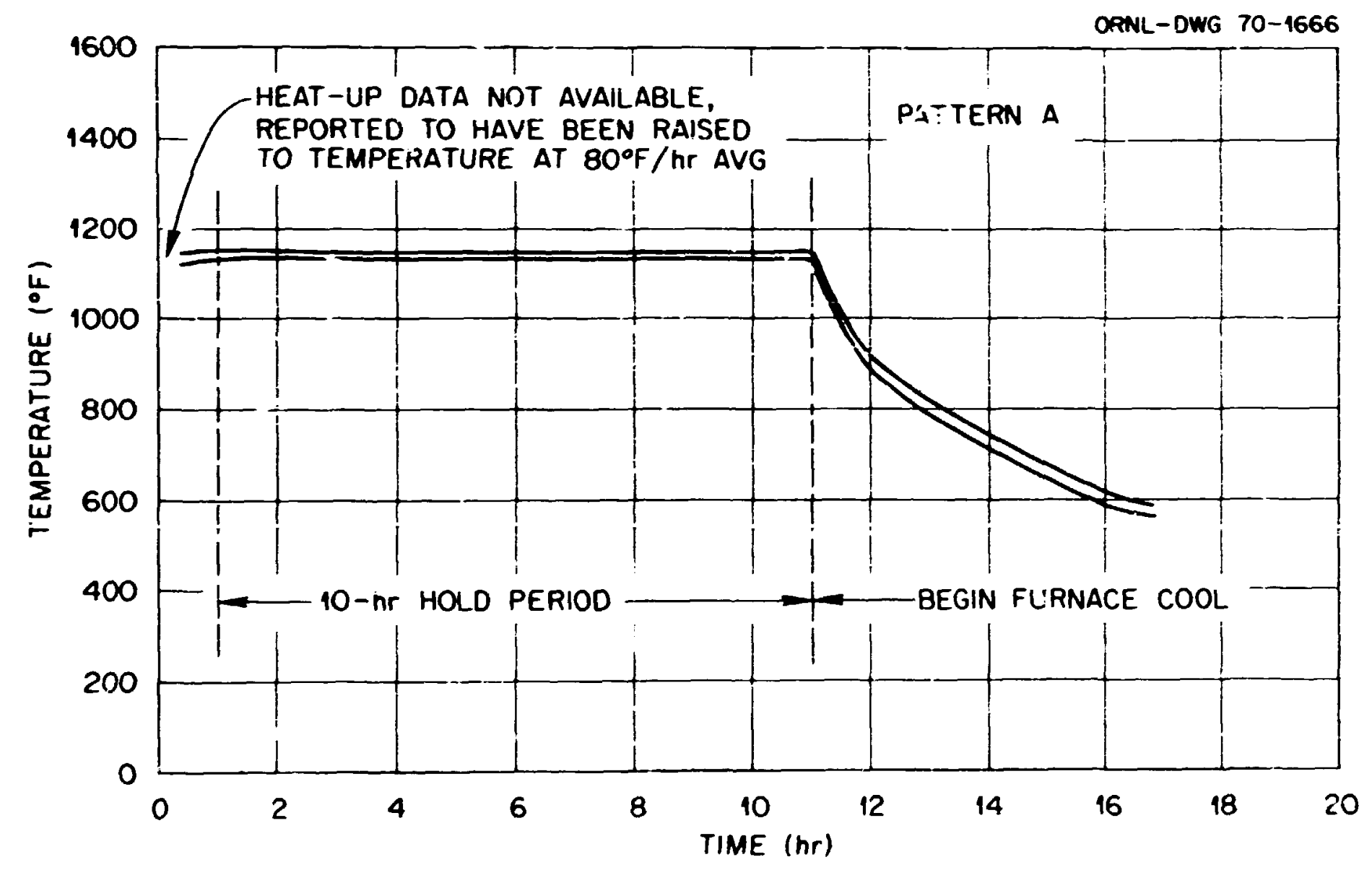

Fig. 1.28. Spread in Thermocouple Readings During Retempering of Pattern A. 


\section{E. CHEMICAl ANALYSIS AND RETESTING FOR MECHANICAL PROFFRTIES}

Check analyses for chemical composition were made from the unused test material from each pattern. The results of those analyses are as follow:

\begin{tabular}{|c|c|c|c|c|c|c|c|c|c|c|c|c|c|}
\hline \multirow[b]{2}{*}{ Pattern } & \multicolumn{2}{|c|}{ Location } & \multirow[b]{2}{*}{$c$} & \multirow[b]{2}{*}{ Mn } & \multirow[b]{2}{*}{$\mathbf{P}$} & \multirow[b]{2}{*}{$\mathbf{S}$} & \multirow[b]{2}{*}{$\mathrm{Cu}$} & \multirow[b]{2}{*}{$\mathbf{N i}$} & \multirow[b]{2}{*}{$C_{r}$} & \multirow[b]{2}{*}{ Mo } & \multirow[b]{2}{*}{ Si } & \multirow[b]{2}{*}{$\mathbf{A}$} & \multirow[b]{2}{*}{$\mathbf{v}$} \\
\hline & Slab & Gaye & & & & & & & & & & & \\
\hline $\mathbf{c}$ & Top & Bottom & 0.1 & 0.3 & .019 & 0.014 & 0.16 & 3.40 & 1.6 & 0.5 ? & 0.25 & 0.019 & \\
\hline 1 & Top & Bottotn $1 / 4 T$ & 0.16 & 0.35 & 0.015 & 0.012 & 0.18 & 3.40 & 1.65 & 0.60 & 0.27 & 0.019 & \\
\hline B & Top & Bottom $1 / 4 T$ & 0.16 & 0.32 & 0.013 & 0.017 & $0.10^{\circ}$ & 3.45 & $1.6 j$ & 0.55 & 0.26 & 0.017 & 1.0 \\
\hline B & Botton & Bottom $1 / 4 T$ & 0.14 & 0.32 & 0.009 & 0.017 & 0.16 & 3.40 & 1.54 & 0.58 & 0.22 & 0.027 & 0.02 \\
\hline
\end{tabular}

The results of mec'lanical iesting after retempering are listed ir. Table 1.1.

\section{F. ULTRASONIC INSPECTION AFT ER HEAT TREATMENT}

Uitrasonic inspection after heat treatment was performed during the week ending June 14, 1769. Each pattern was inspected frum the top surface only, which was prepured by grinding to an approximate 250 rms finish. Patteins $A$ anc $C$ were inspected in Gue portion of the mill. Sufficient crane lifting capacity was not available in this section of the mill; therefore, it was necessary to inspect pattern $B$ in anuther section. Consequently. the inspections were performed by different personnel and with different equipment.

Only that portion of the plate mater al comprising tha ciesignated patterns was inspected. The excess (overall) material on the ends of patterns $B$ and $C$ was rot inspectef.

As previously mentioned, all inspection was pefformed in accordance with the PVRC Subcommittee Report of April 10, 1967. Calibration of the ultr.sonic equipment for inspection before heat treatment was performed using the Midrale-Heppenstall reference block (see Fig. 1.1). A slightly different reference block, made by Combustion Engineering, Inc., and shown in Fig. 1.29, was used for calibrating equipment during this inspection.

Two reflectoscopes, n.odels UM-715 and UM-721, were usea. The UM-715 was used to inspect patterns $A$ and $C$, UM-721 for inspeiting pattern B. The transducers for longitudinai-wave inspection were $1 \frac{11 / 8}{8}$ in. in dianieter and $2 \frac{1}{4} \mathrm{MHz}$ frequency. Shear-wave inspection was performed with $1 \times 1 \mathrm{in}$., $1-\mathrm{MHz}$ crystals. The souplant for each inspectior: vas glycerin and water.

\section{F.i Longitudinal-Wave Inspection}

The DAC curve used for inspection of patterns $A$ and $C$ is shown in Fig. 1.30. Each pattern was scanned essentially as described in part C.I. No "recordable" longitudinal-wave indications were found in pattern C. Pattern A contained six "recordable" longitudinal-wave indications which produced signals in excess of the DAC curve, but none caused any ncticeable loss of bark-surface reflection. The locations of these spct-type indications are shown in Fig. 131.

No recordable longitudinal-wave indications were found in pattern B.

\section{F.2 Sher. Wrs, Inspection}

Tinrze technicians performed the work during shear-wave inspection of the three patterns, a differen: technician for each pattern. The shear-wave DAC curves pletied by each of the technicians ar: shows? :al Fizs. 1.32, 1.33, and 1.34 for patterns A, B, and C respectively. No "recordable" shear-wave indications were found in either pattern. 
Table 1.1. Mechanicil Test Data for 10-in.-thick ASTM A-543 Plate

\begin{tabular}{|c|c|c|c|c|c|c|c|c|c|c|c|c|}
\hline \multirow{2}{*}{ Speciflution } & \multirow{2}{*}{ Dattern } & \multicolumn{2}{|c|}{ Location } & \multirow{2}{*}{ Direction } & \multirow{2}{*}{$\begin{array}{c}\text { Yivld } \\
\text { Strength } \\
\text { (issi) }\end{array}$} & \multirow{2}{*}{$\begin{array}{c}\text { Ultimate } \\
\text { Tensile } \\
\text { 3trength } \\
\text { (ksi) }\end{array}$} & \multirow{2}{*}{$\begin{array}{l}\text { Elongation, } \\
\text { Percent } \\
\text { in } 2 \text { in. }\end{array}$} & \multirow{2}{*}{$\begin{array}{l}\text { NI:T } \\
\left({ }^{\circ} 1:\right)\end{array}$} & \multicolumn{4}{|c|}{ Average $\mathrm{r}(1 \mathrm{ll}, \mathrm{C} \mathrm{VN}$} \\
\hline & & In Ingot & Through Gage & & & & & & $\begin{array}{c}\text { Rivoin } \\
\text { Teinferature } \\
\end{array}$ & $+10^{\circ} \mathrm{Y}$ & $-50^{\circ} \mathrm{F}$ & $120^{\circ} \mathrm{F}$ \\
\hline Cass 2 & $A$ & Top & Bottom $1 / 4 T$ & $\begin{array}{l}L \\
L \\
T \\
T\end{array}$ & $\begin{array}{l}120.2 \\
119.2 \\
118.5 \\
120.8\end{array}$ & $\begin{array}{l}131.6 \\
131.8 \\
131.1 \\
133.5\end{array}$ & $\begin{array}{l}19 \\
21 \\
21 \\
20\end{array}$ & 100 & $\begin{array}{l}87 \\
88\end{array}$ & $\begin{array}{l}83 \\
88\end{array}$ & $\begin{array}{l}64 \\
59\end{array}$ & $\begin{array}{l}33 \\
30\end{array}$ \\
\hline \multirow[t]{3}{*}{ Caxs 1} & $\mathbf{B}$ & Top & Bottom $1 / 4 T$ & $\mathbf{L}$ & $\begin{array}{l}111.3 \\
109.7\end{array}$ & $\begin{array}{l}122.6 \\
122.2\end{array}$ & $\begin{array}{l}23 \\
20\end{array}$ & 80 & 83 & 70 & 49 & 24 \\
\hline & P & Bottom & Bottom $1 / 4 T$ & $\begin{array}{l}T \\
L \\
L\end{array}$ & $\begin{array}{l}103.0 \\
103.0\end{array}$ & $\begin{array}{l}115.9 \\
115.8\end{array}$ & $\begin{array}{l}22 \\
24\end{array}$ & .70 & $\begin{array}{r}74 \\
101\end{array}$ & $\begin{array}{l}6 C \\
87\end{array}$ & $\begin{array}{l}36 \\
52\end{array}$ & 30 \\
\hline & & & & $\begin{array}{l}\mathbf{T} \\
\mathbf{T}\end{array}$ & $\begin{array}{l}103.5 \\
103.5\end{array}$ & $\begin{array}{l}115.9 \\
116.0\end{array}$ & $\begin{array}{l}22 \\
23\end{array}$ & & 19 & 65 & 40 & 29 \\
\hline Mase 1 & 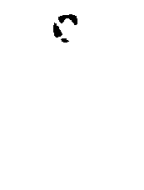 & Top & Bottom $1 / 4 T$ & $\begin{array}{l}L \\
L \\
T \\
r\end{array}$ & $\begin{array}{l}104.0 \\
104.3 \\
104.8 \\
110.4\end{array}$ & $\begin{array}{l}119.0 \\
119.5 \\
118.4 \\
124.0\end{array}$ & $\begin{array}{l}21 \\
20 \\
21 \\
20\end{array}$ & 90 & $\begin{array}{l}80 \\
74\end{array}$ & $\begin{array}{l}69 \\
64\end{array}$ & $\begin{array}{l}45 \\
34\end{array}$ & $\begin{array}{l}24 \\
26\end{array}$ \\
\hline
\end{tabular}


ORNL-DWG 69-\$052

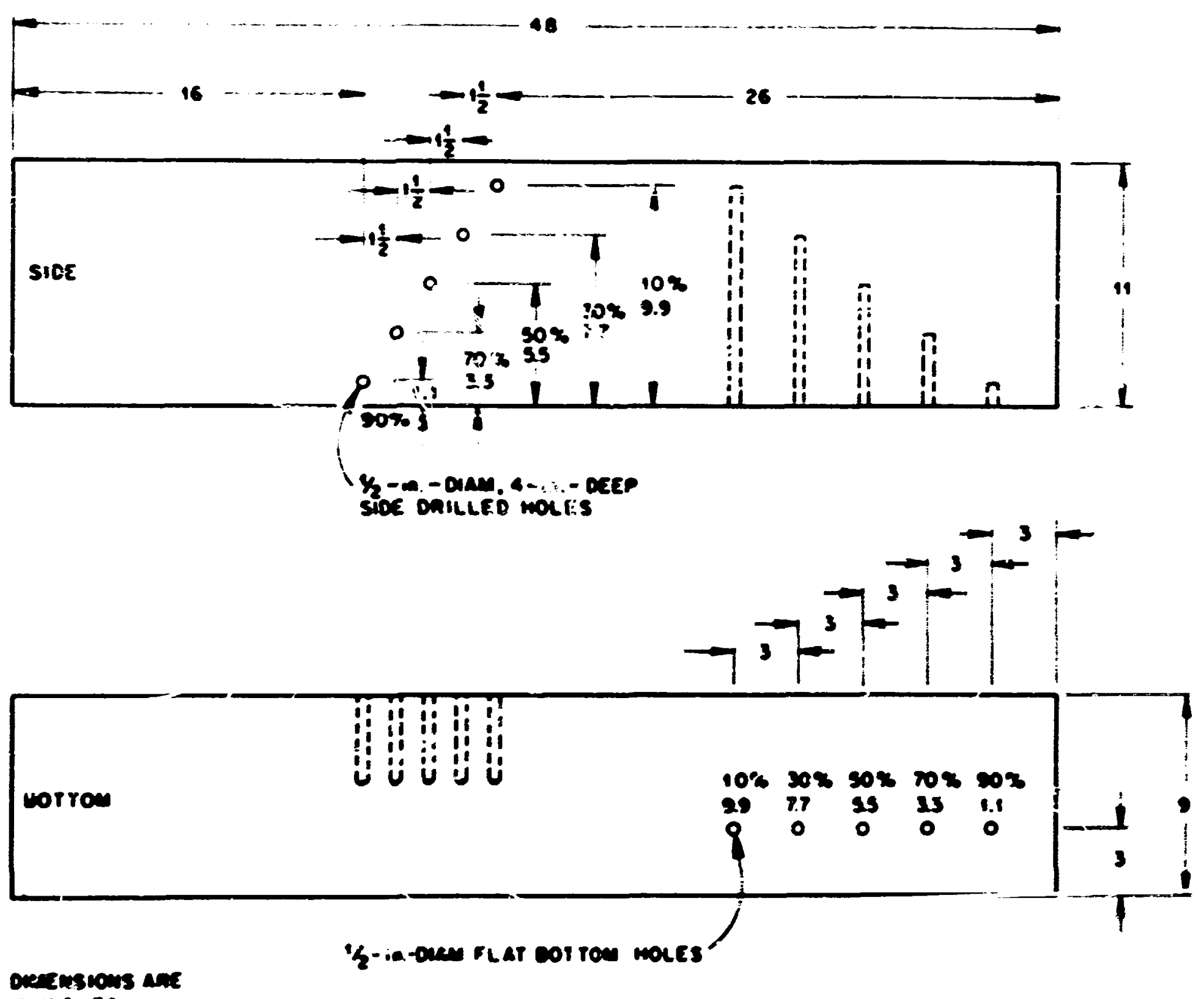

in menes

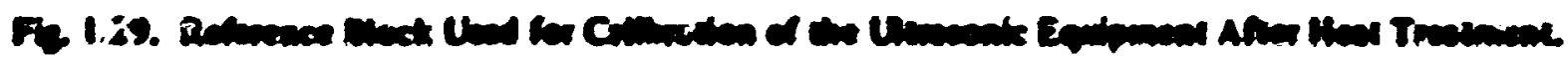




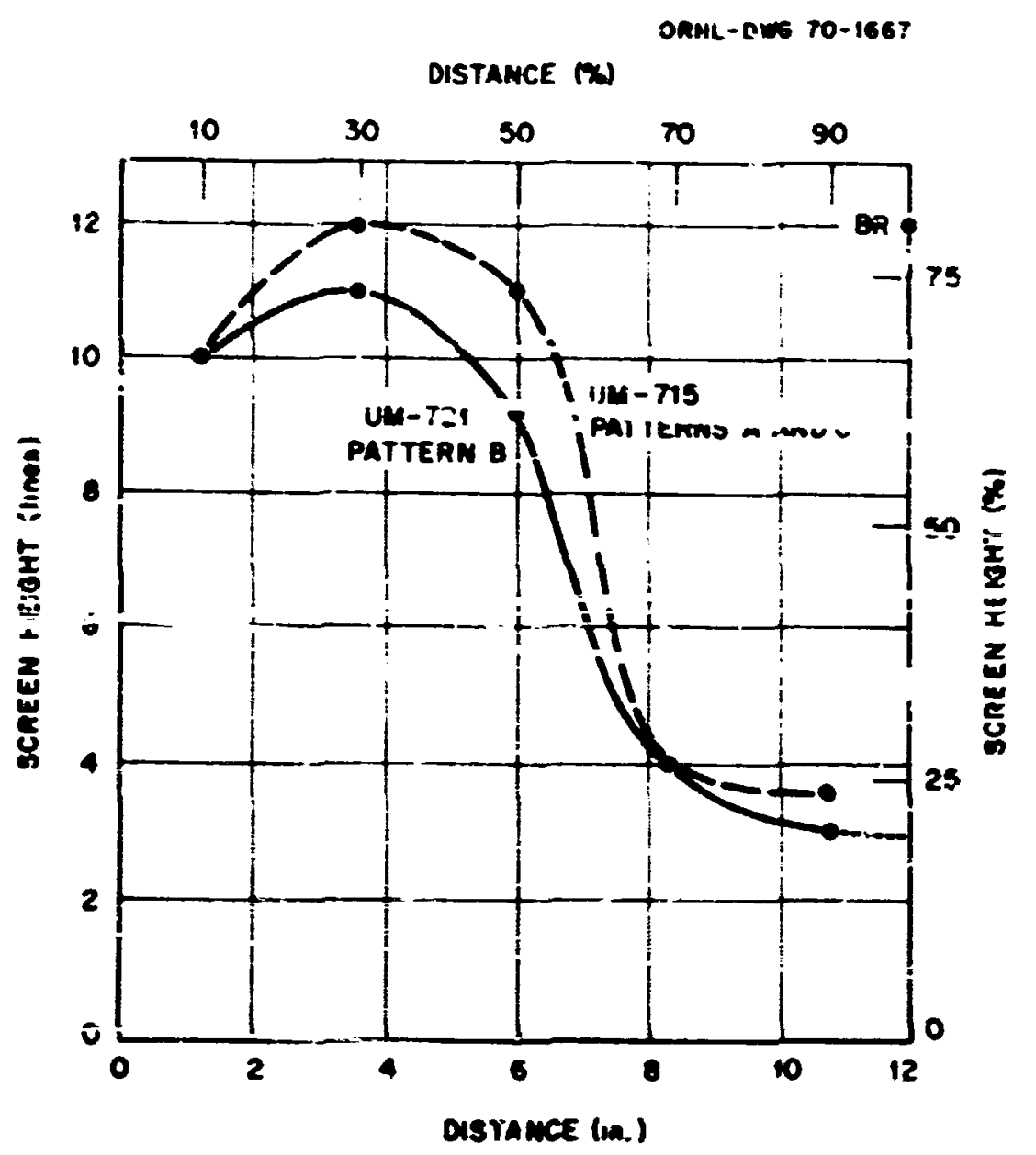

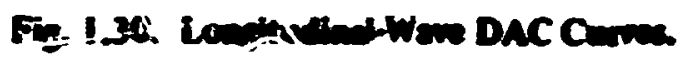

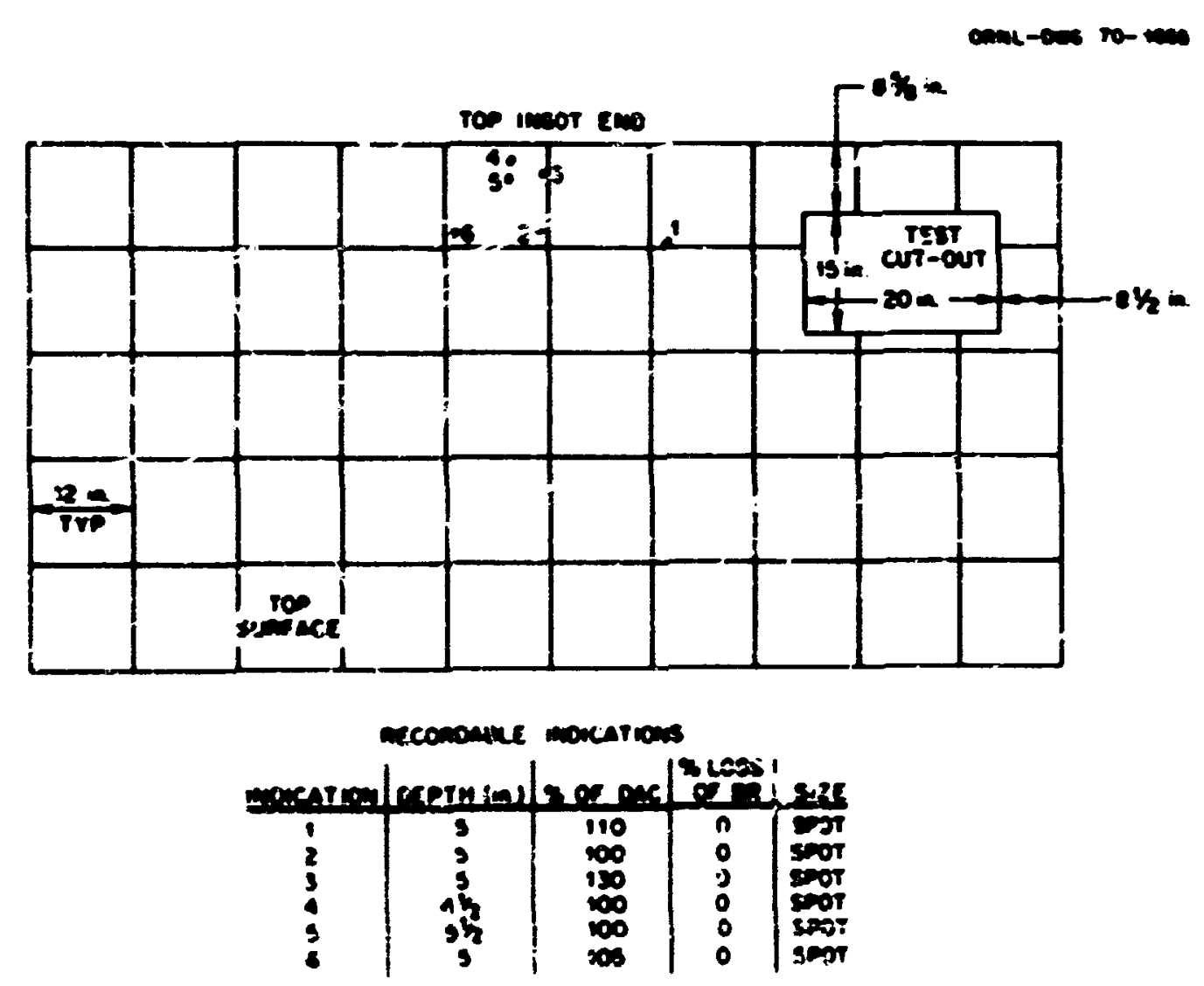

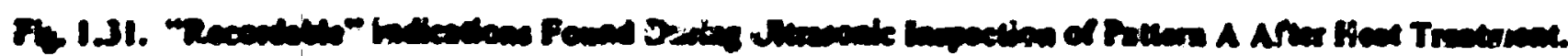




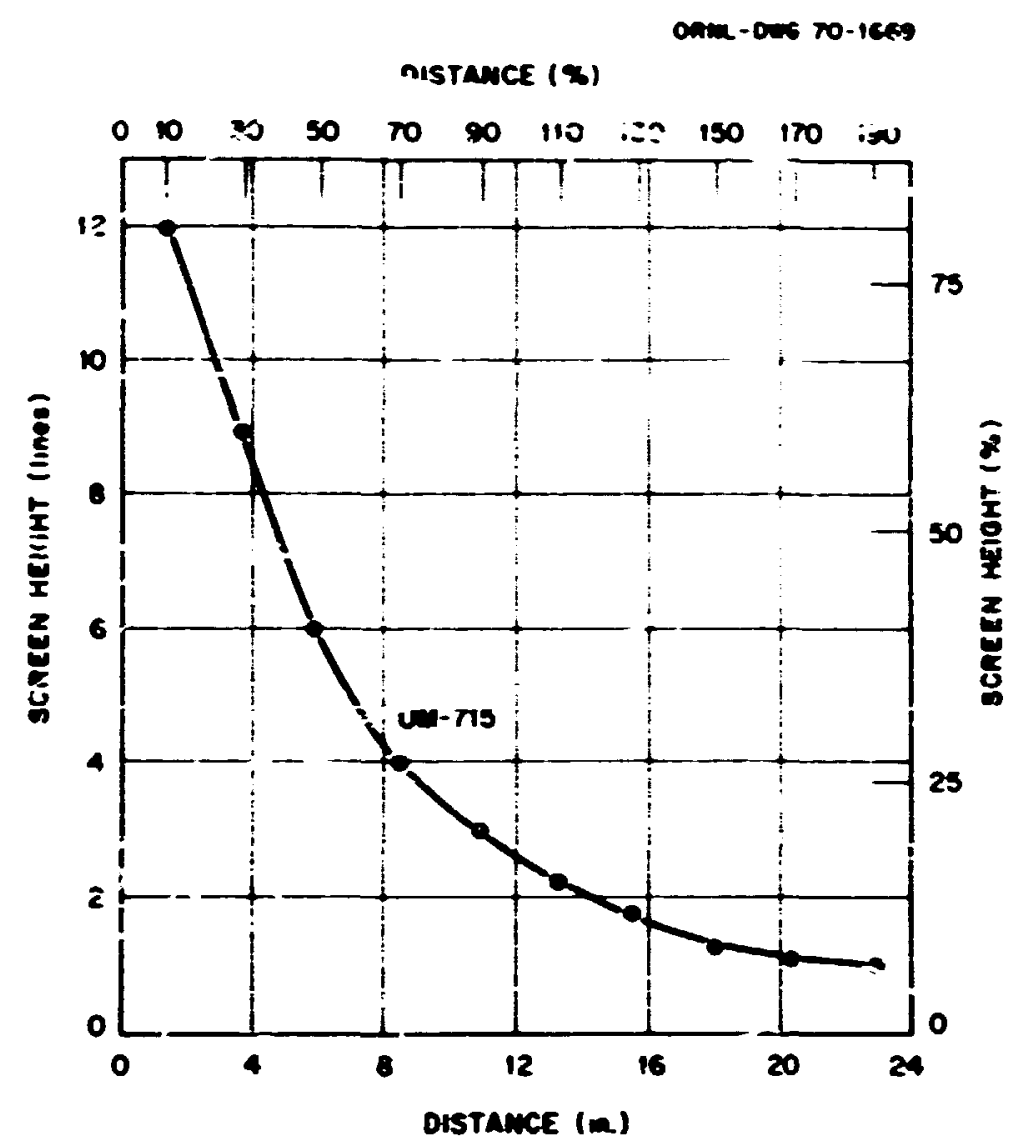

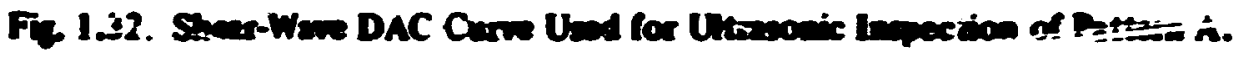

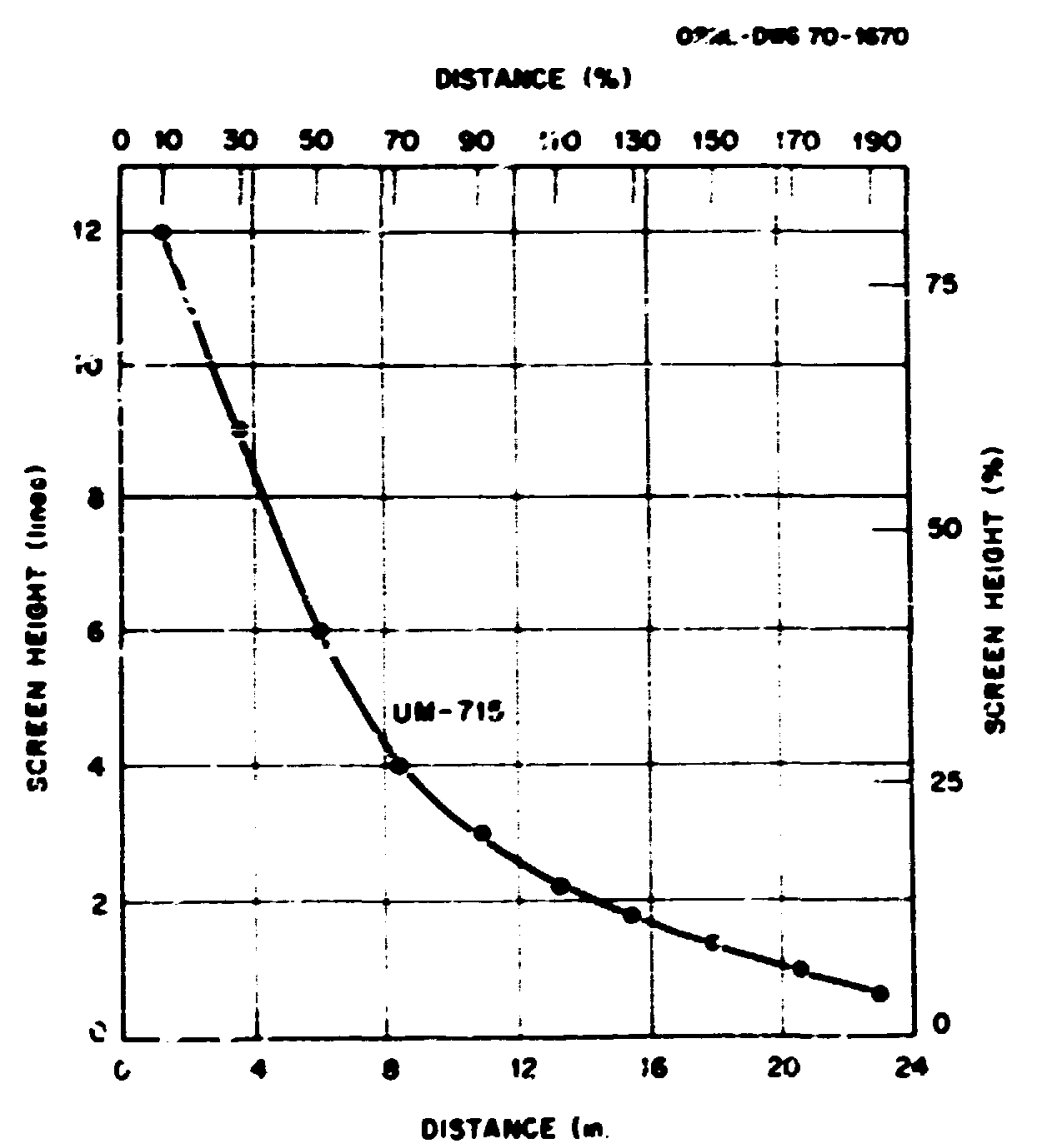

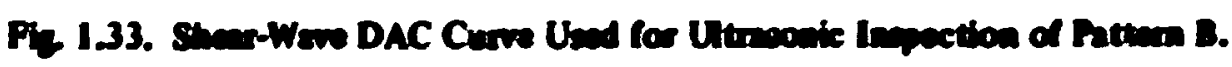




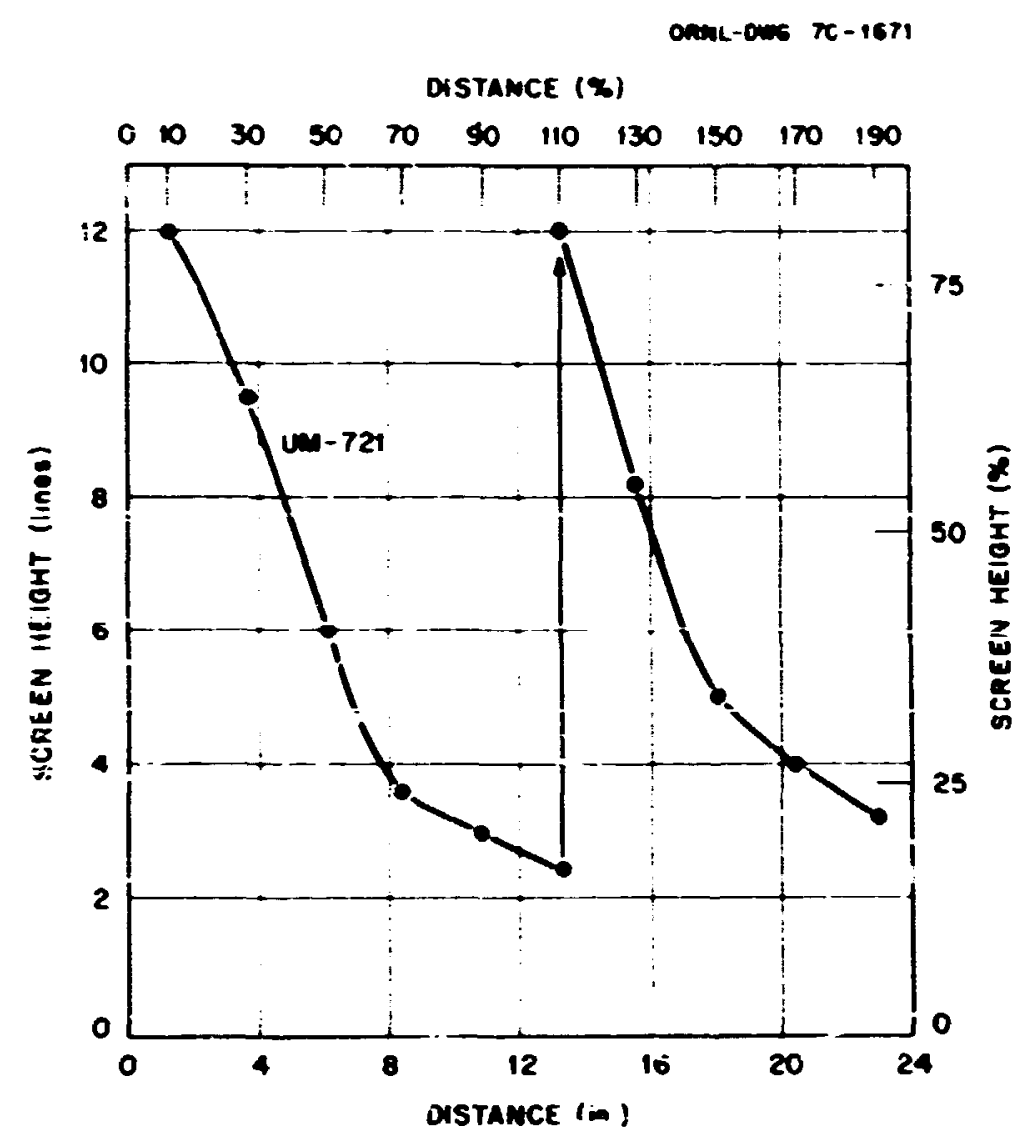

Fa. 1.34. Shear-Wave DAC Carve Uned for Ultzaconic Inpection of Battern C.

\section{G. DMMENSIONAL DATA}

As noted previously in this report, the plate was provided with $1 / 4$-in.-diam holes in both top and bottom surfaces, about 3 in. inside each pattern comer. These were used as reference points for determining the length, width, and diagonal dimensional changes resulting frem she heat treatments. The results of the dimensional inspections are listed in Tables $1.2,1.3$, and 1.4 for patterns $A, B$, and $C$ rexpectively.

On completion of the mill work, the patterns were shipped to the HSST storage facility in Oak Ridge. In keeping with the HSST Program's conventional numbering system, pattern $C$ inss been ascigned phto: number 07 , pattern $A, 08$, and pattern $B, 09$. 
Toble 1.2. Limomilonal Crapepe During Hout 'rreatmant, Pattorn A

In inches

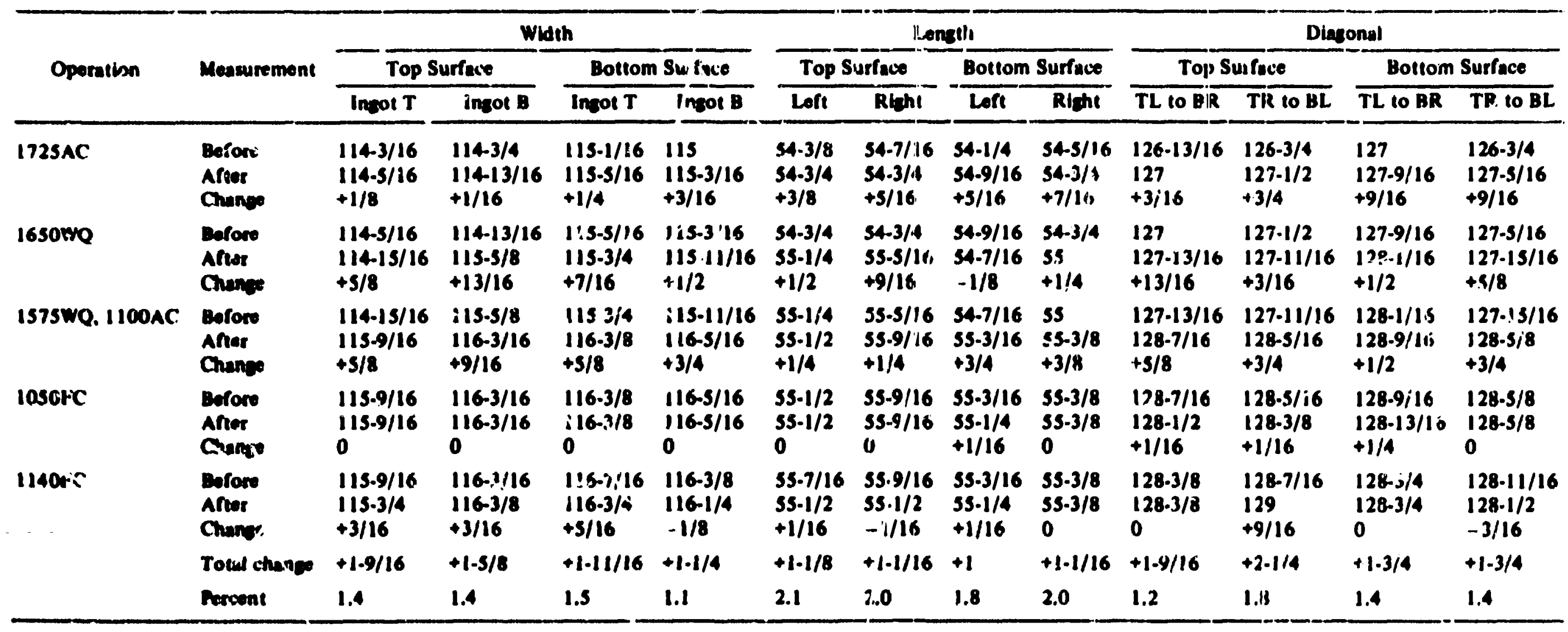




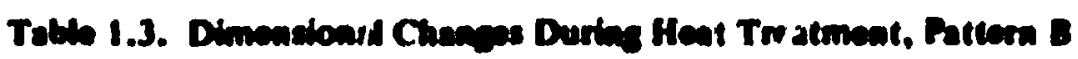

In inches

\begin{tabular}{|c|c|c|c|c|c|c|c|c|c|c|c|c|c|}
\hline \multirow{3}{*}{ Oserntion } & \multirow{3}{*}{ Mosenomont } & \multicolumn{4}{|c|}{ widen } & \multicolumn{4}{|c|}{ Length } & \multicolumn{4}{|c|}{ Diegonal } \\
\hline & & \multicolumn{2}{|c|}{ Top Surfince } & \multicolumn{2}{|c|}{ Bollom Surface } & \multicolumn{2}{|c|}{ Top Surfexe } & \multicolumn{2}{|c|}{ Bollom Surfáa } & \multicolumn{2}{|c|}{ Top Surfaco } & \multicolumn{2}{|c|}{ Boltom Surface } \\
\hline & & Inol $T$ & Inose 1 & Bisent $T$ & Ireot B & Left & Right & Left & Right & TL 10. BR & TR $10 \mathrm{BL}$ & TL to $B R$ & TR $10 \mathrm{BL}$ \\
\hline 172SAC & $\begin{array}{l}\text { Defor } \\
\text { Afon } \\
\text { Shanes }\end{array}$ & $\begin{array}{l}114.5 / 16 \\
114-7116 \\
+118\end{array}$ & $\begin{array}{l}114.1 / 4 \\
115-3 / n \\
+1 / 8\end{array}$ & $\begin{array}{l}114-3 / 4 \\
115-1 / 16 \\
+5 / 16\end{array}$ & $\begin{array}{l}1 / 4-5 / 8 \\
114-13 / 16 \\
+! i / 16\end{array}$ & $\begin{array}{l}138-7 / 16 \\
138-3 / 4 \\
+5 / 16\end{array}$ & $\begin{array}{l}138-1 / 2 \\
138-7 / 8 \\
+3 / 8\end{array}$ & $\begin{array}{l}138-1 / 16 \\
138-3 / 16 \\
+1 / 8\end{array}$ & $\begin{array}{l}138-3 / 8 \\
138-3 / 4 \\
+3 / 8\end{array}$ & $\begin{array}{l}179.5 / 11 \\
180 \\
+3 / 8\end{array}$ & $\begin{array}{l}180 \\
180-3 / 16 \\
+3 / 16\end{array}$ & $\begin{array}{l}180-1 / 16 \\
180-1 / 2 \\
.3 / 16\end{array}$ & $\begin{array}{l}179.1 / 2 \\
179.3 / 4 \\
+1 / 4\end{array}$ \\
\hline 1650160 & 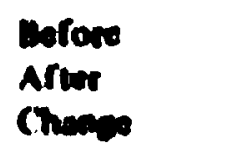 & $\begin{array}{l}114-7 / 16 \\
13.1 / 4 \\
+13 / 16\end{array}$ & $\begin{array}{l}115.3 / 8 \\
116.1 / 4 \\
+7 / 8\end{array}$ & $\begin{array}{l}115-1 / 16 \\
115-1 / 2 \\
+7 / 16\end{array}$ & $\begin{array}{l}114-15 / 16 \\
115-5 / 8 \\
+11 / 16\end{array}$ & $\begin{array}{l}138-3 / 4 \\
139.11 / 16 \\
+15 / 16\end{array}$ & $\begin{array}{l}138-5 / 8 \\
139-3 / 4 \\
+1.1 / 8\end{array}$ & $\begin{array}{l}138.3 / 16 \\
139.3 / 4 \\
+1.9 / 16\end{array}$ & $\begin{array}{l}138-3 / 4 \\
139-11 / 16 \\
+15 / 16\end{array}$ & $\begin{array}{l}180 \\
181.1 / 14 \\
+1.1 / 4\end{array}$ & $\begin{array}{l}180-3 / 16 \\
181-5 / 16 \\
+1.1 / 8\end{array}$ & $\begin{array}{l}180-1 / 2 \\
181.5 / 8 \\
+1.1 / 2\end{array}$ & $\begin{array}{l}179.3 / 4 \\
180.7 / 8 \\
+1.1 / 8\end{array}$ \\
\hline ISTSWOO. IIOUAC & $\begin{array}{l}\text { Dufore } \\
\text { Allor } \\
\text { Chunese }\end{array}$ & $\begin{array}{l}115-1 / 4 \\
115-3 / 4 \\
+1 / ?\end{array}$ & $\begin{array}{l}116-1 / 4 \\
116-11 / 16 \\
+7 / 16\end{array}$ & $\begin{array}{l}11,6-1 / 2 \\
116-1 / 8 \\
+5 / 8\end{array}$ & $\begin{array}{l}115.5 / 8 \\
118-1 / 18 \\
+7 / 16\end{array}$ & $\begin{array}{l}139.11 / 16 \\
140.7 / 16 \\
4.3 / 4\end{array}$ & $\begin{array}{l}139.3 / 4 \\
140.5 / 8 \\
+7 / 8\end{array}$ & $\begin{array}{l}139.3 / 4 \\
140-9 / 16 \\
+13 / 16\end{array}$ & $\begin{array}{l}139.11 / 16 \\
140.1 / 2 \\
+13 / 16\end{array}$ & $\begin{array}{l}181 \cdot 1 / 14 \\
182 \cdot 1 / 16 \\
+1\end{array}$ & $\begin{array}{l}181.5 / 16 \\
182-5 / 16 \\
+1\end{array}$ & $\begin{array}{l}181.5 / 8 \\
182.9 / 16 \\
+15 / 16\end{array}$ & $\begin{array}{l}180.7 / 8 \\
181-3 / 4 \\
+15 / 16\end{array}$ \\
\hline 1140 & $\begin{array}{l}\text { Defere } \\
\text { Alfas } \\
\text { Chames }\end{array}$ & $\begin{array}{l}115.3 / 4 \\
115.7 / 10 \\
+1 / 8\end{array}$ & $\begin{array}{l}116-11 / 16 \\
116-3 / 4 \\
+1 / 16\end{array}$ & $\begin{array}{l}116-1 / 8 \\
116-1 / 4 \\
+1 / 8\end{array}$ & $\begin{array}{l}116-1 / 16 \\
1: 6-1 / 8 \\
+1 / 16\end{array}$ & $\begin{array}{l}1407 / 16 \\
140-1 / 2 \\
+1 / 16\end{array}$ & $\begin{array}{l}140-5 / 8 \\
140-7 / 16 \\
-3 / 16\end{array}$ & $\begin{array}{l}140-9 / 16 \\
140-9 / 16 \\
0\end{array}$ & $\begin{array}{l}140-1 / 2 \\
140-5 / 8 \\
+1 / 8\end{array}$ & $\begin{array}{l}182-1 / 14 \\
182-1 / 4 \\
0\end{array}$ & $\begin{array}{l}182-5 / 16 \\
182-1 / 4 \\
-1 / 16\end{array}$ & $\begin{array}{l}182.9 / 16 \\
182.5 / 8 \\
+1 / 16\end{array}$ & $\begin{array}{l}181-3 / 4 \\
181-13 / 16 \\
+1 / 16\end{array}$ \\
\hline Icisni-c & $\begin{array}{l}\text { motors } \\
\text { Anter } \\
\text { Chimes }\end{array}$ & $\begin{array}{l}123.9 / 8 \\
115-3 / 4 \\
-1 / 4\end{array}$ & $\begin{array}{l}116-3 / 4 \\
116-1 / 16 \\
-11 / 16\end{array}$ & $\begin{array}{l}116-1 / 4 \\
116-3 / 16 \\
-1 / 16\end{array}$ & $\begin{array}{l}116-1 / 8 \\
116-1 / 16 \\
-1 / 16\end{array}$ & $\begin{array}{l}140-1 / 2 \\
140-7 / 16 \\
-1 / 16\end{array}$ & $\begin{array}{l}140.7 / 16 \\
140-5 / 6 \\
+3 / 16\end{array}$ & $\begin{array}{l}140-9 / 16 \\
140-1 / 2 \\
-1 / 16\end{array}$ & $\begin{array}{l}140-5 / 8 \\
140-5 / 8 \\
0\end{array}$ & $\begin{array}{l}187.1 / 4 \\
182.1 / 4 \\
0\end{array}$ & $\begin{array}{l}182 \cdot 1 / 4 \\
182.5 / 16 \\
+1 / 16\end{array}$ & $\begin{array}{l}182.5 / 8 \\
182-11 / 16 \\
+1 / 8\end{array}$ & $\begin{array}{l}181.13 / 16 \\
181.3 / 4 \\
-1 / 16\end{array}$ \\
\hline \multirow[t]{3}{*}{ Innotc } & $\begin{array}{l}\text { Defore } \\
\text { Afret } \\
\text { Clangere }\end{array}$ & $\begin{array}{l}115.13 / 16 \\
115.3 / 8 \\
7 / 16\end{array}$ & $\begin{array}{l}116-1 / 16 \\
116-5 / 8 \\
+9 / 16\end{array}$ & $\begin{array}{l}116.1 / 16 \\
1: 6.1 / 4 \\
+1 / 16\end{array}$ & $\begin{array}{l}116 \\
116 \\
0\end{array}$ & $\begin{array}{l}140.1 / 2 \\
140.7 / 16 \\
-1 / 86\end{array}$ & $\begin{array}{l}140-5 / 8 \\
140-9 / 16 \\
-1 / 16\end{array}$ & $\begin{array}{l}140-7 / 16 \\
140-3 / 8 \\
-1 / 16\end{array}$ & $\begin{array}{l}140 \\
140.1 / 2 \\
+11^{\circ}\end{array}$ & $\begin{array}{l}182.1 / 4 \\
182.1 / 8 \\
-1 / 13\end{array}$ & $\begin{array}{l}182-3 / 16 \\
182-1 / 4 \\
+1 / 16\end{array}$ & $\begin{array}{l}182-7 / 16 \\
182.9 / 16 \\
+1 / 8\end{array}$ & $\begin{array}{l}181.11 / 16 \\
181.1 i / 16 \\
0\end{array}$ \\
\hline & Tord ellowe & $+1.1 / 16$ & $+2.3 / 8$ & $+1-1 / 2$ & $+1.3 / 4$ & +2 & $+2 \cdot 1 / 16$ & $+2.5 / 16$ & $+2 \cdot 1 / 8$ & $+2-1 / 2$ & $+2-1 / 4$ & $+2.1 / 2$ & $+2.3 / 16$ \\
\hline & Huxcont & 0.9 & 2.1 & 1.3 & $1 ?$ & 1.5 & 1.5 & 1.7 & 1.5 & 1.4 & 1.3 & 1.4 & 1.2 \\
\hline
\end{tabular}




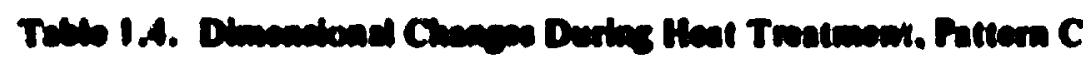

In inches

\begin{tabular}{|c|c|c|c|c|c|c|c|c|c|c|c|c|c|}
\hline \multirow{3}{*}{ Operation } & \multirow{3}{*}{ 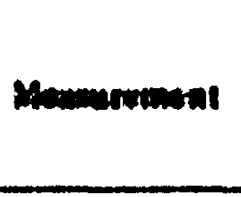 } & \multicolumn{4}{|c|}{ Wrien } & \multicolumn{4}{|c|}{ Longh } & \multicolumn{4}{|c|}{ Diemponal } \\
\hline & & \multicolumn{2}{|c|}{ Top Surfaxe } & \multicolumn{2}{|c|}{ Dotican Surface } & \multicolumn{2}{|c|}{ Top surfece } & \multicolumn{2}{|c|}{ Dollom Surfece } & \multicolumn{2}{|c|}{ Top Surfoce } & \multicolumn{2}{|c|}{ Bollom Surince } \\
\hline & & $\operatorname{lng} 1$ & $\log x$ & $\ln 00 t T$ & $\ln 48$ & Lof & Rlent & Inf & Rint & TL $10 \mathrm{BR}$ & TR $10 \mathrm{BL}$ & TL 10 BR & TR $10 \mathrm{BL}$ \\
\hline $1725 A C$ & $\begin{array}{l}\text { Driose } \\
\text { Alles } \\
\text { anmen }\end{array}$ & $\begin{array}{l}114-1 / 2 \\
114-5 / 2 \\
+1 / 2\end{array}$ & $\begin{array}{l}114-3 / 8 \\
114-1 / 2 \\
+1 / 8\end{array}$ & $\begin{array}{l}115 \\
114-15 / 16 \\
-1 / 16\end{array}$ & $\begin{array}{l}115-1 / 16 \\
115-5 / 16 \\
+1 / 4\end{array}$ & $\begin{array}{l}30-9 / 16 \\
30-13 / 16 \\
+1 / 4\end{array}$ & $\begin{array}{l}30-1 / 2 \\
30-3 / 4 \\
+1 / 4\end{array}$ & $\begin{array}{l}30.5 / 8 \\
30.3 / 4 \\
+1 / 8\end{array}$ & $\begin{array}{l}30-7 / 16 \\
30-7 / 6 \\
+7 / 16\end{array}$ & $\begin{array}{l}118-5 / 16 \\
118-1 / 2 \\
+3 / 16\end{array}$ & $\begin{array}{l}118-1 / 2 \\
118-11 / 16 \\
+3 / 16\end{array}$ & $\begin{array}{l}118-7 / 8 \\
119 \\
+1 / 8\end{array}$ & $\begin{array}{l}119.3 / 8 \\
119.3 / 4 \\
+3 / 8\end{array}$ \\
\hline icsome. IIsanc & 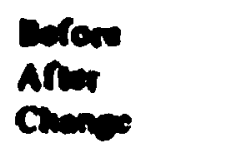 & $\begin{array}{l}1145 / 8 \\
115-5 / 16 \\
+11 / 16\end{array}$ & $\begin{array}{l}114-1 / 2 \\
115-1 / 1 \\
+519\end{array}$ & $\begin{array}{l}114.15 / 16 \\
115-1 / 2 \\
+9 / 16\end{array}$ & $\begin{array}{l}115-5 / 16 \\
115-11 / 16 \\
+3 / 8\end{array}$ & $\begin{array}{l}30 / 3 / 16 \\
31 \\
+3 / 16\end{array}$ & $\begin{array}{l}30-3 / 4 \\
31 \\
+1 / 4\end{array}$ & $\begin{array}{l}30.3 / 4 \\
30.5 / 8 \\
-1 / 8\end{array}$ & $\begin{array}{l}30-7 / 8 \\
31 \\
+1 / 8\end{array}$ & $\begin{array}{l}138-1 / 2 \\
119 \cdot 1 / 8 \\
+5 / 8\end{array}$ & $\begin{array}{l}118-11 / 16 \\
119.3 / 8 \\
+11 / 16\end{array}$ & $\begin{array}{l}119 \\
119.1 / 4 \\
+1 / 4\end{array}$ & $\begin{array}{l}119.3 / 4 \\
119-1 / 2 \\
-1 / 4\end{array}$ \\
\hline losote & 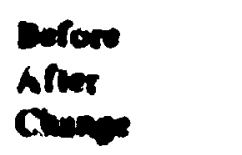 & $\begin{array}{l}115-5 / 16 \\
185-3 / 6 \\
+1 / 16\end{array}$ & $\begin{array}{l}115-1 / 8 \\
115-3 / 16 \\
+1 / 16\end{array}$ & $\begin{array}{l}115-1 / 2 \\
115-9 / 16 \\
11 / 15\end{array}$ & $\begin{array}{l}115-11 / 16 \\
115-3 / 4 \\
+1 / 16\end{array}$ & $\begin{array}{l}31 \\
31-1 / 16 \\
+1 / 16\end{array}$ & $\begin{array}{l}31 \\
31 \\
0\end{array}$ & $\begin{array}{l}30-5 / 8 \\
30-7 / 8 \\
+1 / 4\end{array}$ & $\begin{array}{l}31 \\
31.1 / 16 \\
+1 / 16\end{array}$ & $\begin{array}{l}119.1 / 8 \\
119.3 / 16 \\
+1 / 16\end{array}$ & $\begin{array}{l}119.3 / 8 \\
119.3 / 8 \\
0\end{array}$ & $\begin{array}{l}119.1 / 4 \\
119.5 / 8 \\
+3 / 8\end{array}$ & $\begin{array}{l}119.1 / 2 \\
119.11 / 16 \\
+3 / 16\end{array}$ \\
\hline \multirow[t]{3}{*}{ lleotr: } & 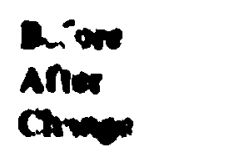 & $\begin{array}{l}115-3 / 8 \\
115-1 / 4 \\
.1 / 8\end{array}$ & $\begin{array}{l}115-1 / 8 \\
115 \\
-1 / 8\end{array}$ & $\begin{array}{l}115-3 / 8 \\
115 \cdot 1 / 2 \\
+1 / 8\end{array}$ & $\begin{array}{l}115-3 / 4 \\
115.3 / 4 \\
0\end{array}$ & $\begin{array}{l}31-3 / 16 \\
31 \\
-3 / 16\end{array}$ & $\begin{array}{l}31 \\
30-1 / 8 \\
-1,8\end{array}$ & $\begin{array}{l}31 \\
30-3 / 4 \\
-1 / 4\end{array}$ & $\begin{array}{l}31-1 / 16 \\
31 \\
-1 / 16\end{array}$ & $\begin{array}{l}119.3 / 1 \\
119.1 / 1 \\
-1 / 4\end{array}$ & $\begin{array}{l}1: 9.3 / 16 \\
119.3 / 8 \\
+3 / 16\end{array}$ & $\begin{array}{l}119.5 / 8 \\
119.3 / 4 \\
+1 / 8\end{array}$ & $\begin{array}{l}119.11 / 16 \\
119.3 / 4 \\
+1 / 16\end{array}$ \\
\hline & Toenl chunese & $13 / 4$ & $+5 / 8$ & $+1 / 2$ & $+11 / 116$ & $+7 / 18$ & $+3 / 8$ & $+1 / 8$ & $+9 / 16$ & $+13 / 16$ & $+7 / 8$ & $+7 / 8$ & $+3 / 8$ \\
\hline & nexingl & 0.66 & 0.ss & 0.44 & $0.6 n$ & 1.4 & 1.2 & 0.41 & 1.8 & 0.69 & 0.74 & 0.74 & 0.31 \\
\hline
\end{tabular}




\section{WELDMENTS}

\section{H. FABRICATION OF WELDMENTS FROM PLATE SECTIONS OF BST RLATE OI}

The bulk of the investigative effor by the HSST Program thus far has been devoled to wrought products. It was therefore decided that some study should be applied to welds. In particular, the two types most often employed in the fabrication of light-water nuclear reactors - submerged-arc and shielded-metalarc welds - were to be given primary consideration.

The decision was made in the earty part of 1968 to pisceed with the fabrication of weldments uning 12-in. thick edoe material from HSST plate 01 . The metting, rolling, and heat treatment of this plate are detaiod in OPNLA313. Very brielly, phate 01 wa:

i. meliedi and rolled by Lukers.

2. shipped to Combustion Engineerine. Inc., for inspectivn and heat treatuneat,

3. Eitresonically isepested before heat treatment, normalized, sinde sustenitized, queached (vertically). tempered to chas I mechavical properties, stres relieved. and ultanonically iapected after beat ireatunent by Combustion.

4. aut so shows in Fir. 2.1 and shipped to the HSST stores facitity in OAk Rides.

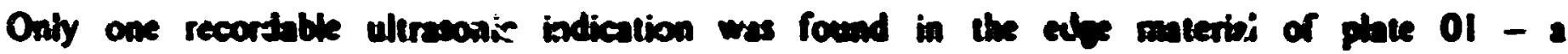

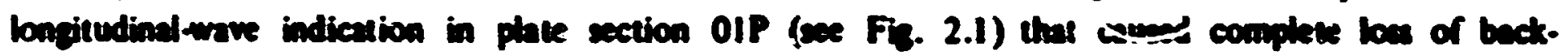
surface reflection. The indication was sinusted boun $30 \mathrm{in}$. from the left thad edpe of the plate (oriented as shown in Fig. 2.1) and termiminted sbout 6 to 8 in. from the boltow edve.

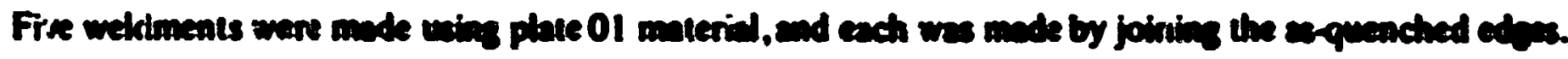

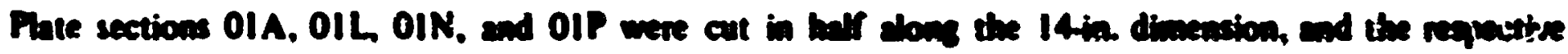

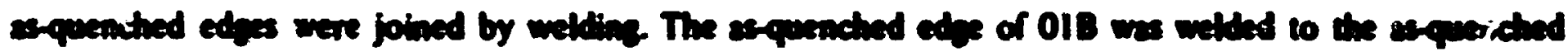

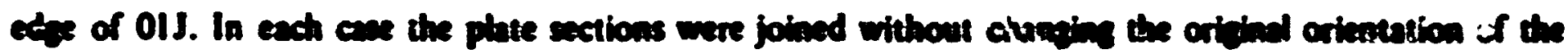
respective top and botion surfacen.

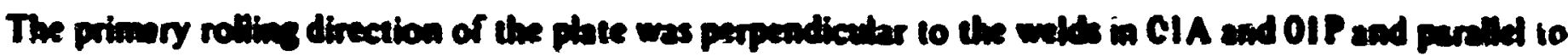

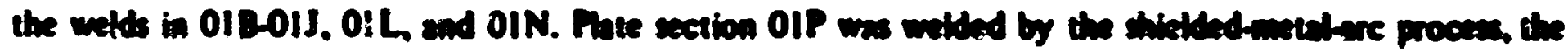

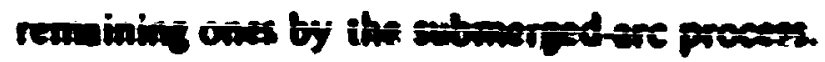

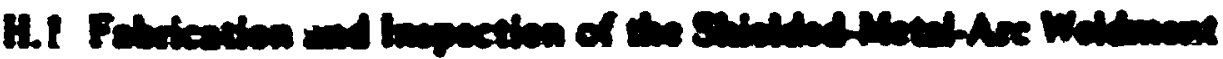

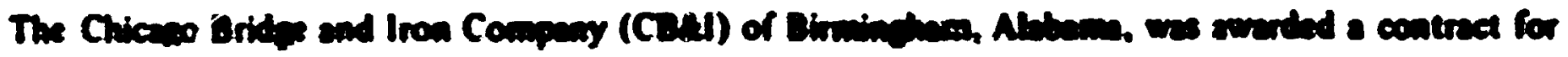

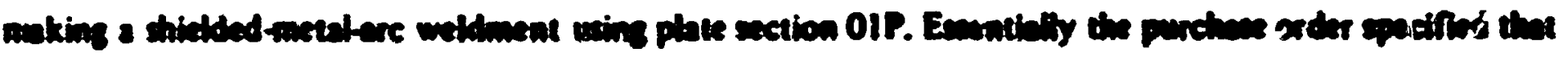

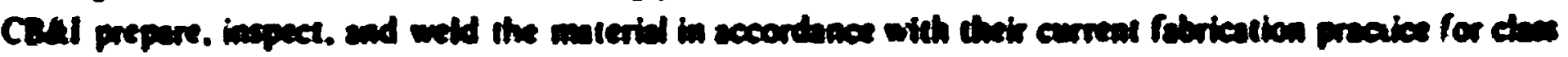

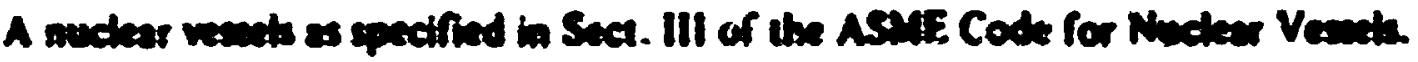

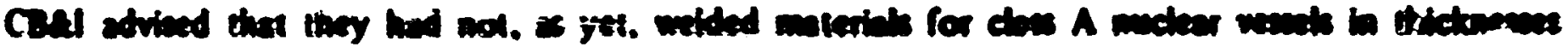

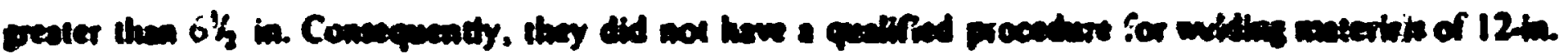

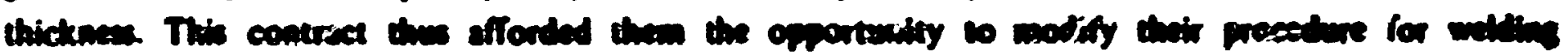

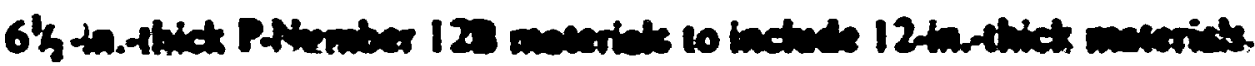

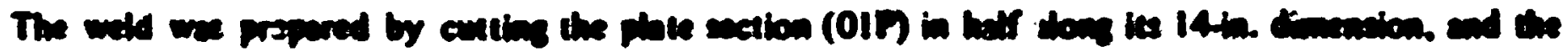

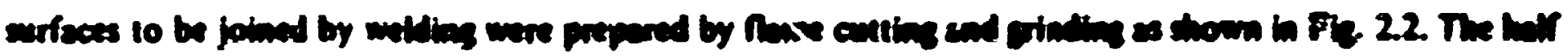

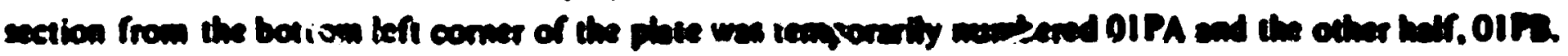




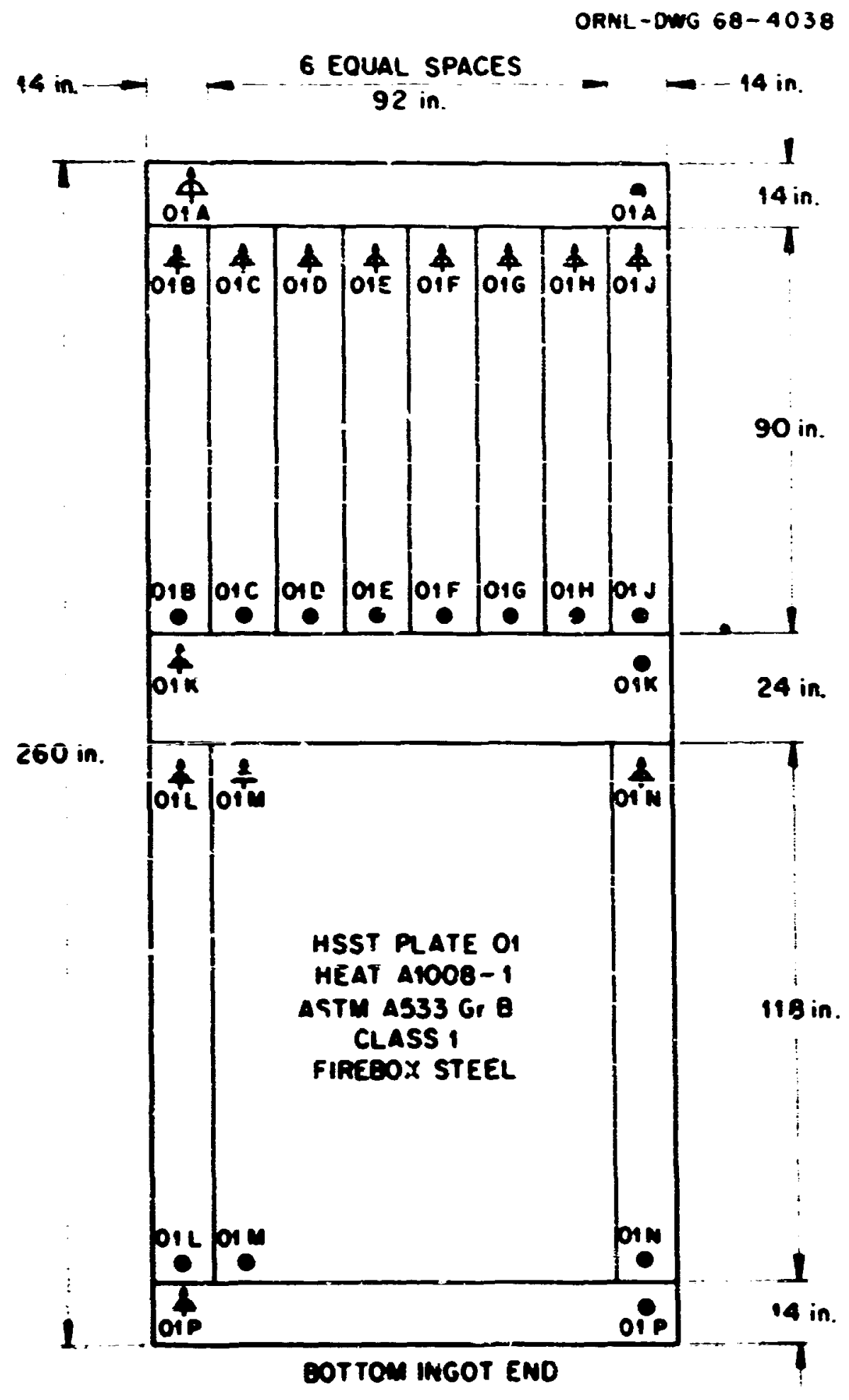

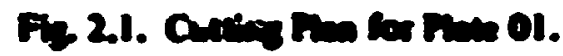

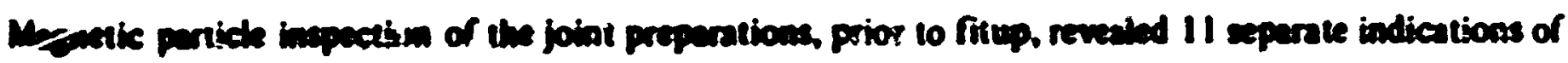

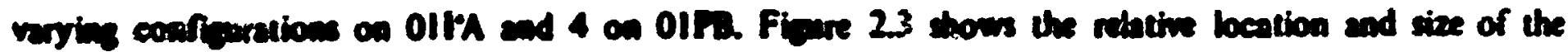

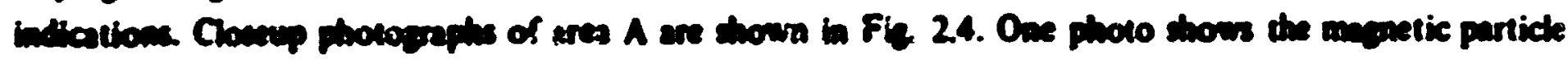

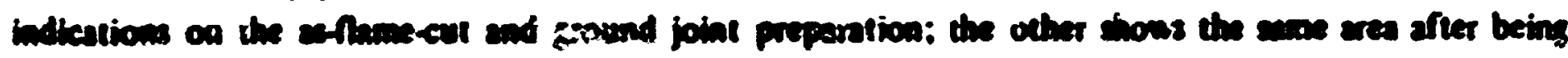

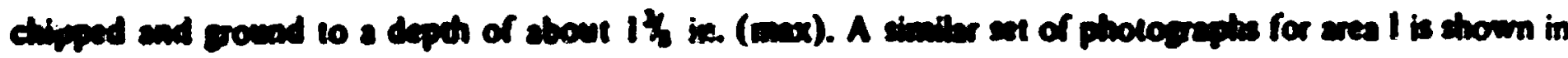

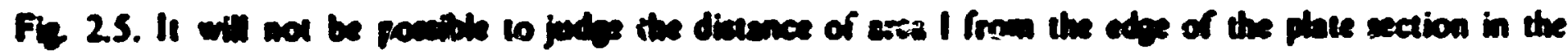

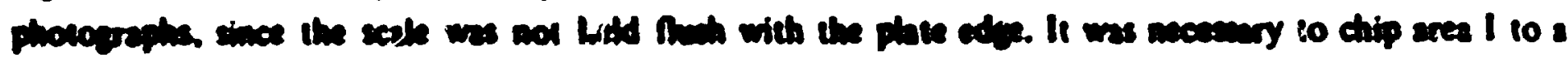

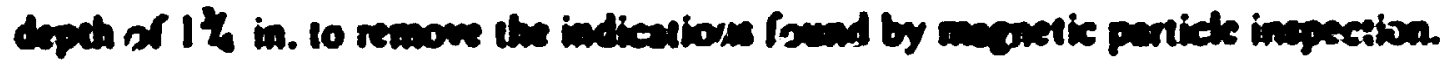


ROOT

ELECTRODE SIZE AND TYPE CURRENT AND POLARITY ARC VOLTAGE
$1 / 8-1 \mathrm{n} . \bar{E}-80,10 \mathrm{im}$ 90-i35 CC-RP $23-25$
ORNL-DWG 69-3432R

h.M.MAINDER

$5 / 32$ ANU $5 / 15-$ in. E-8018 NM $110-220 \mathrm{omp}$

24-26

PREHEAT : $300^{\circ} \mathrm{F}$, HOLD UNTIL PUHT

INTERPASS : $\sim 300^{\circ} \mathrm{F}$

PWHT : HEAT AT $100^{\circ} \mathrm{F} / \mathrm{hr}$ TO $1125^{\circ} \mathrm{F}$ FOR $1 \mathrm{hr} / \mathrm{in}$.

AND COOL AT $100^{\circ} \mathrm{F} / \mathrm{hr}$

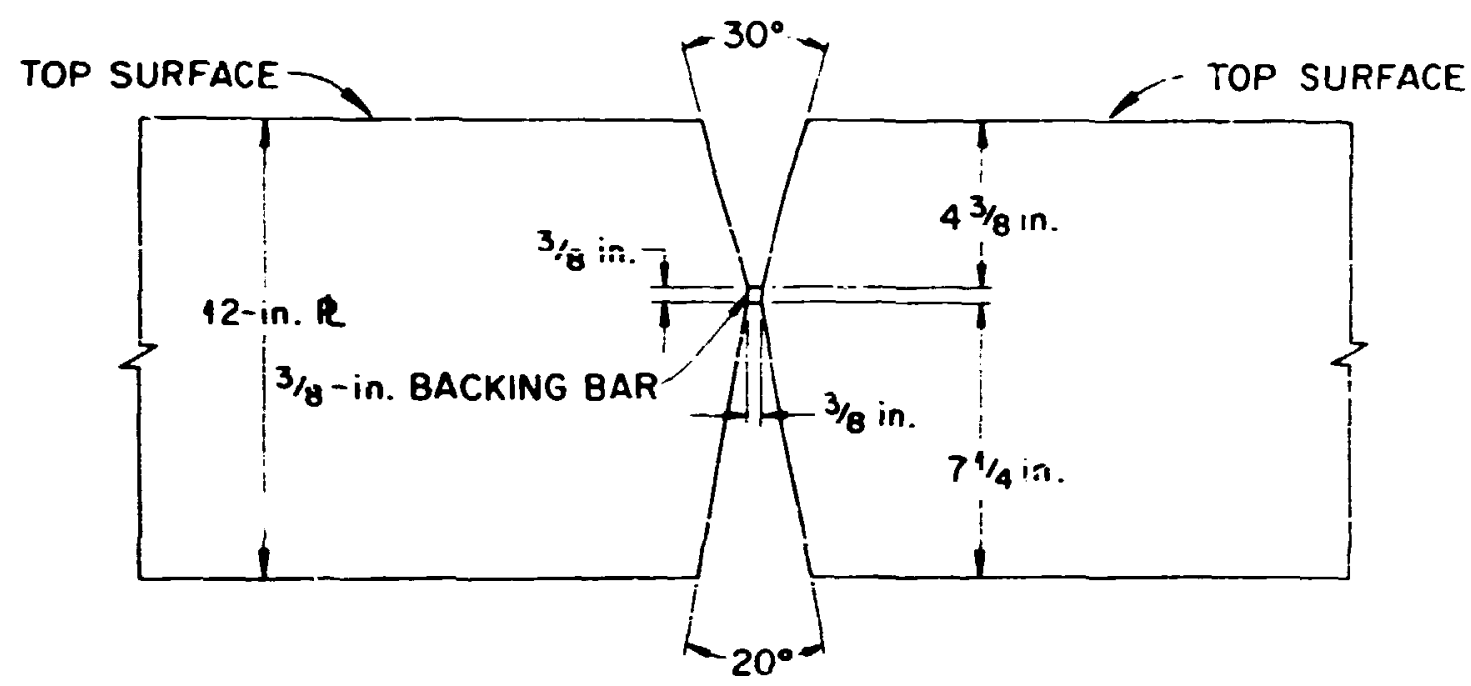

Fiz. 2.2, Joint Preparation for Shiclded-Metzl in Weld.
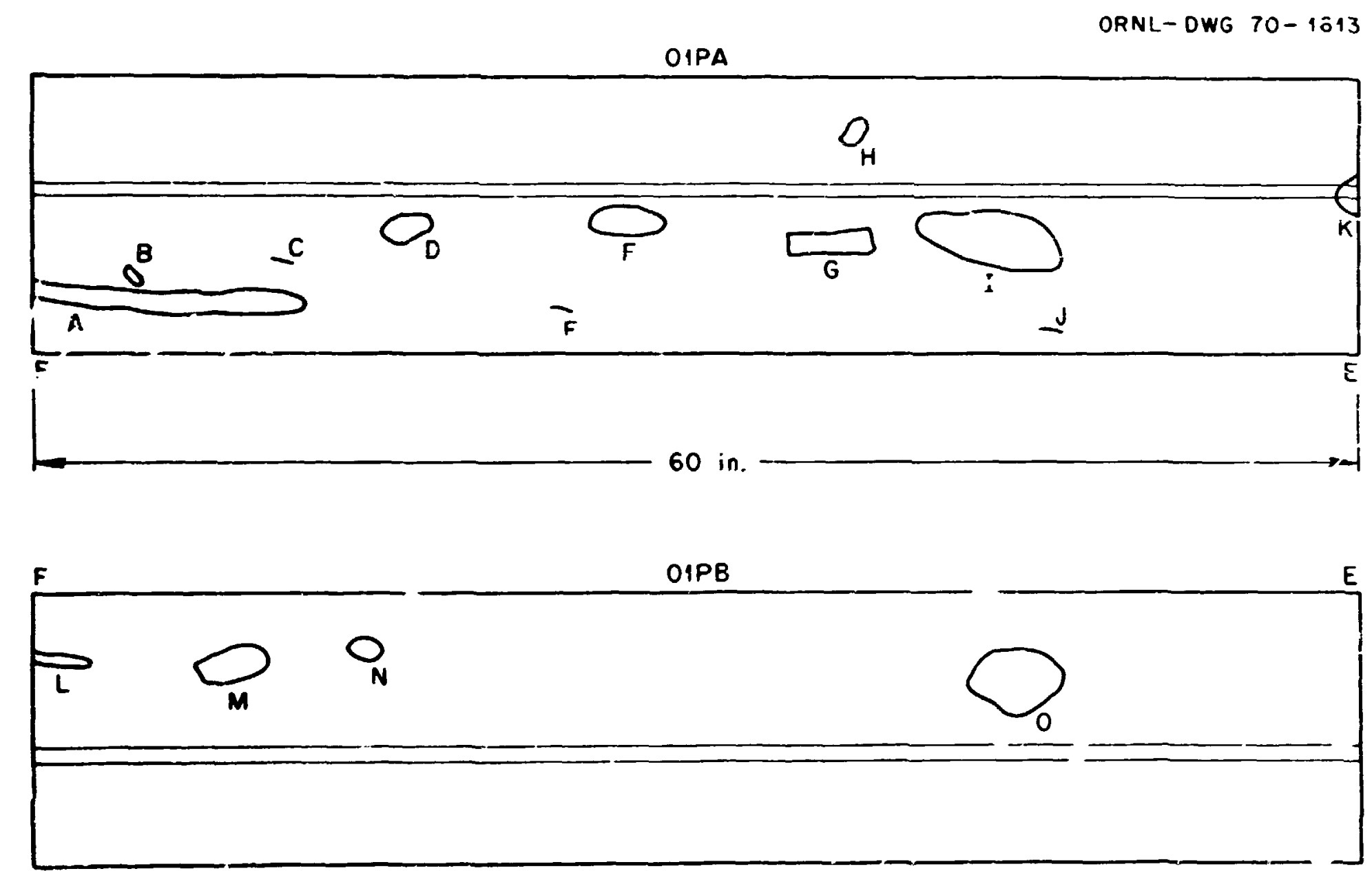

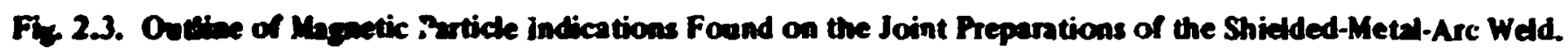



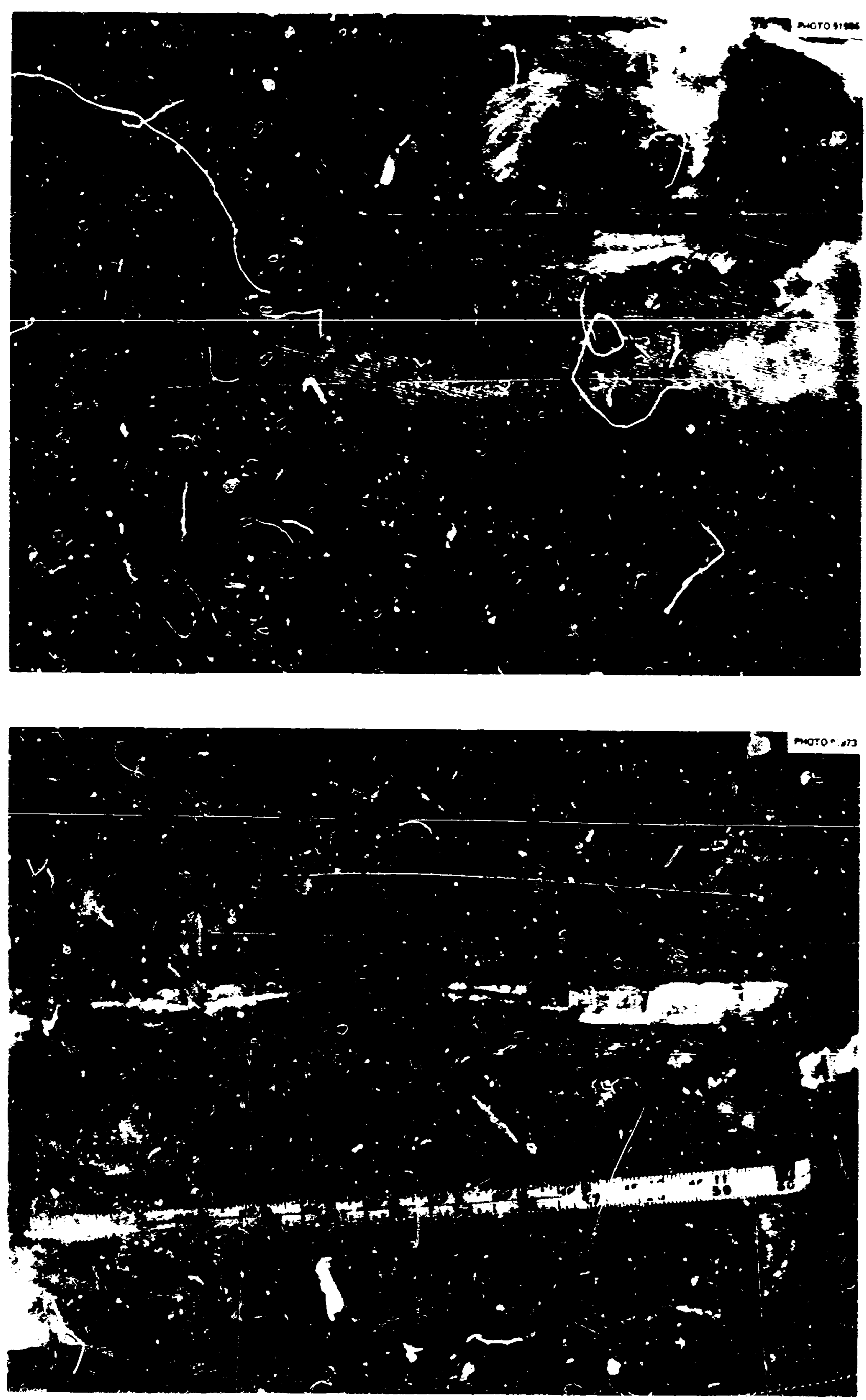

Fig. 2.4. Ton, Magnetic Particte Indications at Area A; Bottom, Area A After Chipping. 


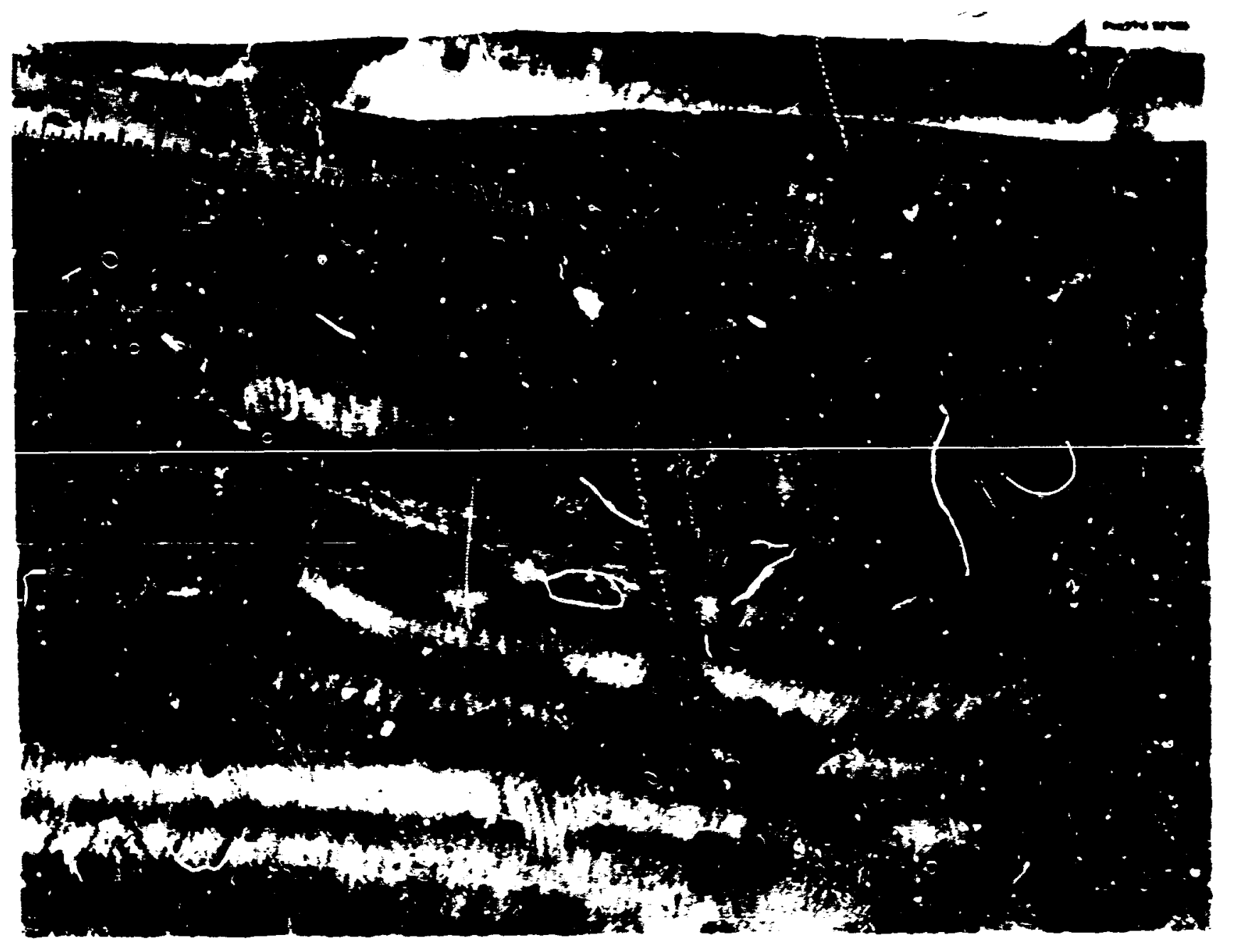

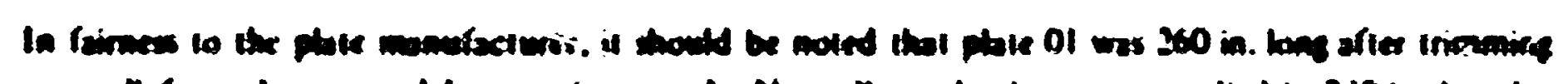

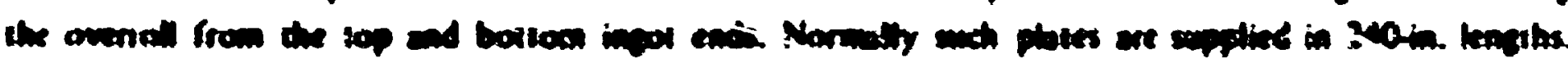

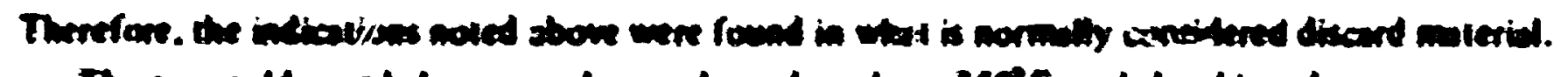

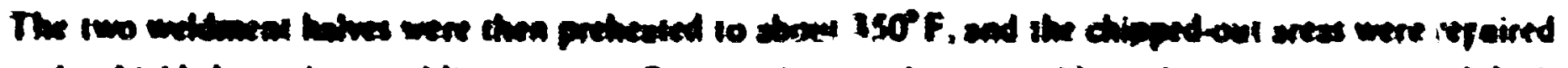

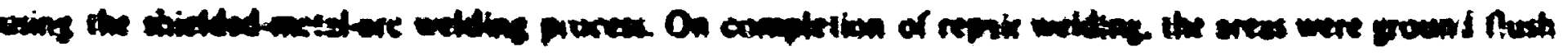

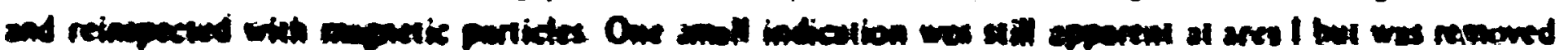

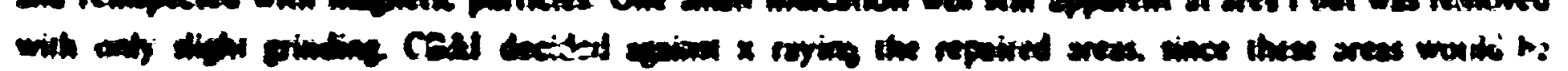

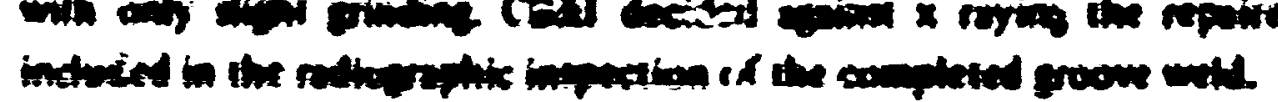

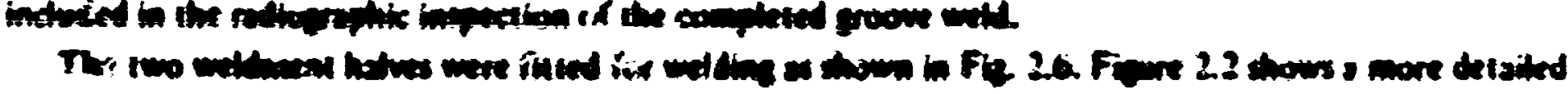

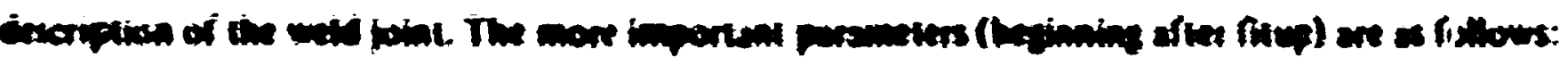

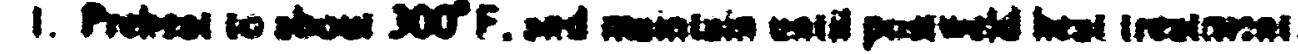

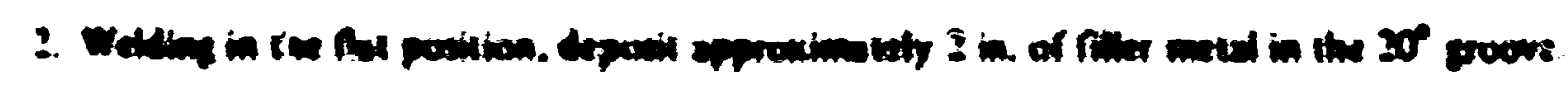

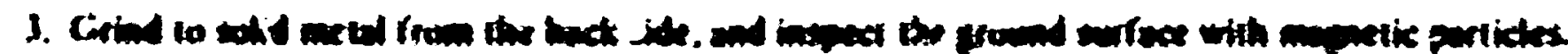

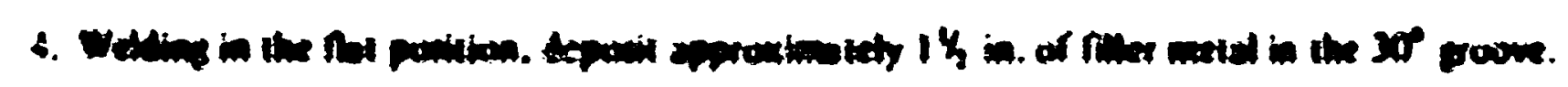

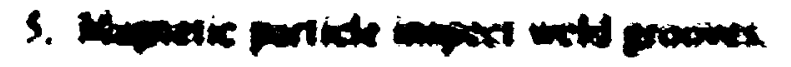

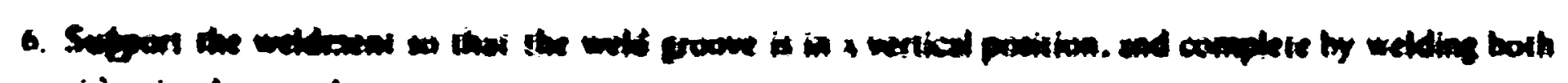

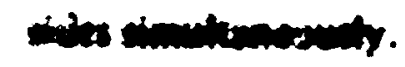
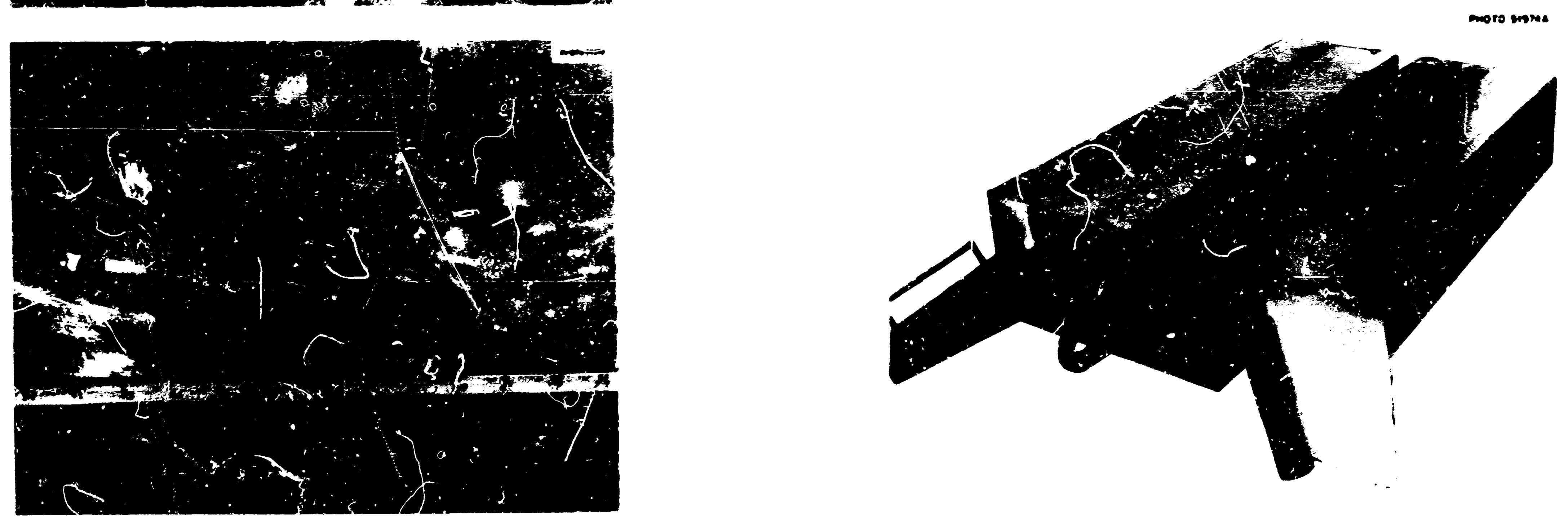

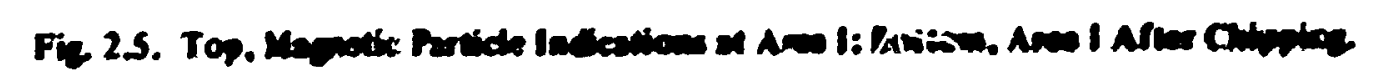


7. Chiraconicaliy inspect lieid white stall hat

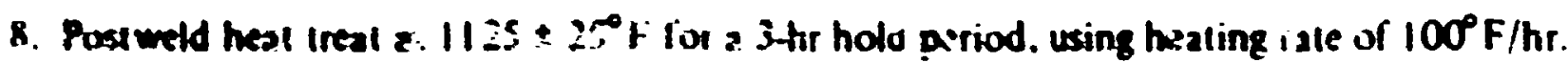

9. Radiogaph.

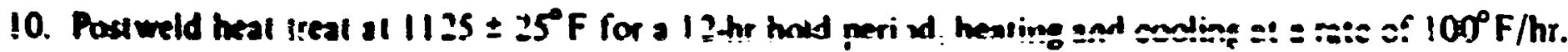

CAst reponted that no "recordable" ultraionic indications were found Juring inspection of the compieted medd. Funther. no imperiections greater than those primilted by Sect. ill for das A nuclear resects were found during radiograpic inspertion.

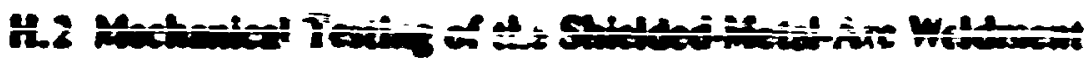

In keepine with the HSST identification system. the shieided-metal-arc weldment thus completed was

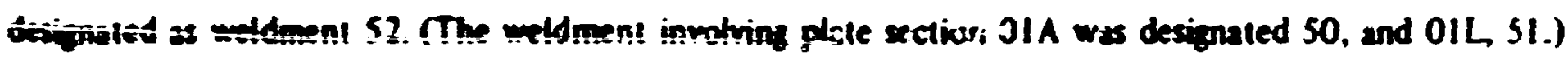
Subeepuently a $20 \mathrm{in}$. section of the weldment comprising $20 \mathrm{ir}$. from the extreme lefthand edse of $01 \mathrm{P}$ and 20 ix. Irom the expreme righthand edge was transmitted to CBal for testing to qualify their weld procedure in scoortance wih Sect IX of the ASME Code. This section of weldment, idenified as 52A, is shom in Fie 2.7.

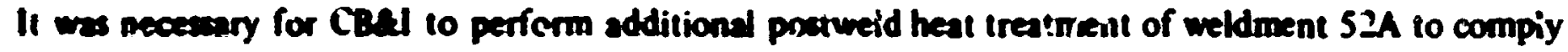
with Farupaph N.S4: I of the ASME Cede ior Nuclear Vewets, Sect. III. This parasraph states in mart: ". . pat weld heat ires' bent of the procedure qualification weid sinil coniorm to the applicable requirements of NS32. The px 2 weld heat treatment time at temperature shall be at leat 80 per cent of the maximum tione to be aptied to the vesel weld material ...." Accordixyly, CBed performed a postweld heat ireatment at $1125 \geq 25^{\circ} \mathrm{F}$ for $35 \mathrm{hr}$. This $35 \mathrm{hr}$ stress relivaf pius the two previous $(3 \mathrm{and} 12 \mathrm{hr})$ streswetieving heat intatments applied to the weldment $\mathrm{ms}$ ske a total of $50 \mathrm{hr}$ stresi-relieving time applied

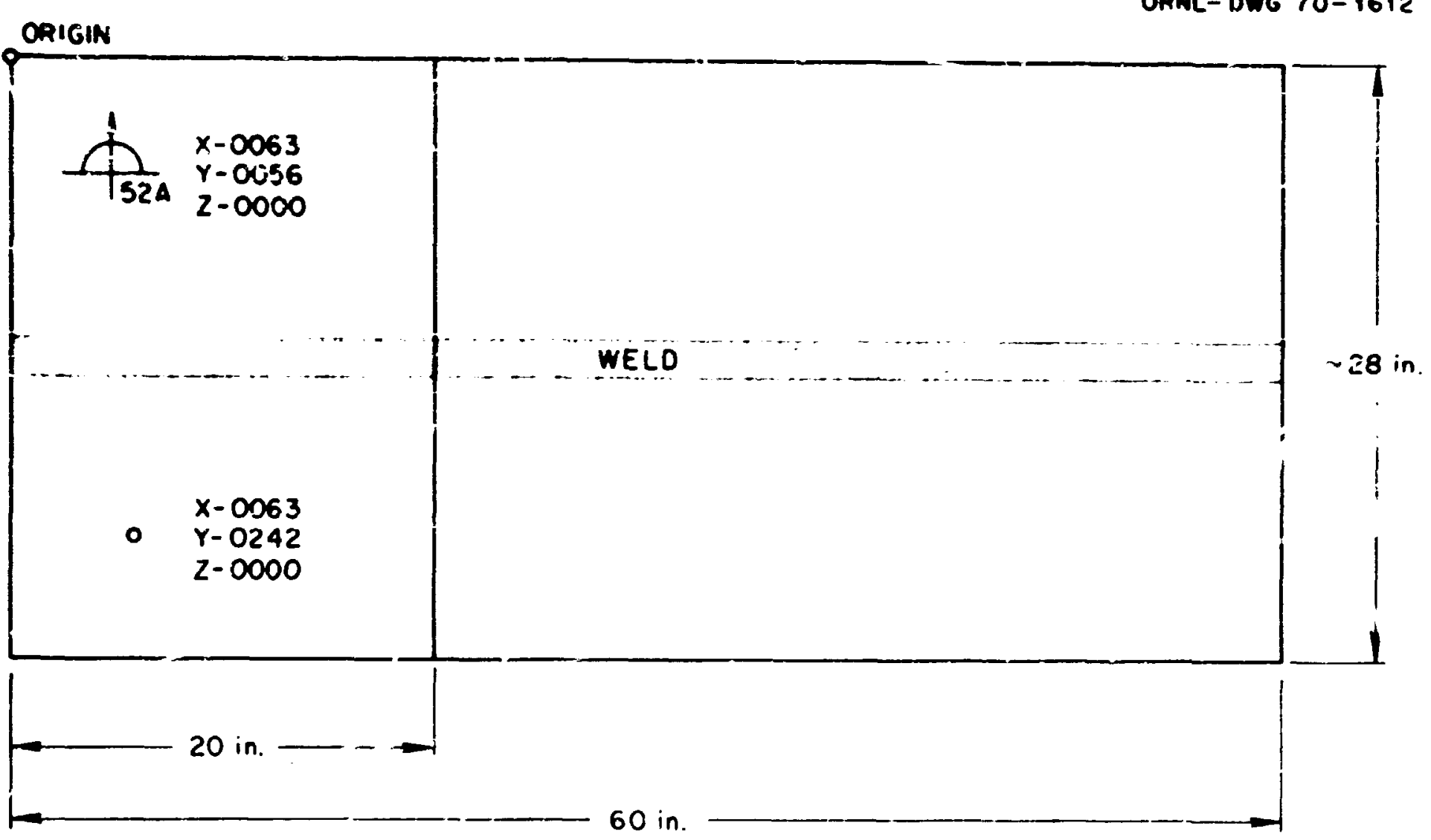

Fig. 2.7. Portion of Weldment Provided to CBA: kos Teatirg. 
by CB\&. (A 40hr stress-relieving heat treatmen. was applied to the base plate by Combust on Engir:eering.)

To qualify a weld procedure to Sect. IX of the Code, certain destructive tests such as guided bend and iensicn tests are recpired. CB\&I performed these tests as well as a number of others. A complete listing of the tests periormed and the specimen numbers of earit follows:

1. Twetve reduced-section (weld metal) tensile sperimens, !W 1 -1 through IW1-6 and 1 W2-1 through $1 \mathrm{~W} 2-6^{3}$

2. Thirty-wo (weld metal) sidebend specimens, 2W1-1 through 2W1-8, 2W2-1 through 2W2-8, 2W3-1 through 2W3-8, and 2W4-1 through 2W4-8.

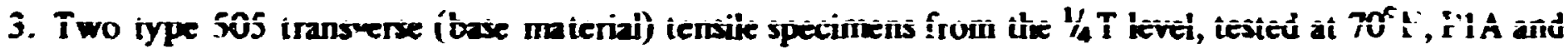
P1B.

4. Four type 505 transverse (base material) tensile specimens from the $y_{4} \mathrm{~T}$ level, tested at $650^{\circ} \mathrm{F}, \mathrm{P3C}-\mathrm{R}$, P3D.:, P3C. and D?D.

5. Two type 505 (weld metal) tensile specimens from the $1 / 4 \mathrm{~T}$ kevel at $70^{\circ} \mathrm{F}$, W1A and W/B.

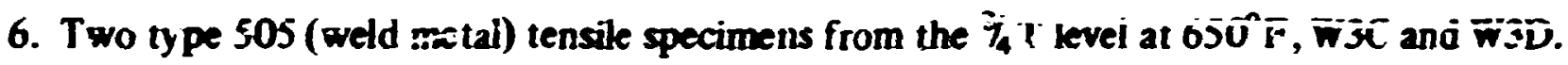

7. Twenty +wo lengitudinal íbase metai) CVN specimens. SP1-1 through 5P1-12 at 1/4T and 5P3-1 through SP3-10 it $3 / 4$.

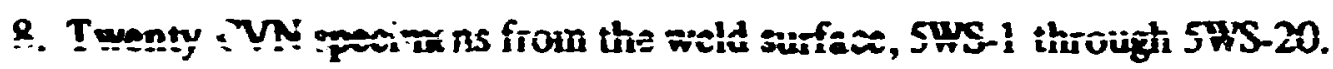

9. Twenty CVN speciriens from the HAZ, SH1-1 through $5 \mathrm{H} 1-12$ at $1 / 4 \mathrm{~T}$, and $5 \mathrm{H} 3.1$ through $5 \mathrm{H} 3.8$ ai $3 / 4 T$

10. Six (itase metal) P-2 drop weight specimens, $6 \mathrm{P} 1-1$ through $6 \mathrm{P} 1.2$ at $1 / 4 \mathrm{~T}$, and $6 \times 3.1$ through $6 \mathrm{P3} .3$ at $y_{4} T$.

11. Six (weld metal) P-2 drop weight specimens, 6W1-1 through 6W1-3 (subsurface top), and 6W?-1 through óW3-3 (subsurface boitom).

12. Six P. 2 drop weigit: specimens from the HAZ, $6 \mathrm{H1}-1$ througn oH1 -3 at $1 / 4 \mathrm{~T}$, and $6 \mathrm{H} 3-1$ through $6 \mathrm{H} 3-3$ at $3 / 4$.

The general location of the test specimere 'within weldment 52A is shown in Fig. 2.8. The next three figures, 2.9, 2.10, and 2.11, shew the specific loration of test specimens in blocks 1,2 , and 3 respectively.

As noied in Fig. 2.9, all of the bend te $3 t s$ were $190^{\circ}$ side bends. E3ch was reyorted as being acceptable, based on the requirements of Sect. IX.

The Charpy V-notch test data compiled from weld metal specimens are listed in Table 2.1 and plotted in Fig. 2.12. The Charpy V-notch test data compiled from heat affected züle (HAZ) and base metal specimens are listed and plotted in Table 2.2 and Fig. 2.13 and in Tabie 2.3 and Fig. 2.14 respectively.

Data from tensile test specimens are listed in Tables 2.4 and 2.5. Drop weight test data are lizted in Table 2.6.

A photomazrograph of a 12-in.-thick crnes section of the weld is shown in Fig. 2.15.

\footnotetext{
${ }^{3}$ Location of inclivicual specimens is described in sabsequent paragraphs and figures.
} 


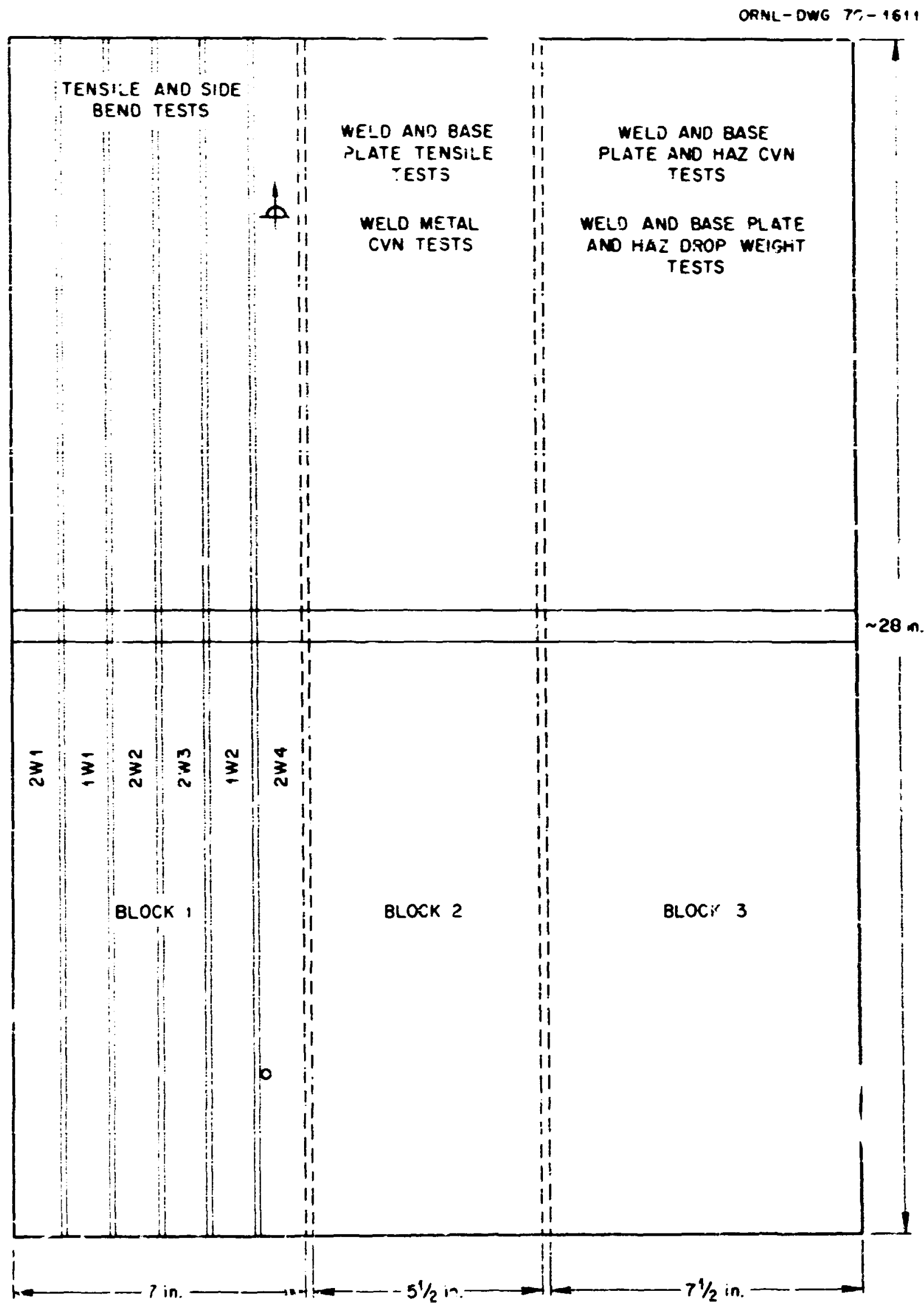

Fig. 2.8. General Location of Teat Specimens in Weldment 52A. 


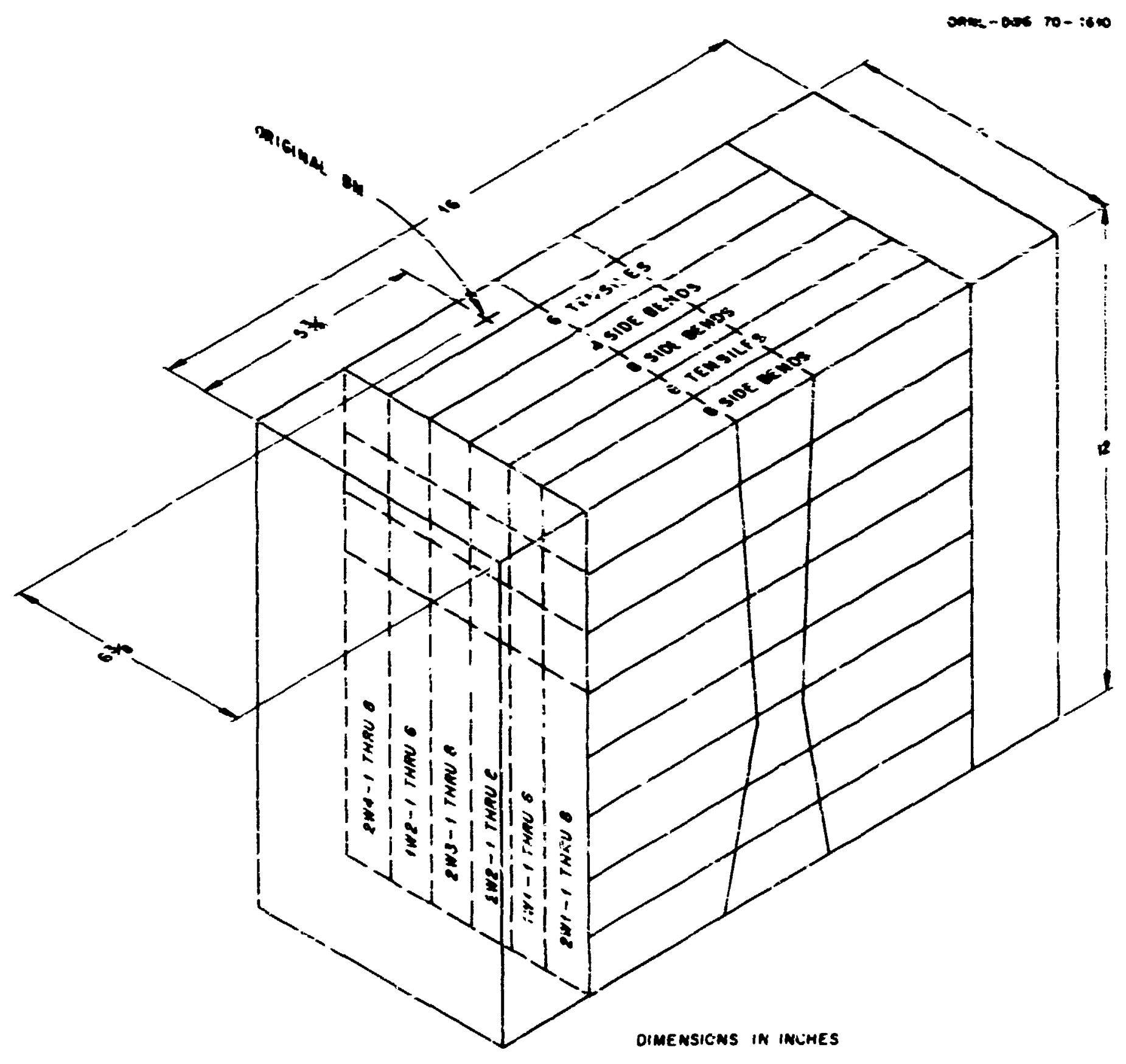

Fie 2.9. Orientution of Teut Speciness in Blosk 1. 


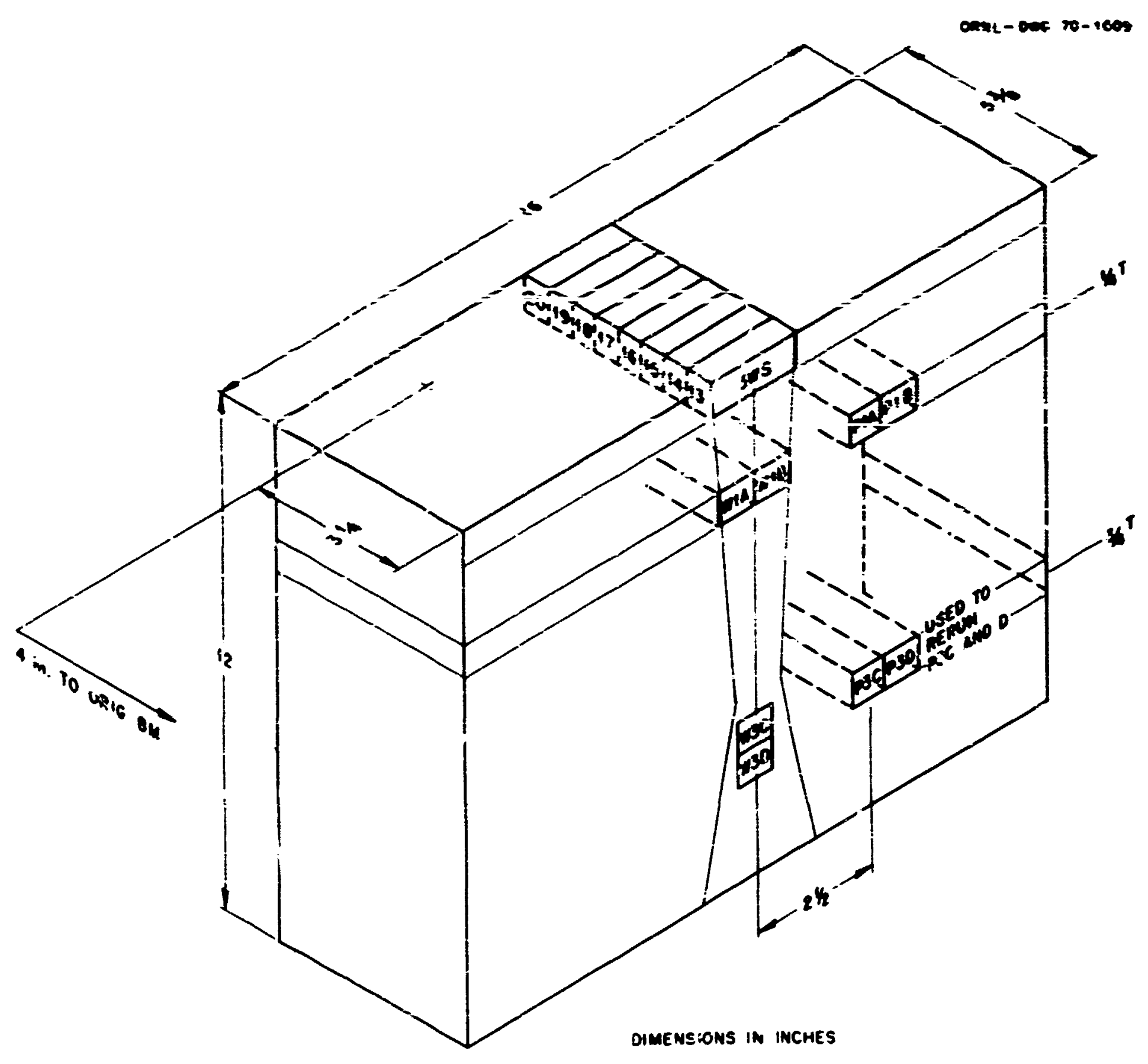

Fie 2.17. Orientation of Trut Specimens in Block 2. 


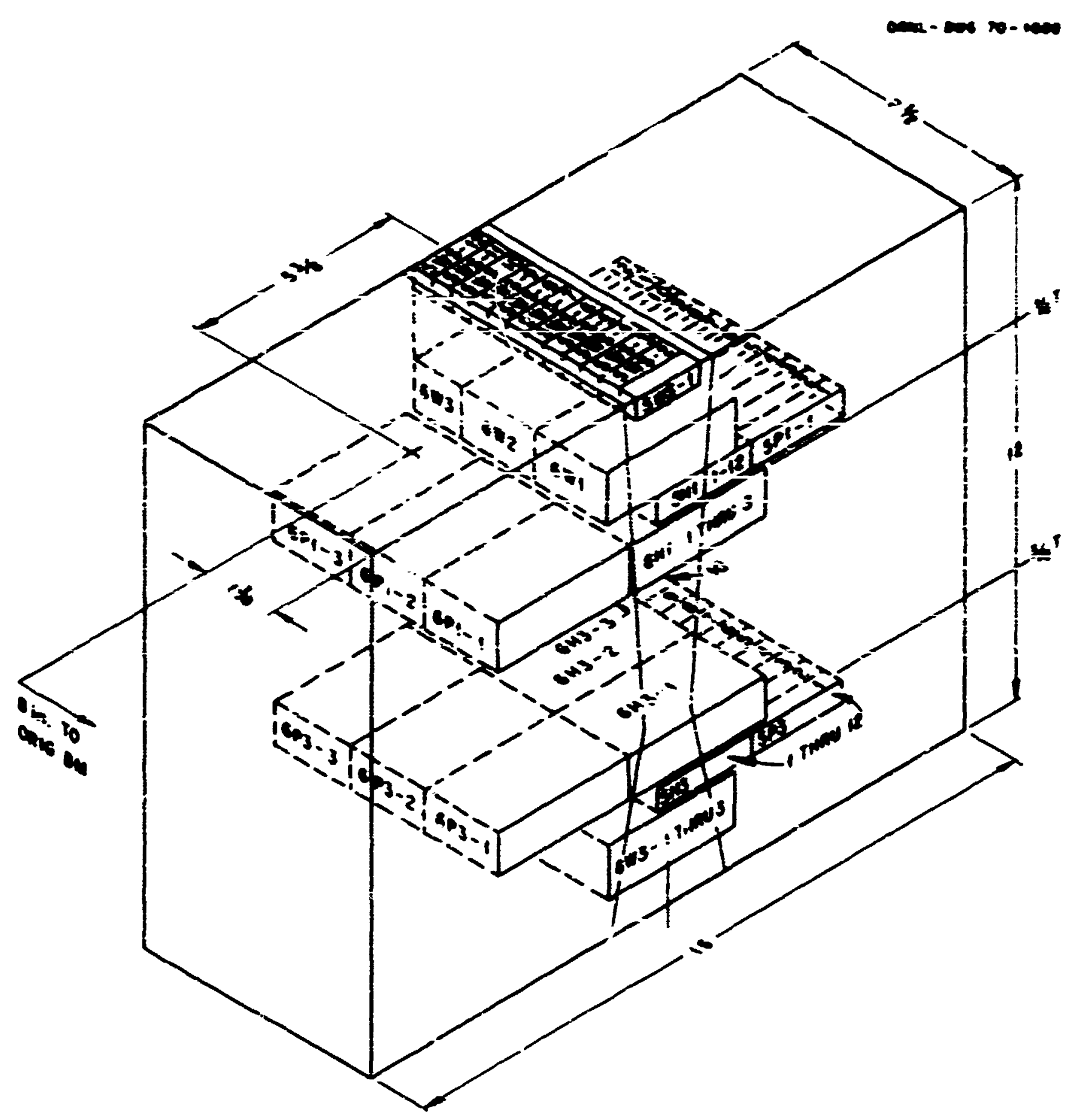

Fiz. 2.11. Orimation of Ten Spacinems in Block 3.

\section{H.3 Fabrication and Weldins of the Sibmened-Are Weldments}

Cnmbistion Engineering, Inc., of Chattannoga, Tennesue, was selected to fabricate four subrm rged-arc weldments from HSST plate 01 edge material. The wo:k wis peformed on two sepiate orders; $h$ wwever, each sperified: "The Seller shall prepare, inspect, and weld the plates in accordance with Seller's current fabrication practice for class A ni:-lear vescels fubricated under Section IIs. . . Preweld heat treatment, in'erp ass temperature, welding, necersary weld ung repairs, pust heat treatment, stress-relief conditions, arid frnal inspection shall be representative of Seller's production conditions."

is noted above, four submerged-arc weldments were purchased, each fatricated essentially alike (except for postweld heat treatment time). At this writing, mrchanical properties data are availanle for only one of these weldments, weldment 51 , made from plate section $01 \mathrm{~L}$. Therefore, this report $w ! l l$ deal with the specifics of weidment 51. 


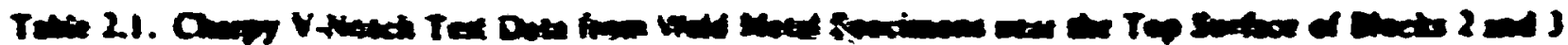

\begin{tabular}{|c|c|c|c|c|c|c|c|}
\hline \multirow{2}{*}{ Sprimen } & \multirow{2}{*}{ Thidex } & \multicolumn{2}{|c|}{ Ormanding } & \multirow{2}{*}{ 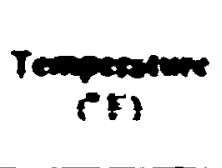 } & \multirow{2}{*}{ inds } & \multirow{2}{*}{ Eximed } & \multirow{2}{*}{ Prom } \\
\hline & & (acted & Dint & & & & \\
\hline sus-1 & Tos wares & 0.344 & a.315 & +10 & 101.5 & is & as \\
\hline Sus? & Tap mistere & 0.393 & 0.315 & +10 & $\infty$ & $\omega$ & 35 \\
\hline $505-3$ & $T e \rightarrow-100$ & 0.393 & a.sis & $\cdot 10$ & $*$ & $n$ & 6 \\
\hline suses & Tep enstux & $a x$ & 0.315 & +4 & lons & $m$ & is \\
\hline suses & Tap nater & ass & a.sis & $\infty$ & 111 & 5 & 0 \\
\hline susts & Top & 3.31 & a.sis & Nat & 117 & $\boldsymbol{n}$ & 8 \\
\hline 5 s. $\overline{7}$ & Tes wives & प. & cosis & $19: 8$ & $: 4$ & 9 & 199 \\
\hline suste & $T \omega=6 x$ & est: & 2.315 & $\cdot 212$ & 13 & 95 & 10 \\
\hline Sus-9 & $T \varphi p=x$ & a.3. & $0 . j 15$ & 59 & $7 \$ 3$ & 63 & 4 \\
\hline 5 wit & Tep whes & ase & 0.315 & $=\$ 0$ & 4 & $\pi$ & is \\
\hline $5 T-11$ & Top entice & 0.393 & 0.215 & $\mathbf{0}$ & eq1: & 73 & $\boldsymbol{s}$ \\
\hline $50+12$ & Top mortace & 0.393 & 0.913 & a & 4 & 63 & 50 \\
\hline 5 S.13 & Top anteos & oys & a.is & -103 & iz7 & 93 & 105 \\
\hline $5 \times 14$ & Top maxe & a.ses & a.115 & +163 & $1 ! 8$ & 9 & $s$ \\
\hline SWE-15 & Top natece & assis & P..115 & +2 & 1013 & $x$ & $\boldsymbol{s}$ \\
\hline sus-16 & Top eriace & $=39$ & $33 ! s$ & -20 & 15.6 & 73 & $\omega$ \\
\hline $5 x=17$ & Tep erifue & 0.344 & $n 115$ & -28 & 74.5 & 63 & 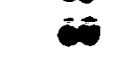 \\
\hline $5 w 5-18$ & Top antere & 0.384 & 0.315 & -30 & 22 & 67 & $n$ \\
\hline 505is & iop & a 305 & 0.315 & -75 & $x$ & 23 & 10 \\
\hline 5 sis & Top untece & 0.393 & 0.315 & -75 & 23 & 22 & 16 \\
\hline
\end{tabular}

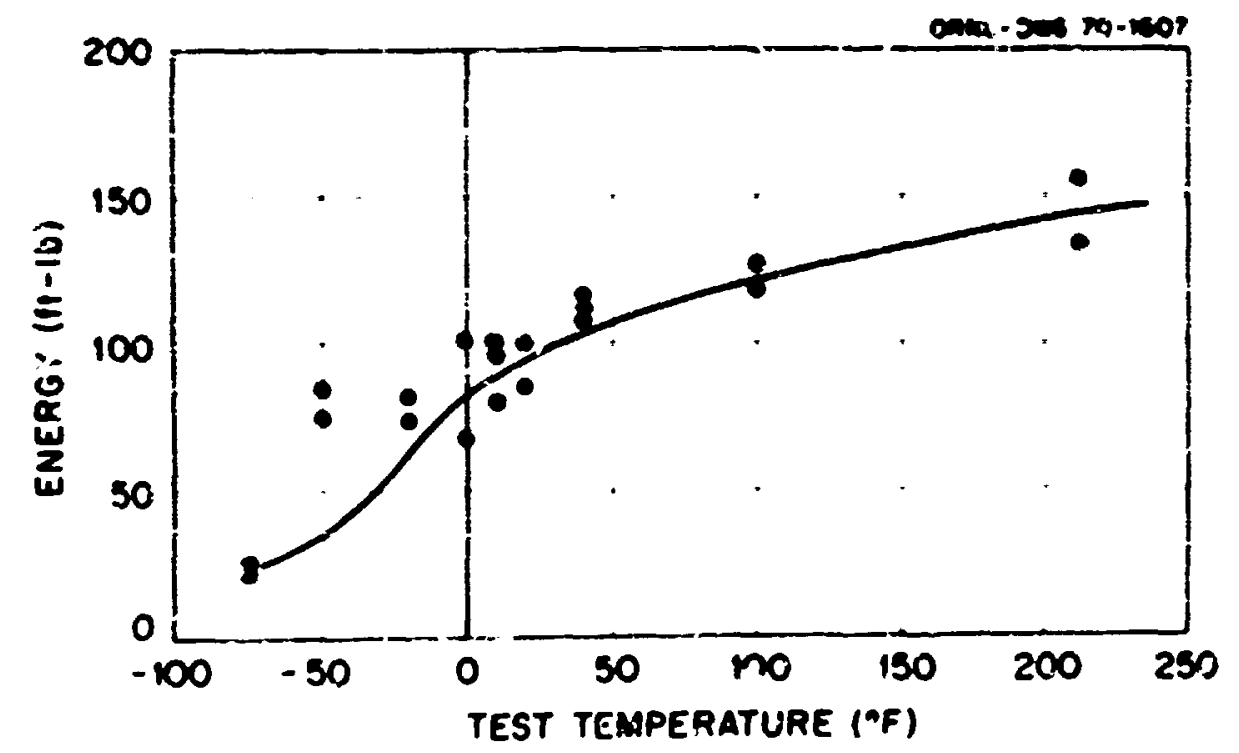

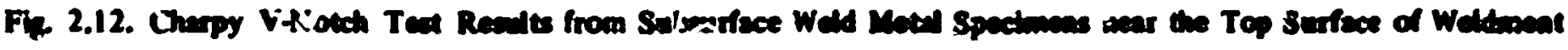
S2A. 


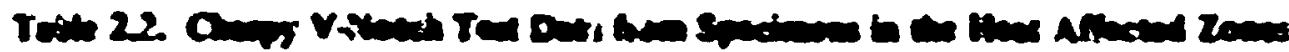

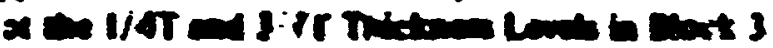

\begin{tabular}{|c|c|c|c|c|c|c|c|}
\hline \multirow{2}{*}{ 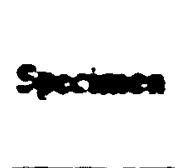 } & \multirow{2}{*}{ Intion } & \multicolumn{2}{|c|}{ 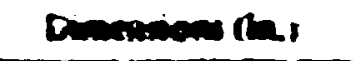 } & \multirow{2}{*}{ 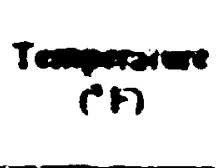 } & \multirow{2}{*}{ Entor } & \multirow{2}{*}{ 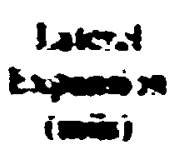 } & \multirow{2}{*}{$\begin{array}{l}\text { Pucent } \\
\text { Sinear }\end{array}$} \\
\hline & & (axpend & Dopa & & & & \\
\hline stt-1 & I:T & 8.5.5: & 0.315 & $>10$ & 28.5 & \&s & 45 \\
\hline 541.3 & I/NT & 0.394 & a.315 & +10 & 74 & 63 & 45 \\
\hline sH1.3 & $\operatorname{lin} \pi$ & a.sen & 9.315 & +10 & Ss & 50 & 35 \\
\hline stil 4 & $I / 4 T$ & 0.34 & 0.315 & -10 & 12 & 69 & ss \\
\hline sall-s & I/AT & 0.34 & 0.315 & 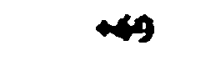 & exs & $\mathbf{\omega}$ & 60 \\
\hline sult & int & ay? & ojis & $\infty 0$ & 70 & $\$ 1$ & sn \\
\hline seti.7 & INAY & agst & $22: 5$ & $+2: 2$ & i5j & $\hat{x i}$ & 100 \\
\hline silt & IieT & 0.54 & 0.31s & $\therefore 212$ & 138 & 8 & 100 \\
\hline SHI-9 & I/AT & 0.333 & $0.3: 5$ & -50 & 10 & 37 & 20 \\
\hline stil-10 & $1 / \sigma T$ & 0.325 & 0.315 & -50 & 27 & 25 & 20 \\
\hline sH1-11 & INTT & 0.343 & 0.315 & 0 & $\leq 8$ & $\$ ?$ & 30 \\
\hline $\sin 1-12$ & I/AT & a. 300 & 0.315 & 0 & $\pi$ & 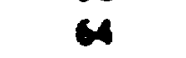 & 45 \\
\hline $5: 131$ & YAT & ase & 0.315 & -75 & 13.5 & 16 & 10 \\
\hline SH3-2 & WuT & a.s.s & 0.315 & -75 & 24 & 24 & is \\
\hline $\mathrm{sec}^{3}$ & $3 / 45$ & 0.34 & 0.315 & -20 & is & 43 & 30 \\
\hline S4: & T4:TT & a.s & 0.315 & -20 & 53 & 45 & 30 \\
\hline stu-s & $3,4 T$ & a.34 & a.3:5 & +20 & 635 & 56 & SO \\
\hline stiss & BHAT & a.394 & 0.315 & +20 & $5: 3$ & 69 & 60 \\
\hline SHE? & $y x$ & a.294 & 0.315 & 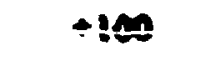 & $: 1: 5$ & $3 !$ & 10 \\
\hline SH3 & HST & 0.393 & 0.315 & +100 & i1s & 90 & 100 \\
\hline
\end{tabular}

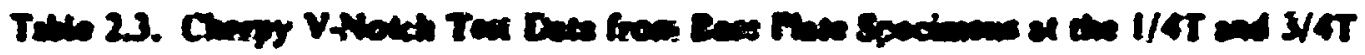

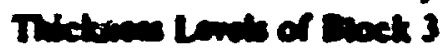

\begin{tabular}{|c|c|c|c|c|c|c|c|}
\hline \multirow[b]{2}{*}{ Spacionson } & \multirow{2}{*}{$\begin{array}{l}\text { Trickness } \\
\text { Level }\end{array}$} & \multicolumn{2}{|c|}{ Dimangon (in) } & \multirow{2}{*}{$\begin{array}{c}\text { Teopgerature } \\
(F)\end{array}$} & \multirow{2}{*}{$\begin{array}{l}\text { Enery } \\
(1,+1)\end{array}$} & \multirow{2}{*}{$\begin{array}{l}\text { Lameral } \\
\text { Exponion } \\
\text { (mils) }\end{array}$} & \multirow{2}{*}{$\begin{array}{l}\text { Percent } \\
\text { Stica: }\end{array}$} \\
\hline & & $\begin{array}{l}\text { Wadth } \\
\text { (xctud) }\end{array}$ & Depth & & & & \\
\hline SPI-1 & $1 ! 4 T$ & 0.393 & $0.3 i 5$ & +111 & 70.5 & 57 & 35 \\
\hline $5 P 1-2$ & I/AT & 0.393 & 0.315 & +10 & 50.5 & 44 & 23 \\
\hline SPI-3 & I/AT & 0.394 & 0.315 & +10 & 50.5 & 4 & 25 \\
\hline SPl: & $1 / 4 T$ & 0.394 & 0.383 & +40 & 34.5 & $7 j$ & so \\
\hline$S t 1.5$ & I/AT & $0.3 r$ & 0.315 & +40 & 70 & 60 & 35 \\
\hline SPI-6 & $1 / 4 T$ & 0.394 & 0.315 & +40 & 62.5 & 53 & 30 \\
\hline SP1-7 & $1 / 4 T$ & 0.394 & 0.315 & +212 & 138.5 & 95 & 100 \\
\hline SPi-8 & $1 / 4 T$ & 0.395 & 0.315 & +212 & 139 & 92 & 100 \\
\hline SP1-9 & $1 / \div 5$ & 0.393 & 0.315 & -50 & 13.5 & is & 0 \\
\hline SPI-10 & $1 / 4 T$ & 0.394 & 0.315 & $-5 c$ & 29 & 25 & 5 \\
\hline SP1-11 & $1 / 4 T$ & 6.394 & 0.315 & 0 & 21 & 2ิ2 & 15 \\
\hline $5 P 1.12$ & $1 / 4 T$ & 0.394 & 0.315 & $\mathbf{0}$ & 56.5 & 47 & 30 \\
\hline SP3-1 & $3 / 4 T$ & 0.393 & 0.315 & -75 & 6 & 7 & 0 \\
\hline $5 P 3-3$ & $3 / 4 T$ & 0.393 & $n \geq 15$ & -75 & 4 & 2 & 0 \\
\hline $5 P 34$ & $3 / 4 T$ & 0.393 & 0.315 & -20 & 47 & 40 & 15 \\
\hline 5P3-5 & $3 / 4 T$ & 0.394 & 0.315 & -20 & 37.5 & 40 & 10 \\
\hline $5 P 3-6$ & $3 / 4 T$ & 0.393 & 0.315 & +20 & 63 & 54 & 25 \\
\hline $5 P 3-8$ & $3 / 4 T$ & C.393 & 0.315 & +20 & 60.5 & 51 & 25 \\
\hline 5P3-9 & $3 / 4 T$ & 0.393 & $0.311^{-}$ & ن & 102.5 & 80 & 70 \\
\hline SP3-10 & $3 / 4 T$ & 0.394 & 0.315 & +100 & 123 & 85 & 85 \\
\hline
\end{tabular}




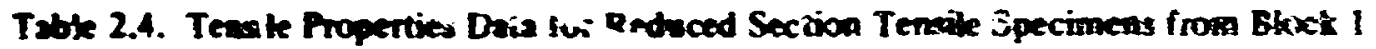

\begin{tabular}{|c|c|c|c|c|c|c|c|c|c|}
\hline \multirow{2}{*}{ Sperimen } & \multicolumn{2}{|c|}{ Dimensions (in) } & \multirow{2}{*}{$\begin{array}{l}\text { Area } \\
\text { iin. }^{2} \text {, }\end{array}$} & \multirow{2}{*}{$\begin{array}{c}\text { Yield } \\
\text { Suenetil } \\
\text { (Ib) }\end{array}$} & \multirow{2}{*}{$\begin{array}{c}\text { Tencile } \\
\text { Streneth } \\
\text { (b) }\end{array}$} & \multirow{2}{*}{$\begin{array}{l}\text { Yield } \\
\text { Strength } \\
\text { (psi) }\end{array}$} & \multirow{2}{*}{$\begin{array}{l}\text { Urimate } \\
\text { Tersike } \\
\text { Strength } \\
\text { (psi) }\end{array}$} & \multirow{2}{*}{$\begin{array}{c}\text { Elones:ion } \\
\text { in } 2 \text { inch } \\
\text { Gage } \\
(x)\end{array}$} & \multirow{2}{*}{ Remarks } \\
\hline & with & Thickness & & & & & & & \\
\hline$|W| \cdot \mid$ & 1.003 & 1.810 & 1.815 & 125.200 & $i 52.800$ & 69.000 & 84.100 & 52.5 & Weld fracture \\
\hline ini-2 & 1.000 & 1.840 & i.840 & 129.800 & 156.400 & 70.500 & 84.500 & 36 & Piate fracture \\
\hline$|w|-3$ & 2.995 & 1.863 & 1.852 & 132,000 & 155.100 & 71,200 & 83.800 & 37.5 & Pute fracture \\
\hline$|N| A$ & 0.990 & 1.906 & 1.885 & 133.000 & 156,200 & 70.550 & 83,900 & 38.5 & Plate fractire \\
\hline$|W|-5$ & 0.986 & 1.814 & 1.788 & 126,200 & 147,900 & 70,700 & 82.800 & 39 & Fate faxture \\
\hline $1 \times 16$ & 0.983 & 1.859 & 1.826 & 134.000 & 152.900 & 23.400 & 83.200 & 32.5 & Pate fracture \\
\hline $182-1$ & 1.036 & 1.885 & 1.920 & 140,890 & $: 64,400$ & 73,300 & 85,700 & 52.5 & Weld fracture \\
\hline ?:2-2 & 1.035 & 1.956 & 1.990 & 144,800 & 172.700 & 72,700 & 86,800 & 52 & Weld fracture \\
\hline $1 W 2-3$ & 1.034 & 1.875 & $1.9: 0$ & 130,500 & 163.200 & 68,400 & 85.500 & 41 & Plate fracture \\
\hline 1994 & 1.034 & 1.840 & 1.872 & 125,500 & 158.500 & 67.000 & 84.500 & 42 & Plate fracture \\
\hline $1 \times 2.5$ & 1.034 & 1.895 & 1.960 & 130.200 & 164,600 & 66.400 & 84,000 & 40 & Olate frs ture \\
\hline $1 \times 26$ & 1.032 & 1.730 & 1.760 & 130200 & 152,200 & 74,900 & 86.500 & 38 & Pate fracture \\
\hline
\end{tabular}

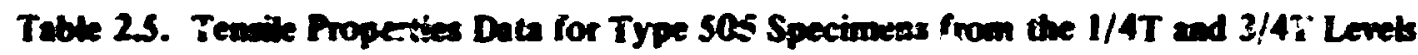
in the Weld aed Bare Metel of Block 2

\begin{tabular}{|c|c|c|c|c|c|c|c|c|c|c|c|}
\hline \multirow[t]{2}{*}{ Specimen } & \multirow{2}{*}{$\begin{array}{l}\text { Thickneass } \\
\text { Level }\end{array}$} & \multirow{2}{*}{$\begin{array}{c}\text { Diameter. } \\
\text { Actual } \\
\text { (ir..) }\end{array}$} & \multirow{2}{*}{$\begin{array}{c}\text { Area } \\
\text { (in. }{ }^{2} \text { ) }\end{array}$} & \multirow{2}{*}{$\begin{array}{l}\text { Yield } \\
\text { Strength } \\
\text { (Ib) }\end{array}$} & \multirow{2}{*}{$\begin{array}{l}\text { Tensik } \\
\text { Strength } \\
\text { (lb) }\end{array}$} & \multirow{2}{*}{$\begin{array}{c}\text { Yield } \\
\text { Strength } \\
\text { (pai) }\end{array}$} & \multirow{2}{*}{$\begin{array}{l}\text { Uilfimate } \\
\text { reasile } \\
\text { jtrength } \\
\text { (Dsi) }\end{array}$} & \multicolumn{2}{|c|}{$\begin{array}{l}\text { Reciuction } \\
\text { in Area }\end{array}$} & \multirow{2}{*}{$\begin{array}{c}\text { Elongation } \\
\text { in } 2 \text { inch } \\
\text { Gape } \\
\text { (x) }\end{array}$} & \multirow{2}{*}{$\begin{array}{c}\text { Test } \\
\text { Temperatuse } \\
\text { PF) }\end{array}$} \\
\hline & & & & & & & & in. & $x$ & & \\
\hline $\begin{array}{l}\text { PIA } \\
\text { PIB }\end{array}$ & $\begin{array}{l}1 / 4 T \\
1 / 4 T\end{array}$ & $\begin{array}{l}0.499 \\
0.500\end{array}$ & $\begin{array}{l}0.1955 \\
0.1963\end{array}$ & $\begin{array}{l}12,600 \\
12,600\end{array}$ & $\begin{array}{l}16,900 \\
16,850\end{array}$ & $\begin{array}{l}64,500 \\
64,200\end{array}$ & $\begin{array}{l}86,500 \\
86,000\end{array}$ & $\begin{array}{l}15 / 16 \\
1-1 / 8\end{array}$ & $\begin{array}{l}55.5 \\
66.8\end{array}$ & $\begin{array}{l}21.5 \\
25\end{array}$ & $\begin{array}{l}70 \\
70\end{array}$ \\
\hline $\begin{array}{l}\text { P3C-R } \\
\text { P3D-R }\end{array}$ & $\begin{array}{l}3 / 4 T \\
3 / 4 T\end{array}$ & $\begin{array}{l}0.497 \\
0.496\end{array}$ & $\begin{array}{l}0.1740 \\
0.1932\end{array}$ & $\begin{array}{l}10.558 \\
10,550\end{array}$ & $\begin{array}{l}15.150 \\
15.100\end{array}$ & $\begin{array}{l}\$ 4,400 \\
54,600\end{array}$ & $\begin{array}{l}78,100 \\
78,100\end{array}$ & $\begin{array}{l}1-1 / 16 \\
1 S^{\prime} 16\end{array}$ & $\begin{array}{l}58.5 \\
60.7\end{array}$ & $\begin{array}{l}22.5 \\
22\end{array}$ & $\begin{array}{l}650 \\
650\end{array}$ \\
\hline $\begin{array}{l}\text { WA } \\
\text { WB }\end{array}$ & $\begin{array}{l}1 / 4 T \\
1 / 4 T\end{array}$ & $\begin{array}{l}0.198 \\
0.499\end{array}$ & $\begin{array}{l}0.1947 \\
0.1955\end{array}$ & $\begin{array}{l}13,900 \\
14,100\end{array}$ & $\begin{array}{l}16.850 \\
16.400\end{array}$ & $\begin{array}{l}71,400 \\
72,100\end{array}$ & $\begin{array}{l}86.500 \\
84.000\end{array}$ & $\begin{array}{l}15 / 16 \\
1-1 / 4\end{array}$ & $\begin{array}{l}71.3 \\
71\end{array}$ & $\begin{array}{l}28 \\
25.5\end{array}$ & $\begin{array}{l}70 \\
70\end{array}$ \\
\hline $\begin{array}{l}\text { W3C } \\
\text { w3D }\end{array}$ & $\begin{array}{l}3 / 4 T \\
3 / 4 T\end{array}$ & $\begin{array}{l}0.499 \\
0.497\end{array}$ & $\begin{array}{l}0.1955 \\
0.1940\end{array}$ & $\begin{array}{l}11,600 \\
11,550\end{array}$ & $\begin{array}{l}15,500 \\
15,350\end{array}$ & $\begin{array}{l}54,200 \\
54,400\end{array}$ & $\begin{array}{l}79,330 \\
79,100\end{array}$ & $\begin{array}{l}7 / 8 \\
7 / 8\end{array}$ & $\begin{array}{l}65.1 \\
52.1\end{array}$ & $\begin{array}{l}22 \\
19\end{array}$ & $\begin{array}{l}650 \\
650\end{array}$ \\
\hline
\end{tabular}


Table 2.6. Drop Weight Test Data from the Weld and Base Metal and HAZ in Block •

\begin{tabular}{|c|c|c|c|c|c|c|c|c|c|}
\hline \multirow{2}{*}{ Spe:imen } & \multirow{2}{*}{ Thickness Leve: } & \multicolumn{3}{|c|}{$\begin{array}{l}\text { Sricimen Dimensions } \\
\text { (in.) }\end{array}$} & \multirow{2}{*}{$\begin{array}{c}\text { Jepit } \\
\text { oí } \\
\text { Notch } \\
\text { (in.) }\end{array}$} & \multirow{2}{*}{$\begin{array}{l}\text { Height } \\
\text { of } \\
\text { Drop } \\
\text { (ft) }\end{array}$} & \multirow{2}{*}{$\begin{array}{l}\text { Weight } \\
\text { of } \\
\text { Load } \\
\text { (lb) }\end{array}$} & \multirow{2}{*}{$\begin{array}{c}\text { Test } \\
\text { Temperature } \\
\left.{ }^{\circ} \mathrm{F}\right)\end{array}$} & \multirow[t]{2}{*}{ Results } \\
\hline & & Width & Thickness & Sength & & & & & \\
\hline 6P1-1 & 1/4T Base plate & 2 & $3 / 4$ & 5 & 0.081 & 5 & 60 & +20 & No break \\
\hline $6 \mathrm{Pl}-2$ & 1/4 I Race plate & 2 & $3 / 4$ & 5 & 0.075 & 5 & & $-2 C$ & Break \\
\hline $6 \mathrm{Pl}-3$ & i/4T Base plate & 2 & $3 / 4$ & 5 & $i .073$ & 5 & 60 & 0 & Break \\
\hline 6P3-i & 3/4T Base plate & 2 & $3 ; 4$ & 5 & $': 071$ & 5 & 60 & +20 & No break \\
\hline $6 P 3-2$ & 3/4T Base pite & 2 & $3: 4$ & 5 & ¿:.076 & 5 & 60 & +0 & No break \\
\hline 6933 & 3/4T Dast pla _. & 2 & $3: 4$ & $\subsetneq$ & 0.073 & 5 & 60 & $+i 0$ & ïo break \\
\hline 6́WL-1 & Subsurface top & 2 & $3 / 4$ & 5 & 0.080 & 5 & 60 & +20 & No break \\
\hline$\in W 1-2$ & Subsurface top & 2 & $3 / 4$ & 5 & 0079 & 5 & 60 & 0 & No break \\
\hline $6 W 1-3$ & Subsurface top & 2 & $3 / 4$ & 5 & $0.08 \mathrm{I}$ & 5 & 60 & -50 & No break \\
\hline 6 W3-1 & Subsurface bottcm & 2 & $3 ; 4$ & 5 & 0.074 & 5 & 60 & +20 & No break \\
\hline $6 W 3-2$ & Subsurfacc: bottom & $?$ & $3 / 4$ & 5 & 0.080 & 5 & 60 & -60 & Break \\
\hline $6 \times 3-3$ & Subsurface bottr,m & 2 & $3 / 4$ & 5 & 0.074 & 5 & so & 50 & No break \\
\hline $6 \mathrm{HI}-1$ & $3 / 4 \mathrm{~T} \mathrm{HAZ}$ & 2 & $3 ! 4$ & 5 & 0.079 & 5 & 60 & +20 & No break \\
\hline 6 Fil-2 & $3 / 4 \mathrm{~T} \mathrm{HAZ}$ & 2 & $3 / 4$ & 5 & 0.084 & 5 & 60 & -50 & Break \\
\hline $6 \mathrm{H} !-3$ & 3/4T HAZ & 2 & $3 / 4$ & 5 & 0.074 & 5 & 60 & +10 & No break \\
\hline $6 \mathrm{H}^{3}-1$ & : IT HAZ & 2 & $3 / 4$ & 5 & $0.07 ?$ & 5 & 60 & +20 & No break \\
\hline $6 H 3-2$ & $: / 4 T \mapsto A Z$ & 2 & $3 / 4$ & 5 & 0.076 & 5 & 60 & -10 & No break. \\
\hline $6 \mathrm{H} 3-3$ & $1 / 4 \mathrm{r} H \mathrm{H} ?$ & 2 & $3: 4$ & 5 & 0.076 & 5 & 60 & -10 & No break \\
\hline
\end{tabular}

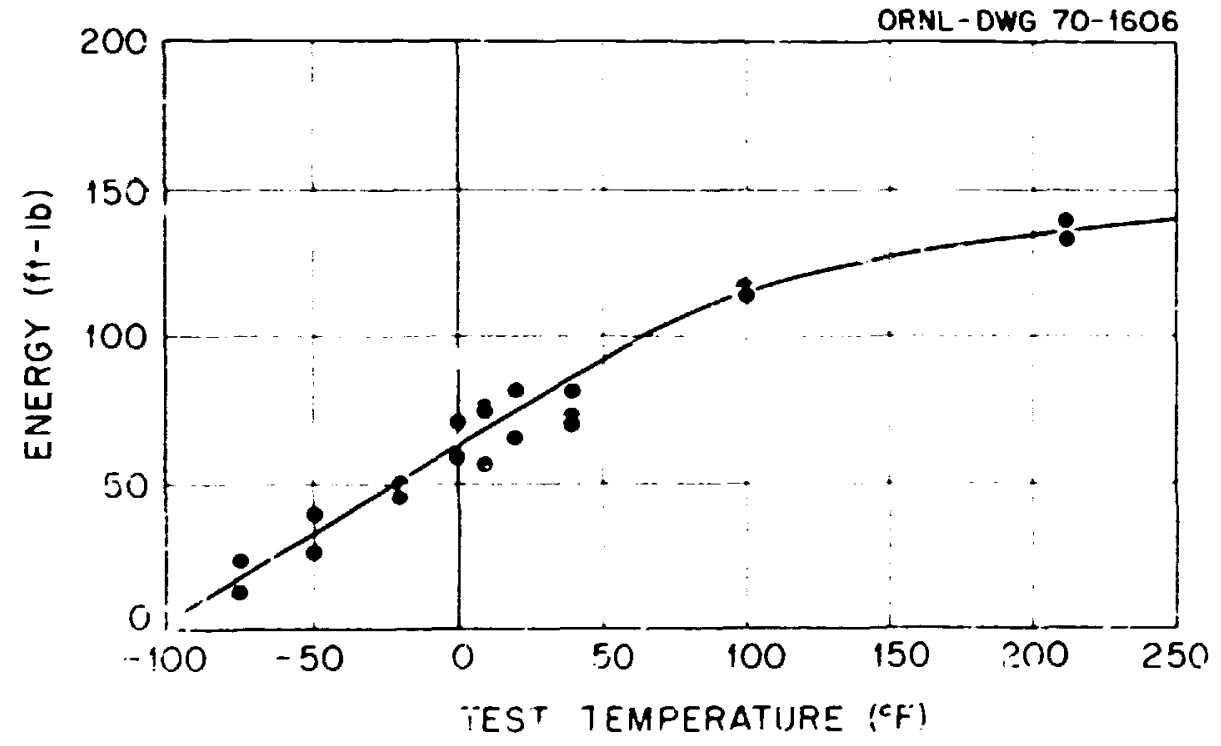

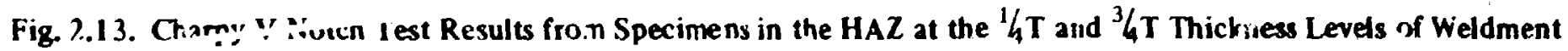
5ZAA. 


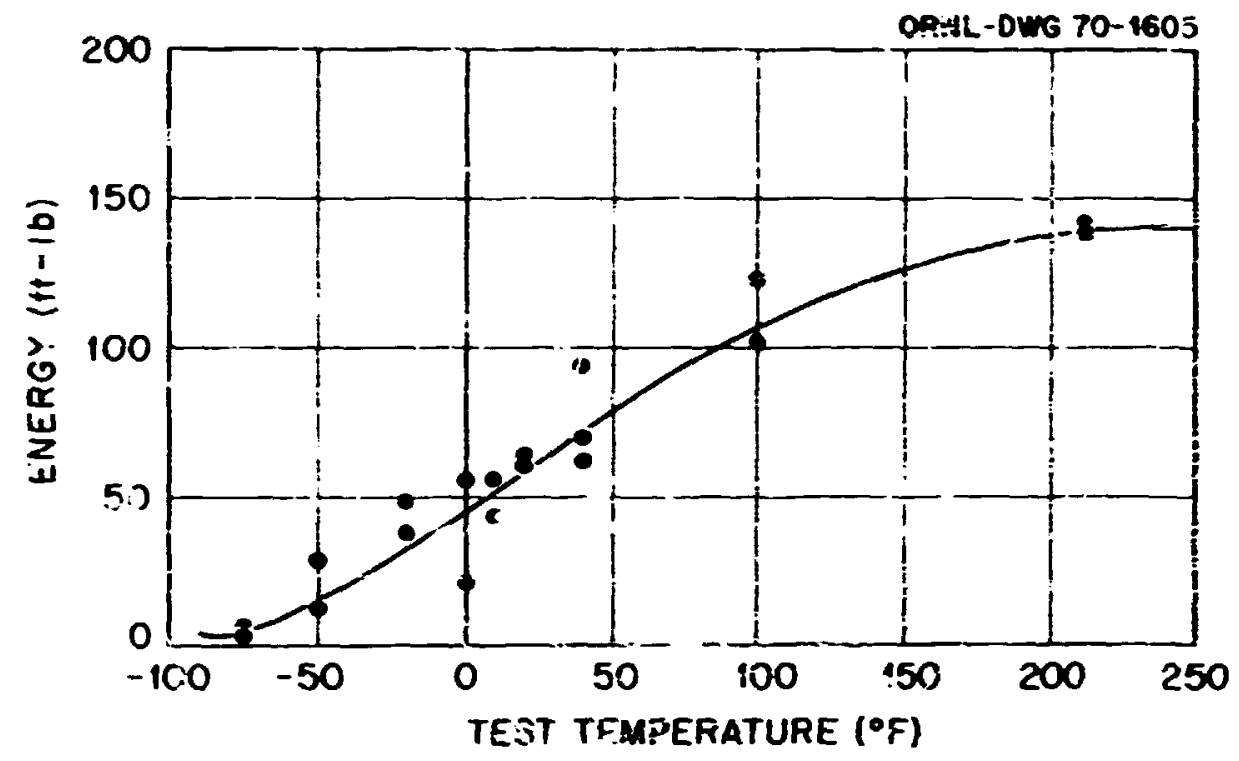

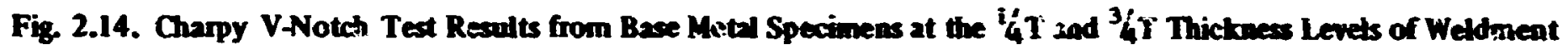
52A.

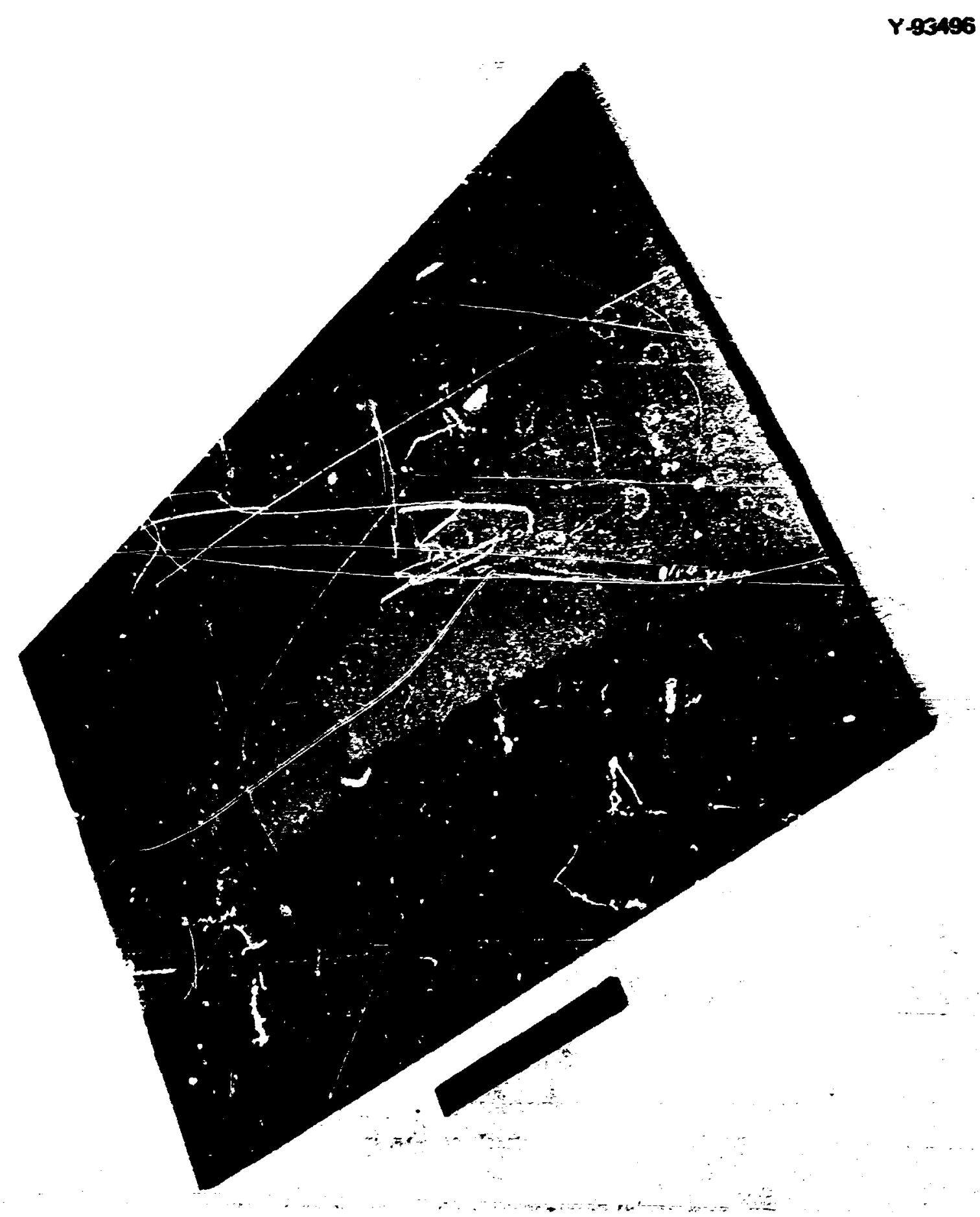

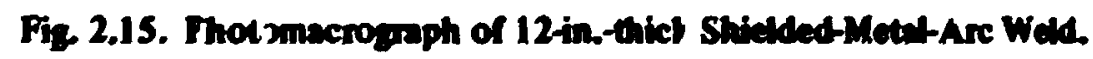


Phate section Oll was cut in half along the 14-in. dimension and joined at the two as-quenched edges. The weld joint preparations, which were of the double-J groove design, were prepared by machining. Prio: to fitup each was subjected to magnetic marticle inspection and found to be acceptable. The joint configuration and basic welding parameters are shown in Fig. 2.16. The more important steps in the welding procedure, heginning after fitup, are as follows:

1. Preheat to :boui $250^{\circ} \mathrm{F}$, and hold until postweld heal treatment (PWHT).

2. Welding in the fiat position, apply cbout $1 \frac{1}{2}$ in. of filler metal in the deep-groove side.

3. Invert the weldment, anis grind the root side to solid metal.

4. Inspect the ground surf 1 ce with magnetic particies.

5. Complete welding on the shallow-groove side.

6. Reinvart the weldment, and complete welding on the deep-groove side.

7. Grind itoth weld crowns flush with base plate, and inspect with magnetic particles.

8. Apoly interstage stress relief by heating to $1100 \pm 50^{\circ} \mathrm{F}$, and hold for $3 \mathrm{hr}$. Heating and cooling above $600^{\circ} \mathrm{F}$ not to exceed $100^{\circ} \mathrm{F} / \mathrm{hr}$.

9. Radiograph.

ELECTRODE SIZE AND TYPE FI-UX TYPE AND SIZE CURRENT AND POLARITY ARC VOLTAGE

TRAVEL SPEED in./min
ROOT

ORNL-DWG 69-3434R

REMAINDER

t/4-in., E-8018, C-3

325 TO 375 DC-SP

25
LINDE $1092,65-200$

$650 \mathrm{AC}$

34

13

WELDING POSITION: FLAT

PREHEAT: $250^{\circ} \mathrm{F}$, HELD UNTIL PWHT

INTERPASS : $500^{\circ} \mathrm{F}$

PWHT : VARIED FROM WELDMENT TO WELDMENT

INTERMEDIATE PWHT: $1100^{\circ} \pm 25^{\circ} \mathrm{F}$, HELD $15 \mathrm{~min}$

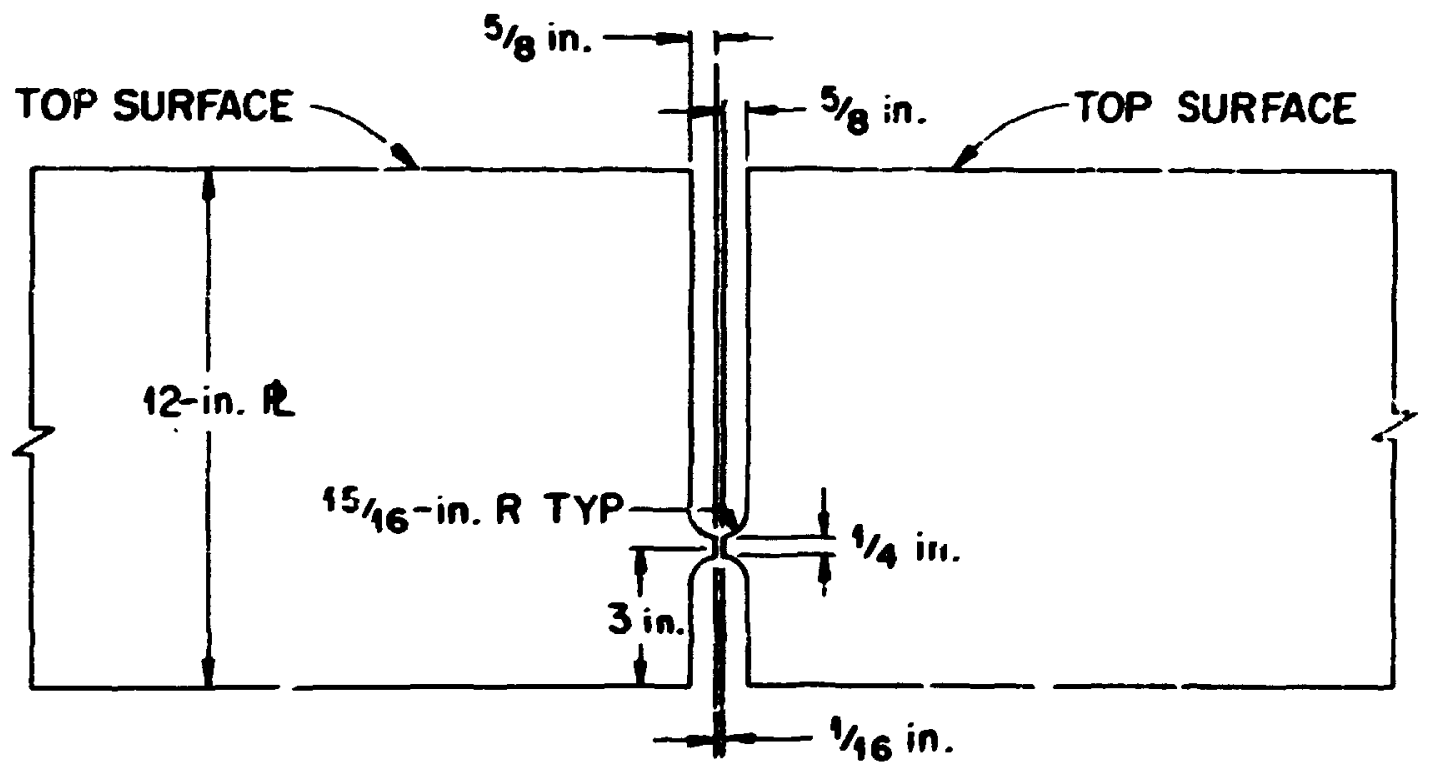

Fiz. 2.16. Joist Propention for the Submerped-Ase Wolds. 
10. At this stage any necessary repairs would be made; however, none was necessary.

11. Apply final stress relief by heating to $1150 \pm 2^{-n} \mathrm{~F}$, and hold for $37 \mathrm{hr}$. Heating and cooling ahove $600^{\circ} \mathrm{F}$ not to exceed $100^{\circ} \mathrm{F} / \mathrm{hr}$.

Note: 1 he weldrant in which phate section $01 \mathrm{~J}$ was joired to $01 \mathrm{~B}$ received an interstage stress relief if 15 min and final stress relief of $40 \mathrm{hr}$; the weld joining the two halves of $01 \mathrm{~N}$ received an interstage streas i-lief of $15 \mathrm{~min}$ and final stress relief of $15 \mathrm{hr}$. The weld joining the two halves of 01 A received a $2 \mathrm{hr}$ interstage stress relief and a $40 \mathrm{hr}$ final stress relief.

A completed weldment is shown in Fig. 2.17. This weldment is resting on a second member that has been prepared for welding. The heavy bracing on the lower member may be seen. By close observation, areas on the top surface of the completed weldment may be seen where the bracing has been removed and ground flush. Rinoff tabs are also z: parent on the completed weldment.

\section{H.4 Mechnical Testing of Submexged-Are Weldment 51}

The weldment fabricated from plate section 01L was designated HSST weldment 51. This weldment was subsequentily dirided into aro smonts, as shown in Fig. 2.18. The segment labsied 51B was assigned

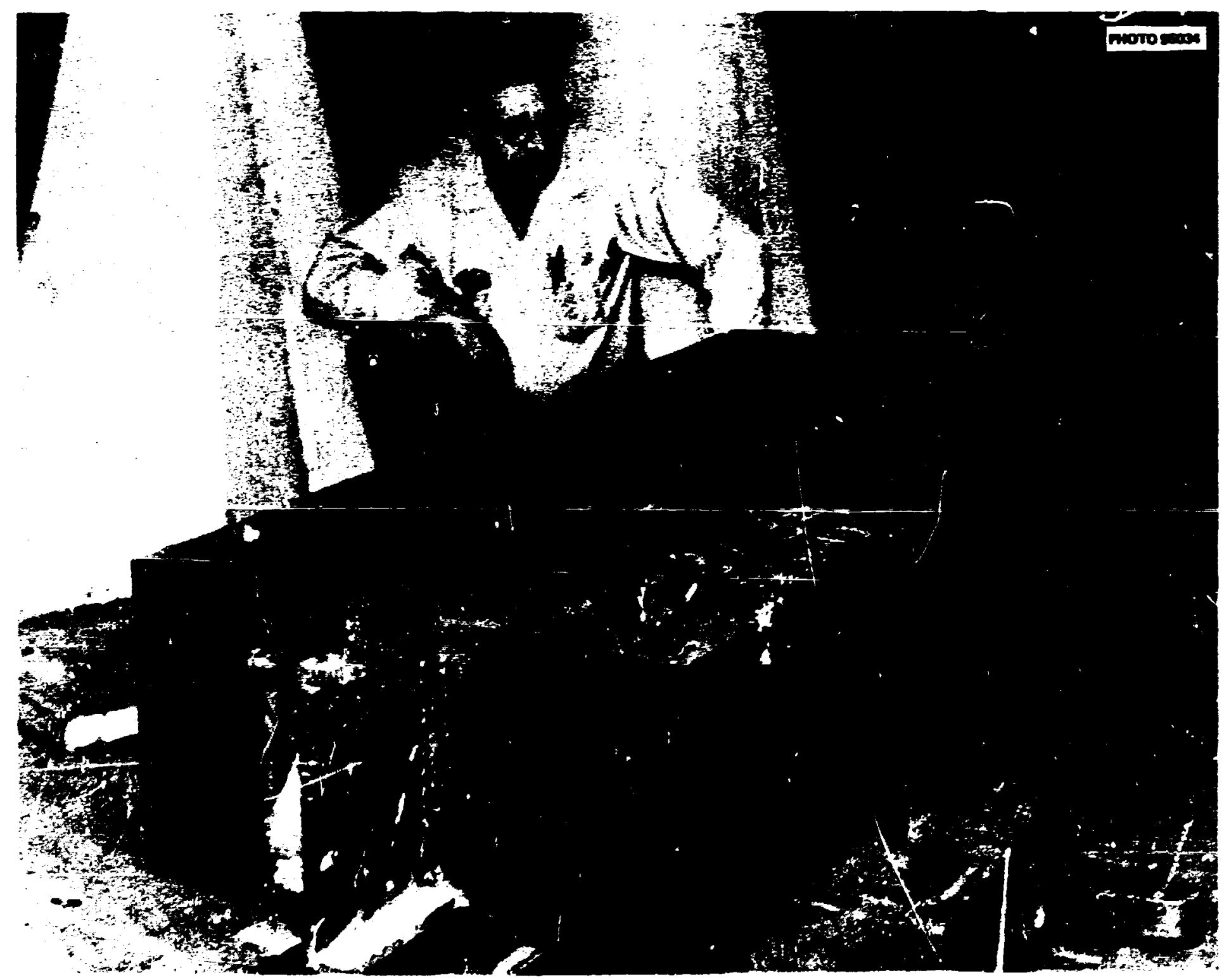

Piz 2.17. Completed Submerged-Ane Welderent. 
ORNL-DWG 70-11149

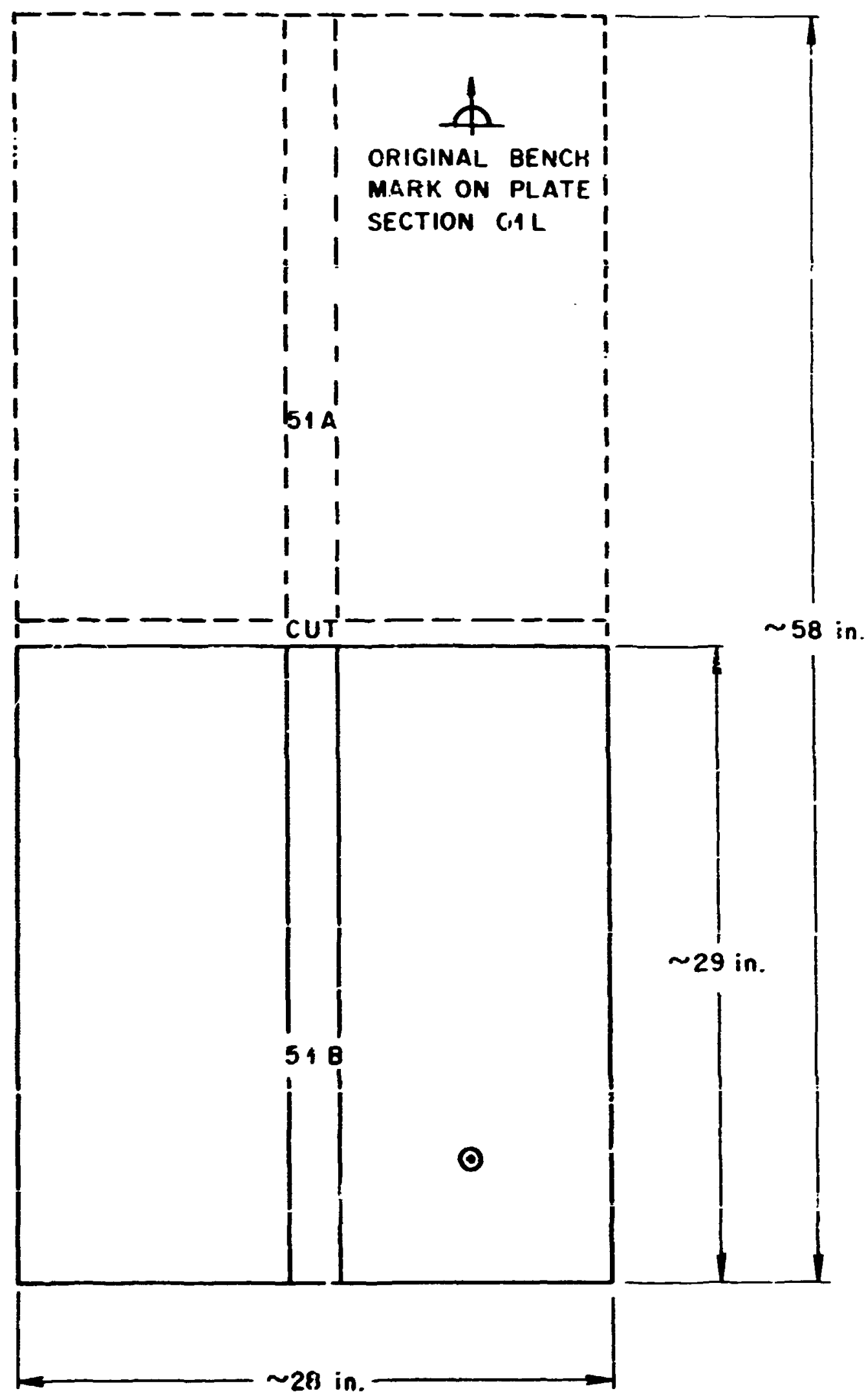

Fr. 2.18. Cutting Fin for Weldmeat 51. 
to D. A. Canonico, of the ORNL Metals and Ceramics Division, for characterization studies. The remainder of Part H.4 briefly surmmarizes the work performed by him thus far.

A photomacrograph of a cross section of the weldment, shown in Fig 2.19, delineates ine large number (some 200) of weld beads necessary to fabricate the weldment.

The filler, base, and weld metal compositions are listed in Table 2.7. It will be noted from Fig. 2.16 that the root of the weld is situated very near the $3 / 4 \mathrm{~T}$ level. In the table the variation in weld metal composition (from surface to surface) is listed, except for the $\xi_{4} \Upsilon$ location. Because of dilution, the chemical composition in this region is not typical, therefore not included.

If the region in the vicinity of the weld root is ignored, the carbon content of the weld metal through the thickness (surface to surface) averages $0.14 \pm 0.02 \%$. The carbon content of the weld metal at $3 / 4 \mathrm{~T}$ is about $0.25 \%$, a vaiue very near that of the base material. The compositionai ieveis of the other eiements listed in Table 2.7 are within acceptable ranges, regardless of location.

The range of chemical variation throughort the i2-in. thickness of the weld metal is impressively low, except for copper. However, the concern in this case is not related to mechanical properties, but rather to the possibility of radiation sensitivity.

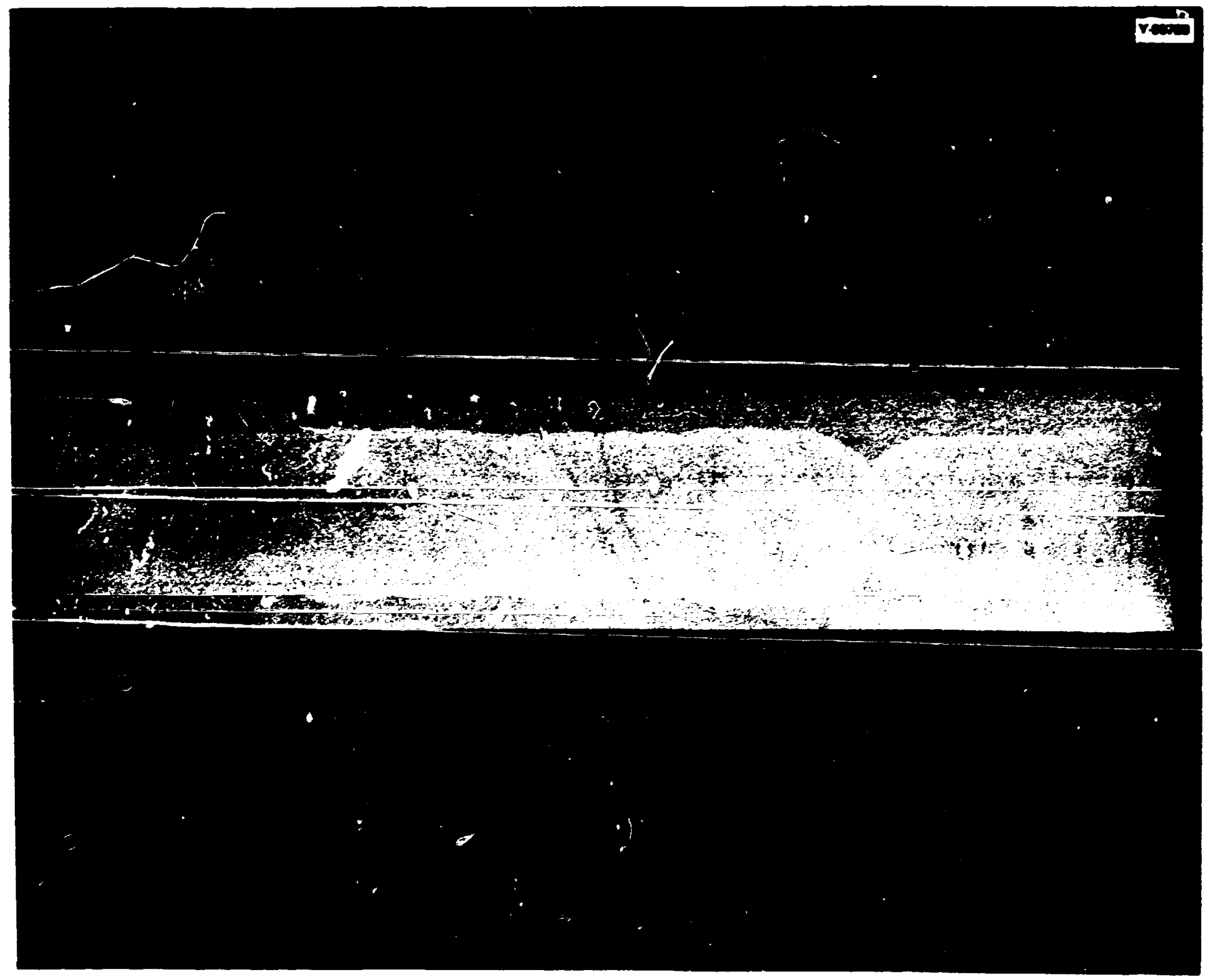

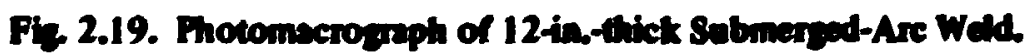




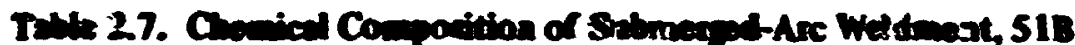

\begin{tabular}{|c|c|c|c|c|c|c|c|c|}
\hline \multirow{2}{*}{$\begin{array}{l}\text { Weldineat } \\
\text { Componest }\end{array}$} & \multicolumn{8}{|c|}{ Memical Composition (wt \%) } \\
\hline & $\mathbf{C}$ & $\mathbf{M a}$ & Mo & $\mathbf{N i}$ & $\mathbf{P}$ & $\mathbf{s}$ & Si & $\mathrm{Cu}$ \\
\hline Filex metal & 0.17 & 1.5 & $0.5 i$ & 0.75 & 0.014 & & 0.07 & 0.07 \\
\hline Base metal & 0.22 & 1.48 & 0.52 & 0.68 & 0.012 & 0.018 & 0.25 & 0.14 \\
\hline Wold metal & $0.12-0.16$ & $1.23-1.38$ & $0.39-0.53$ & $0.72-0.76$ & $0.013-0.017$ & $0.008-0.015$ & $0.05-0.15$ & $0.15-0.33$ \\
\hline
\end{tabular}

Check andysis (by plate fabricator).

Trenores smples from 3/4T bocation.

A number of Charpy $V$-notch $\left(C_{v}\right)$ specimens were removed from various locations in weldment $51 B$. Transverse $C_{V}$ properties were determined for the $1 / 4 T$ level and perpendicular $C_{v}$ properties for the $1 / 2 T$ level. Further, a througth-thickness investigation of the siffect of location on the weld metal notch toughness was undertaicen to determine if sirnilar $C_{\mathbf{v}}$ weld metal properties exist, regardless of location.

Results of the transverse $C_{V}$ sts are listed in Fig. 2.20 as well as a sketch describing the specimen location and orientation. The weld siomed a $30-\mathrm{ft}+\mathrm{b} \mathrm{C}_{\mathrm{v}}$ temperature of $-60^{\circ} \mathrm{F}$, whereas the $30-\mathrm{ft}-\mathrm{b}$ iemperature of the base piate $(1 / 4 T)$ was about $+10^{\circ} \mathrm{F}$. Both base plaie and weid metal exhibited $\mathrm{C}_{\mathrm{v}}$ sheif energies of $115 \mathrm{it}+\mathrm{b}$. The fracture appearance transition temperature (FATT) for $50 \%$ ductile fracture occurred at about $+10^{\circ} \mathrm{F}$.

The data for through-thickness studies are given in Fig. 2.21. Sach lest was condusted at the 30-it-1b $C_{v}$ temperature for the $1 / 4 \mathrm{~T}$ level, $-60^{\circ} \mathrm{F}$. This figure shows a considerable number of data points below

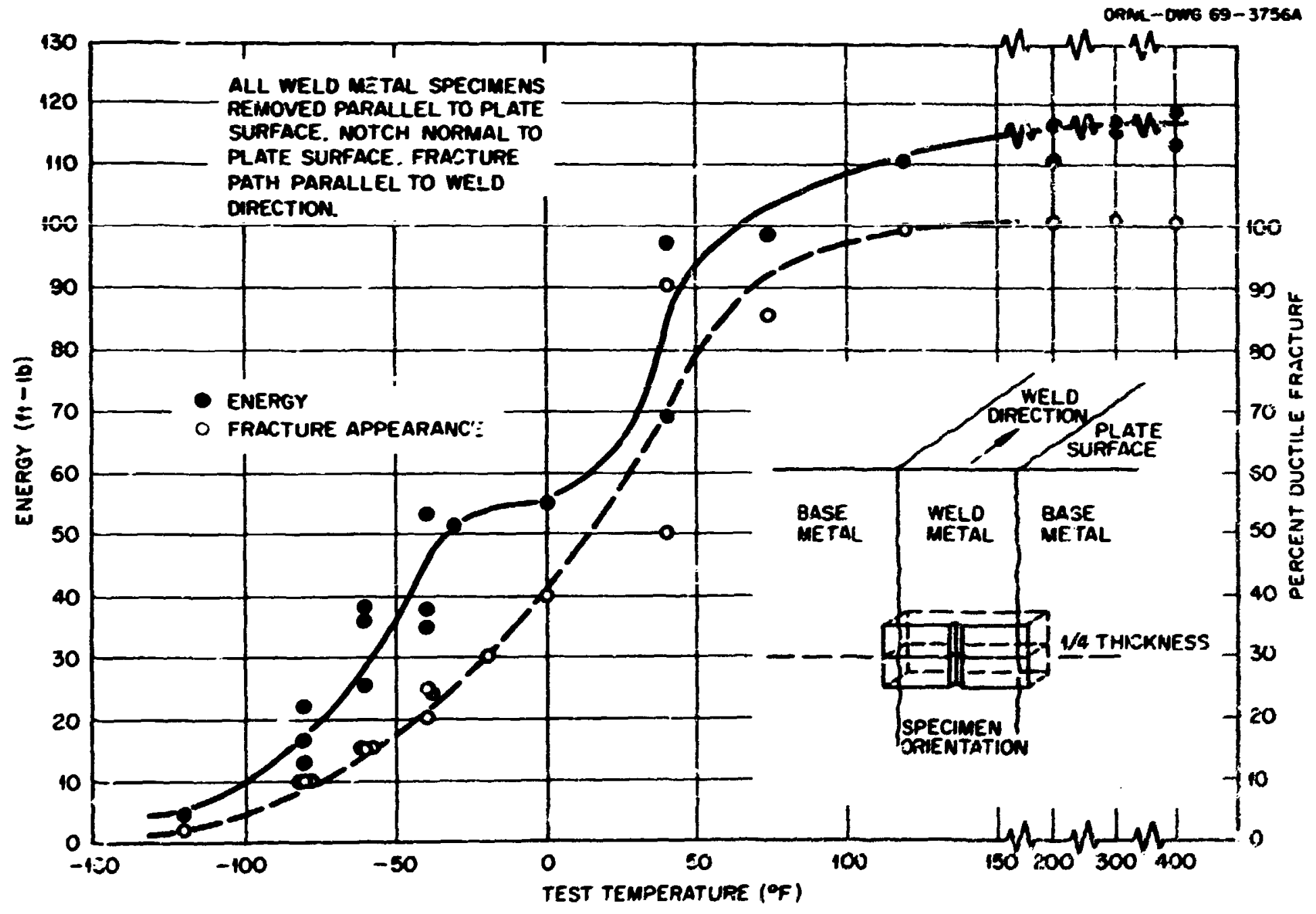

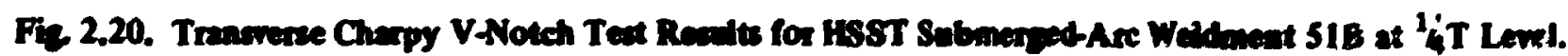




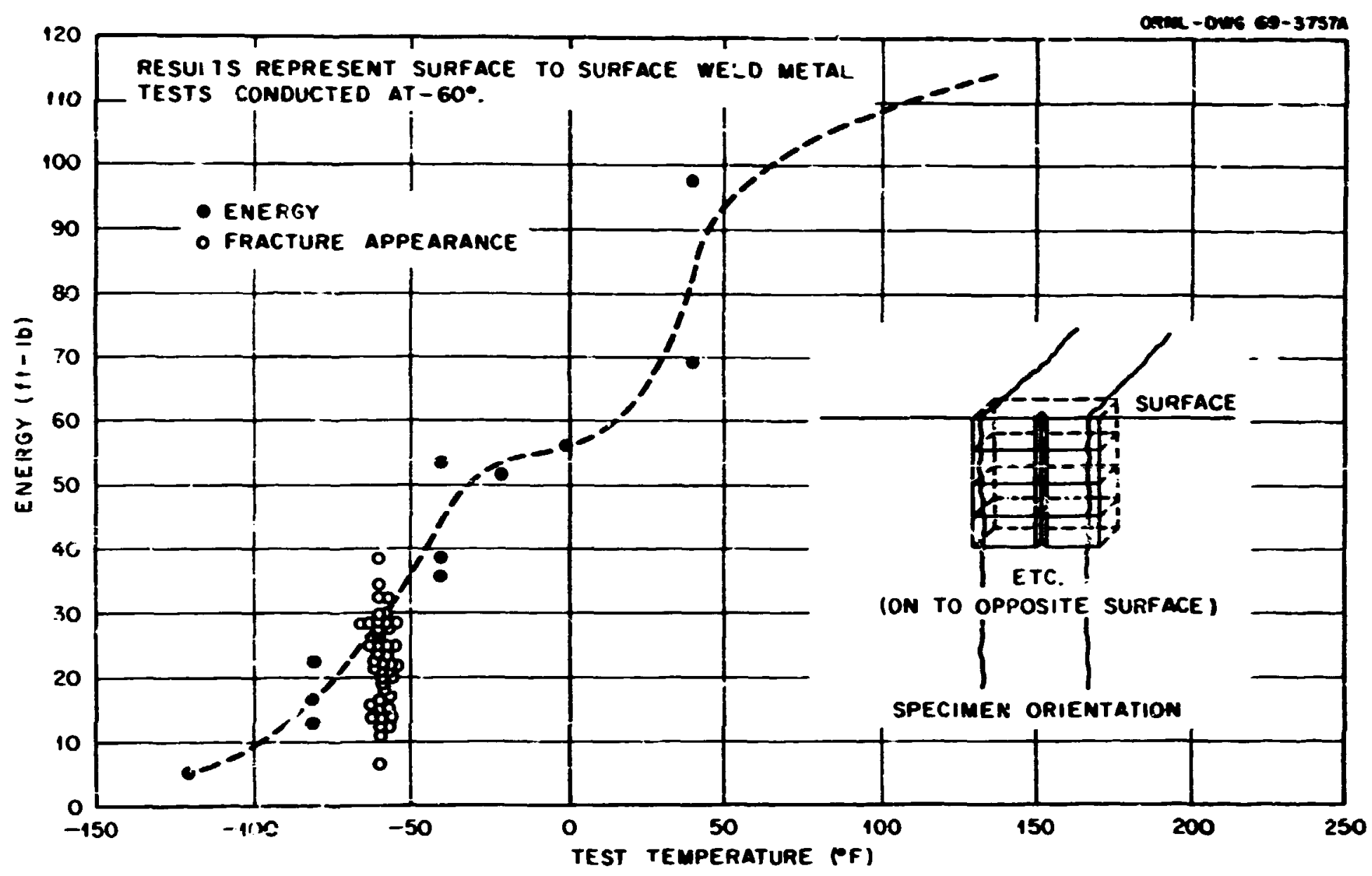

Fig 2.21. Throwathickwes Chapy V-Notch Test Resilts for HSST Sebmenged-Arc Weddmeat S1B.

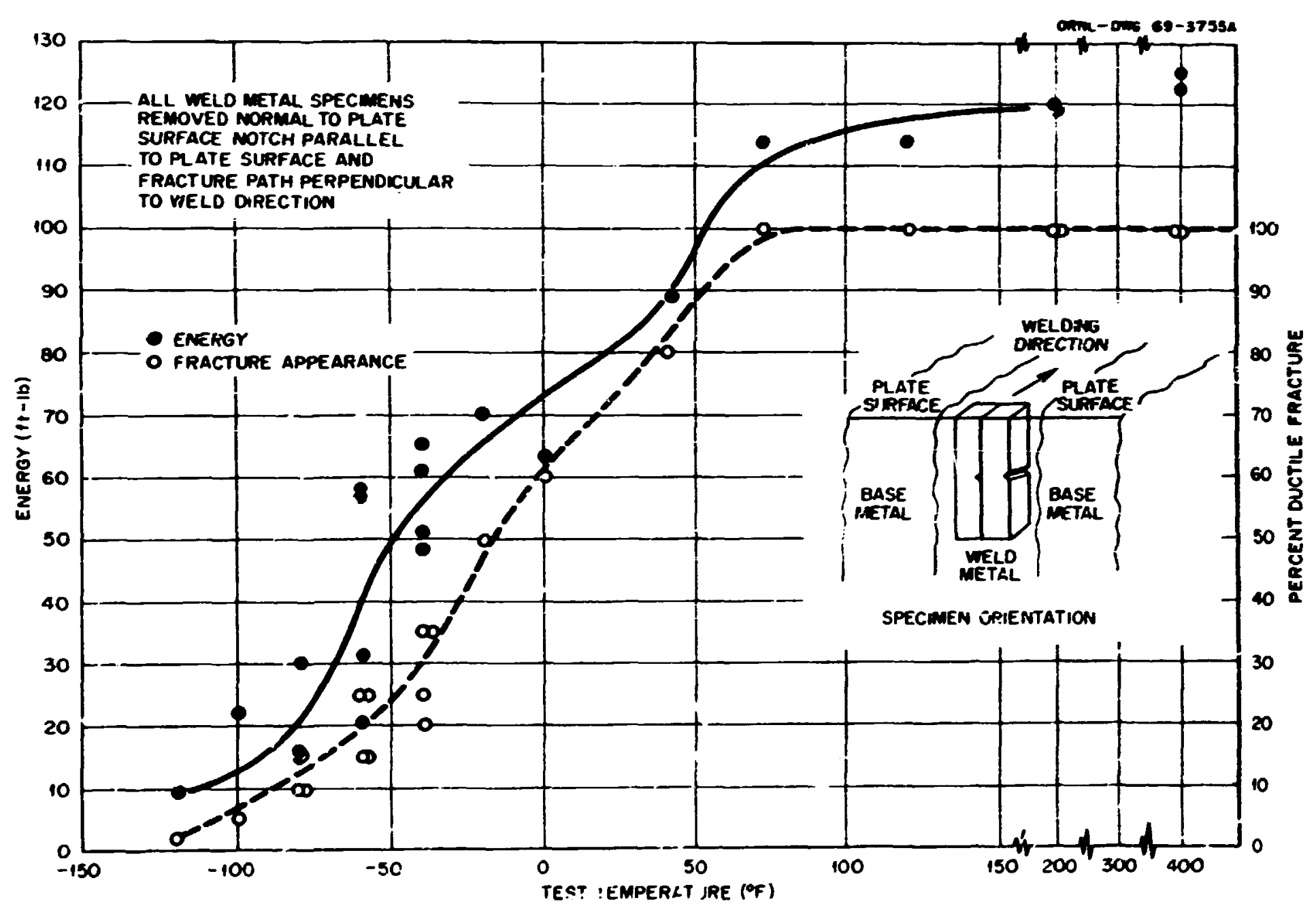

Fig. 2.22. Petpendicular Chapy V-Notch Text Results for HSST Submerged-Arc Weldment SIB. 
the 30-fitb fred; however, this spread in energy level is not uncommon, even for a consiterably more homogeneous base metal.

Dals related to perpendicular $C_{v}$ tests are shown in $F_{i z} 2.22$, as well as specimen location and orientation. The results are similar to these obtained at the $1 / 4 \mathrm{~T}$ level, except for the difference in the FATT. In this case the $50 \%$ ductile fracture occurred at about $-20^{\circ} \mathrm{F}$. The $30-\mathrm{ft}-\mathrm{bb} \mathrm{C}_{\mathrm{v}}$ temperature for the perpendicular specimens is about $-70^{\circ} \mathrm{F}$, whereas it was near $-60^{\circ} \mathrm{F}$ for the transversi $C_{V}$ tests.

Broken Charpy specimens were used for determining the chemical analysis of the weld metal. The initial results, if the $3 / 4$ T specimens are igrored. indicate that the chemical corroposition of the weld metal is similar, regardless of the specimen location or orientation. It is also apparent that the $30-\mathrm{ft} t \mathrm{i} \mathrm{C}_{\mathbf{v}}$ weld metal transition temperature is superios to that of the base metal without any sacrifice in shelf energy.

\section{HIST XRY OF A 61/4-in.-thick ELECTROSLAG WELDMIENT DONATED TO THE ESST PROGRAM}

Bids for the fabrication of an electroslag weldrnent were solicited at the same time a request was submitted for bids on the submerged-arc and shielded-metal-arc weldments. The stipulations were the same; vendors were requested to fabricate the mildments precisely as they would for those currently being used in class A nuclear vessels. Unfortunately, at this time no major vendor was using the electroslag welding process to fabricate nuclear vessels. Consequently, no propesals were received, and it appeared for some time that HSST studies of weldments would be confined to the submerget-arc and shielded-metal-arc varieties.

The Pressure Vesel Research Committee's (PVRC) Industry Cooperative Program on Materials Properties and Inspection of Heavy Section Steels donated a segment of a $61 / 4$-in.-thick weldment to the HSST program for evaluation. In addition to other information, the following data pertaining to the weldment were transmitted by L. J. Chockie, Secretary of the Task Group on Materials Properties, to the HSST program:

PVRC identification number: 315 (General Electric)

Material description: electroslag-welded longitudinal seam

Base metal specification: SA 302, grade B (Code Case 1339)

Base metal thickness: $6 \% / 4$ in.

Approximately one-half of an electroslag welded test plate was ordered in addition to that required for the manufacturing of surveillance test specimens. Oit the remaining section, 4 in. were scrapped from the end, the next or adjoining 10 in. were sent to General Electric, and 32 in. were donated to the HSST Program....

The $61 / 4$-in.thick plate was welded and heat treated by Babcock and Wilcox along with the vessel and is assumed to be typical of the vessel material.

A sketch accompanying the information listed above is shown in Fig. 2.23. As noted, the weld was made between two sections of $6^{1 / 4}$-in.-thick plates, identified as slab 1 and slab 2 . No information was submitted to indicate the manufacturer of the steel. Ladie and check chemical analyses of the respective slabs and filler wire are as follows: 

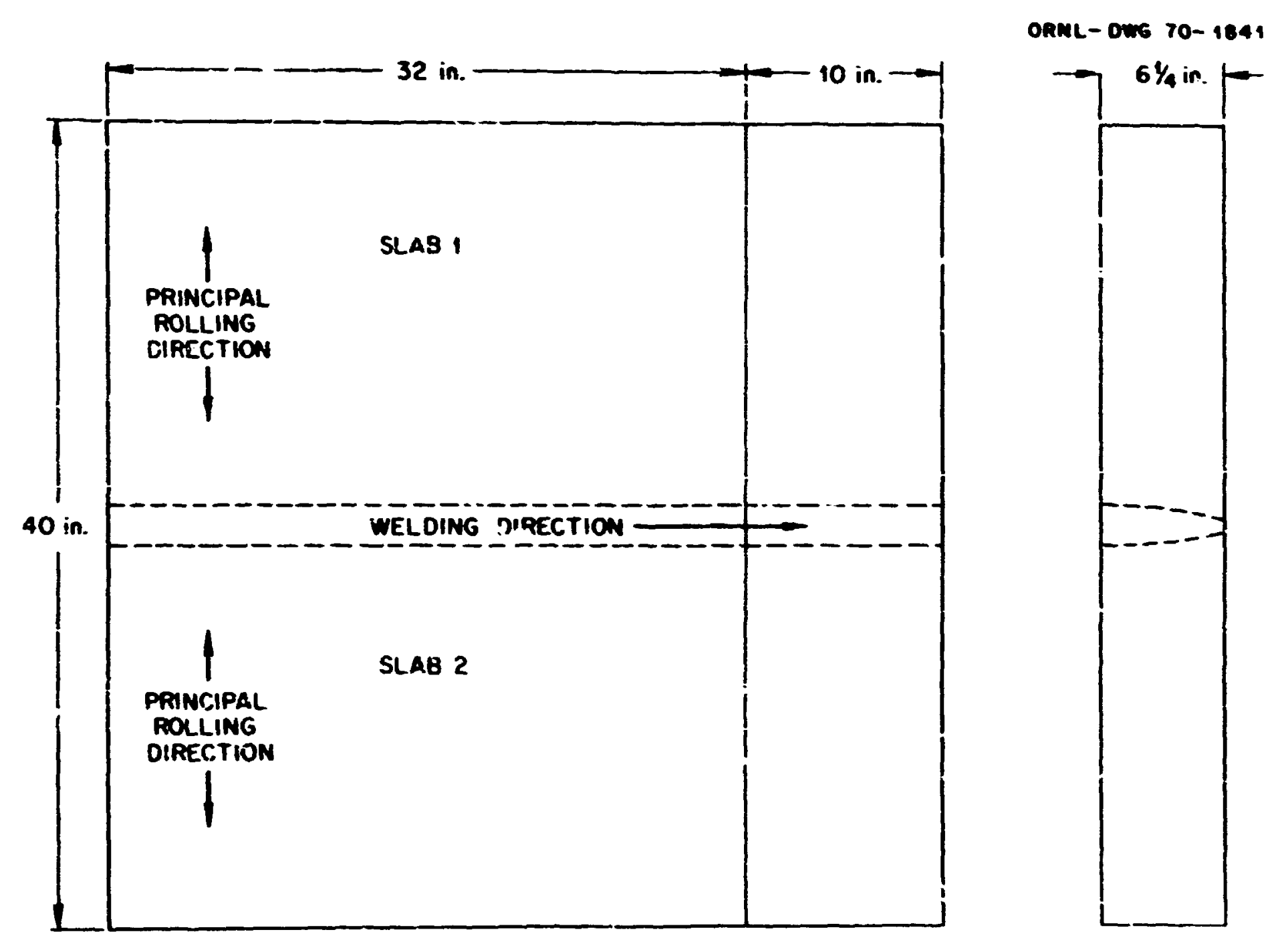

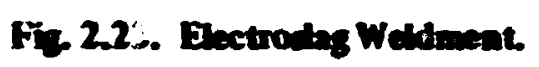

The plates were welded in the vertical position using $1 / 3$-in.-diam filler wire and Linde flux 124 . The welding c urrent was $500 \mathrm{~A}$, and the voltage range was 48 to $52 \mathrm{~V}$.

The completed test plate was heat treated as follows:

$1700 \pm 25^{\circ} \mathrm{F}$ for $1 \mathrm{hr} / \mathrm{in}$. and water quenched

$1 \leqslant 25 \pm 25^{\circ} \mathrm{F}$ for $1 \mathrm{hr} / \mathrm{in}$. and water quenched

Stress relieved at $1200 \pm 25^{\circ} \mathrm{F}$ for $1 \mathrm{hr} / \mathrm{in}$. and water quenched

Stress relievec' at $1125 \pm 25^{\circ} \mathrm{F}$ for $30 \mathrm{hr}$ and furnace cooled

A photomacrograph of the weld zone, including adjacent base metal is shown in Fig. 2.24. A zricrohardness traverse across the weld zone near the plate surface is plotted in Fig. 2.25. The base metal appears to be somewhat harder, 225 (DPH) av as opposed to 190 (DPH) av fo: the weld metal. A similar traverse taken at the $1 / 2 T$ level showed essentiafly' no difference in hardness between the base and weld nistal, both av 197 (DPH).

Specimens for Charpy V-notch $\left(C_{V}\right)$ testing were cut from a 12-in.-wide section of the weldment (with the weld in the center) slabbed from the $1 / 4 T$ level parallel to the plate surface. Four sets of $C_{\text {. }}$ specimens were machined from the locatione shown in Fig. 2.26. The resulis of these tests are plotted in Fig. 2.27 and summarized as follows: 
Notch Location

Base metal

Weld midplance

HA 7/base interface

$1 / 16$ inch into base from $\mathrm{HAZ}$ $30-\mathrm{ft}-1 \mathrm{~b}$

Tempereture

(F)

33

46

27

9

40-fttb
Temperature
(F)

4?

50

39

21
Upper Stedr

ft+b

170

88

137

$>220$

Tempreratures for both 30 - and 40 it $1 \mathrm{~b}$ values are given, since tirere is some question as to which corresponds to the NDT transition temperature as measured by drcp rieigh! testing.

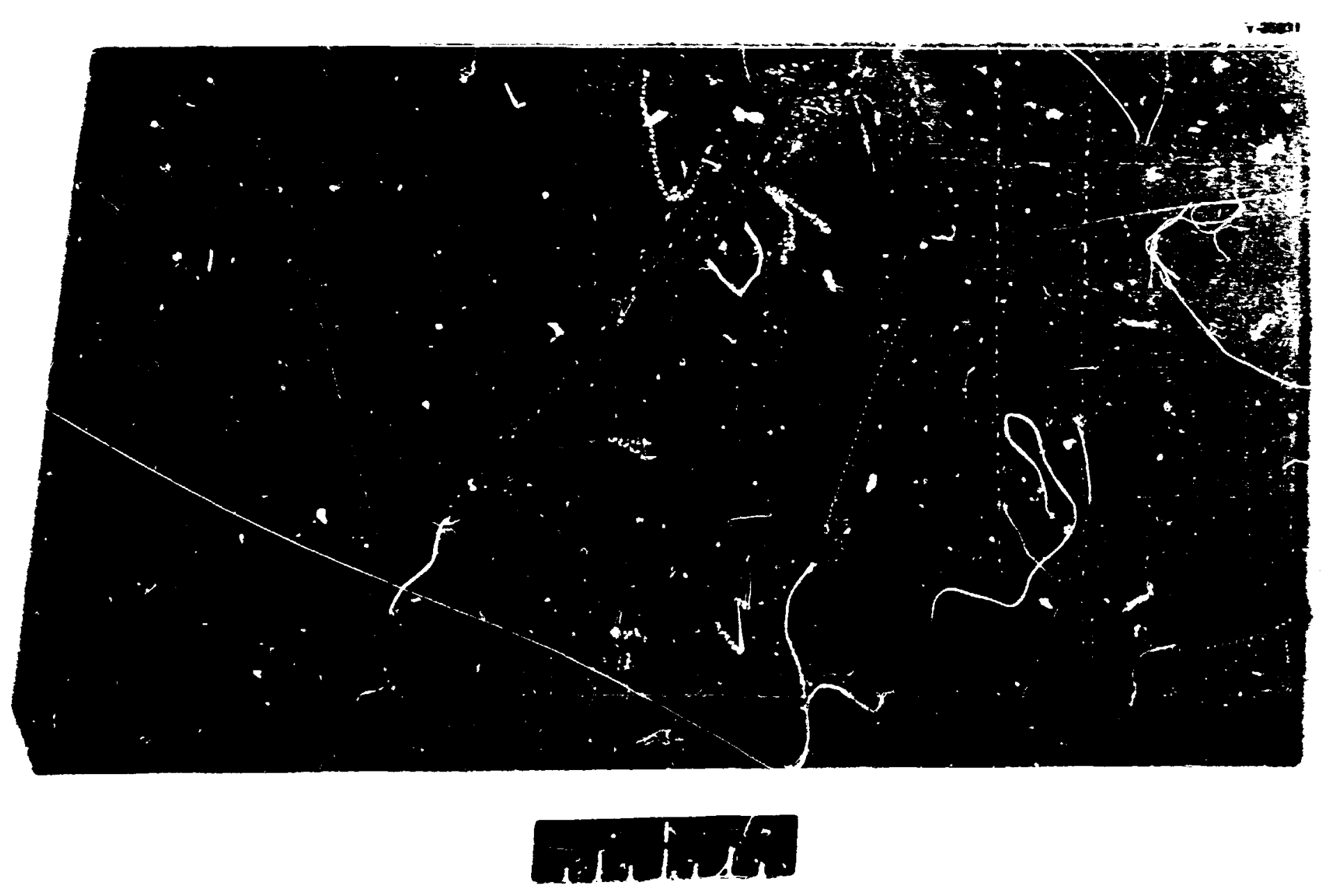

Fig 2.24. Photomacrograph ơ o' 4 -in.-thick Electroslag Weldment. 


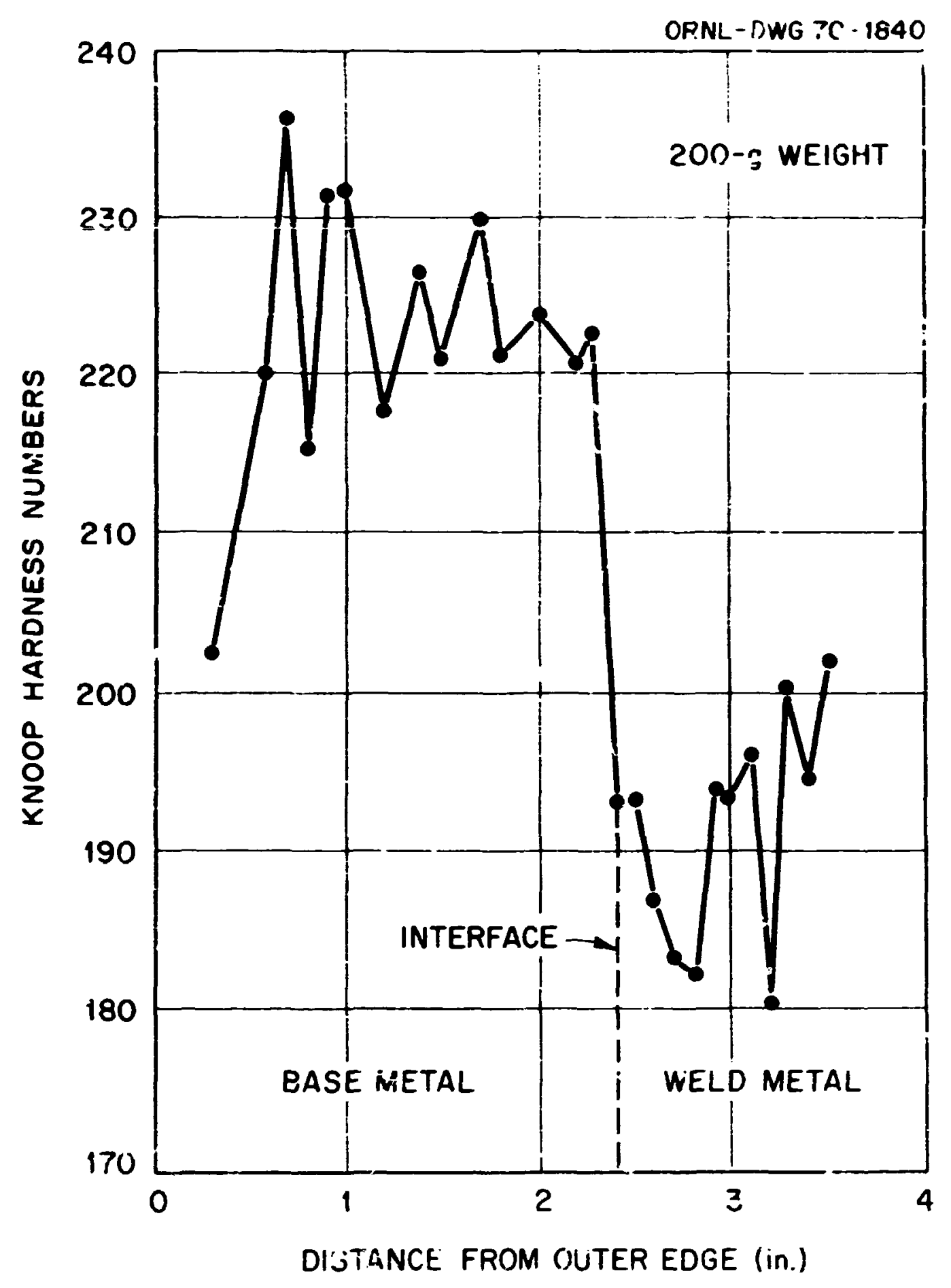

Fig. 2.25. Hicrohardness Traverse Acrose Weld Zone nesi Flate Surface of Flectrodag Weldment. 


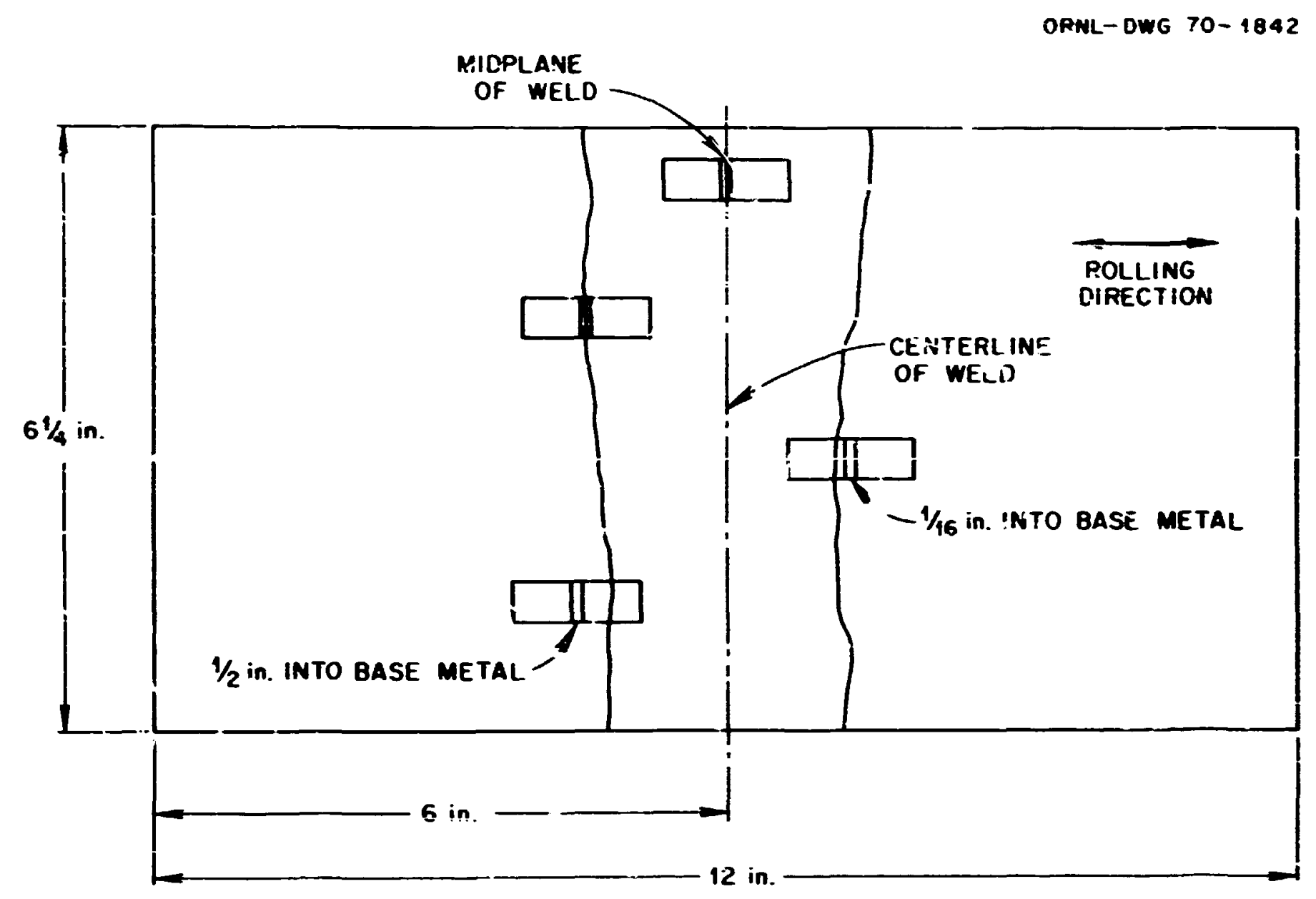

Fie. 2.26. Location of Chopy V-Nourh Specinese from Eloctrody Weldmeat.

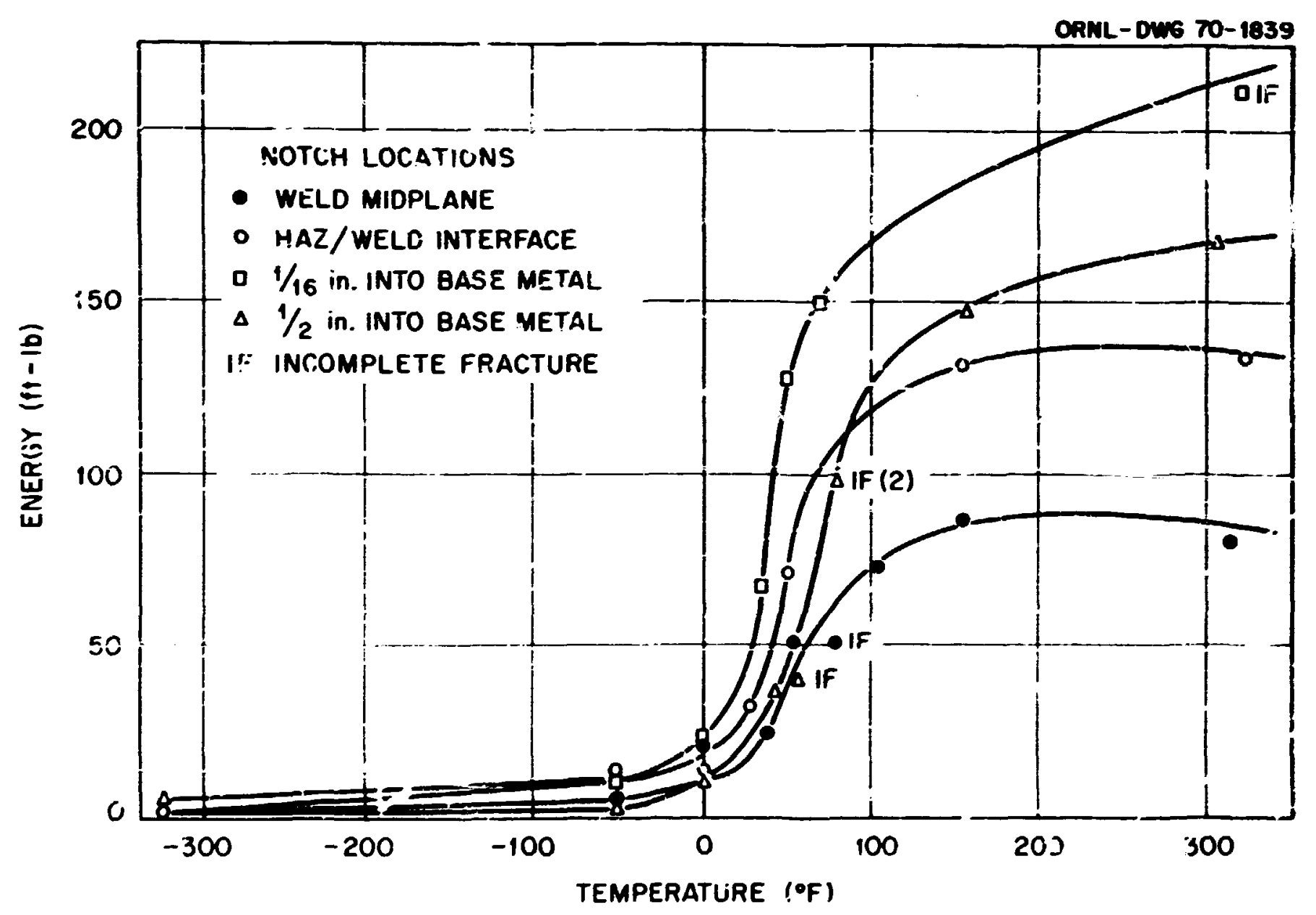

Fig. 2.2\% Charpy V-Notch Teat Recults from Electroestag Wo divent. 


\section{T.ABRICATION / ND WELDING OF A 6-in.thich ASTM A-533 (,RADE B, CLASS 1 PLATE}

\section{J. FABRICATION OF 6-in-thick ASTM A-533 GRADE B, CLASS 1 PLATE}

The HSST staff decided that additional thick-section weldments would be needed to proceed with the ilanned investigative program. To provide material for additional weldments, a 6-in.-thick ASTM A-533 grade B, class 1 plate was purchased frum Lukens Steel Company. The order specified that the steel (1) metet the requirements of Sect. III of the ASME Code for class A nuclear vessels, (2) be vacuum degassed, (3) be uinde by the basic eiectric furnace process, and (4) have concentrations of phosphonas and sulfur as low as posible, but restricted to 0.012 and $0.015 \% \mathrm{max}$, respectively, in the ladle and check ar alyses.

The 6-in.thict phate, Lukens heat $\mathrm{C62004}$, in ingot form measured $70 \times 30$ in. ar.d weighed $33,300 \mathrm{lb}$. The ingot was stabbed to 3 thickness of 18 in. and sow coled. On completion if cooling, the slab was conditim ground, reheated, rolled to 6 -in. thickness, and sand ccoled. The lon itudinal/transverse rolling ratio wa 2.36:1 The resulis of the balle analysis are:

\begin{tabular}{|c|c|c|c|c|c|c|c|c|}
\hline c & $\mathbf{M}$ & $\mathbf{P}$ & $\mathbf{s}$ & 0 & xis & $a$ & 100 & $\mathbf{S i}$ \\
\hline 21 & 1.38 & $0.01 p$ & 0.014 & 0.12 & 0.48 & 0.17 & 0.47 & 0.18 \\
\hline
\end{tabular}

Heat treatment of the plate consister in (1) austenitizing at $1675 \pm 25^{\circ} \mathrm{F}$ for a Shr hold period, followed by water quenchisis; (2) reaustenitizing at $1575 \pm 25^{\circ} \mathrm{F}$ for a 6 hr hold period, followed by water quenching; (3) tempering at 122 ' $\pm 25^{\circ} \mathrm{F}$ for a $6 \mathrm{hr}$ hold period, followed by water quenching; and (4) stress relieving at $1125 \pm 25^{\circ} \mathrm{F}$ for a thr ioid perioi, followed by air cooling. Each hear treatment was performed in a ratural-garited car-isotton furmace. All quenching was done with the plate in the flat position.

Furnace thermocouples only were used :o record the heat treat da:a; consequently, cooling-rate daia are not avaibale. The location of the plate in the rumace for the first austenitizing heat treatment is shown in Fig. 3.1; the spread in furnace thermcsouple readings for this heat treatment is shown in Fig. 3.2. For reaustenitizing, the plate occupied essentidly the same position in the furnace as for the first austen:tizing heat treatment. The spread in thermocouple readings for the reaustenitizing heat treatment is shown in Fig. 33. During the tempering heat treatment, the plate was oriented as shown in Fig. 3.4; spread in furnace thermocouple readings is shown in Fis. 3.5 .

The plate was then preheated, and material for test specimens was cut from the oserroll armas. The test speciunens were machined and program stress relieved to simulate the stress relieving heat treatment applied to tie phate. Reaults of the cherrical check analysis and mechanical tes ing are as follows:

$$
\begin{array}{cccccccccc} 
& C & M & P & \text { S } & \text { C. } & \text { Ni } & C_{\text {. }} & \text { Si } & \text { Si } \\
\text { Chock } & 0.24 & 1.36 & 0.010 & 0.015 & 0.11 & 0.40 & 0.17 & 0.46 & 0.19
\end{array}
$$

\begin{tabular}{|c|c|c|c|c|c|}
\hline $\begin{array}{l}\text { Specimea } \\
\text { Location }\end{array}$ & $\begin{array}{l}\text { Spaciecen } \\
\text { Orientation }\end{array}$ & $\begin{array}{l}0.240 \text { Offer } \\
\text { Vield Strength (ke) }\end{array}$ & $\begin{array}{l}\text { Uhimate } \\
\text { Temeile } \\
\text { Streagth } \\
\text { (lai) }\end{array}$ & $\begin{array}{c}\text { Elmpation } \\
\text { (\%) }\end{array}$ & $\begin{array}{l}\text { Reduction } \\
\text { in Afres. } \\
\text { (\%) }\end{array}$ \\
\hline Top $1 / 4 T$ & $\mathbf{T}$ & 67.4 & 87.2 & 24 & 63.1 \\
\hline $\operatorname{Top} 1 / 4 T$ & $\mathbf{I}$ & 68.0 & 87.6 & 24 & 66.4 \\
\hline
\end{tabular}




\section{Curpy Impect Teat Datn}

\begin{tabular}{|c|c|c|c|c|c|}
\hline $\begin{array}{l}\text { Specimea } \\
\text { Location }\end{array}$ & $\begin{array}{l}\text { Speciminen } \\
\text { Orientation }\end{array}$ & $\begin{array}{l}\text { Spectimen } \\
\text { Tempesture (F) }\end{array}$ & $f(t)$ & $\begin{array}{c}\text { Lateral } \\
\text { Expansion (mis) }\end{array}$ & $\begin{array}{l}\text { Pracent } \\
\text { Streat }\end{array}$ \\
\hline Botiom 1 $k T$ & $\mathbf{L}$ & RT & $84-95-95$ & 70-78-78 & 85 \\
\hline Bottum $1 / 4 T$ & $\mathbf{L}$ & $+i 0$ & $59-57-58$ & $54-51-52$ & 45 \\
\hline Bottom $1 / T$ & $\ell$ & -50 & $39-34-25$ & $35-33-25$ & 25 \\
\hline Bottom $1 / 4 \mathrm{~T}$ & $\mathbf{L}$ & -75 & i9-33-29 & $28-26-17$ & 10 \\
\hline Bottom $1 / 4 \mathrm{~T}$ & $T$ & RT & $79-60-51$ & $72-62-30$ & 80 \\
\hline Botton $1 / 4 \mathrm{~T}$ & $\mathbf{T}$ & +40 & $56-50-50$ & $.53-50-50$ & 60 \\
\hline Bottom $1 / 4 T$ & $\mathbf{T}$ & $: 10$ & $38-33-39$ & $46-36-48$ & 35 \\
\hline Bottom $1 / 4 T$ & $\mathbf{T}$ & -20 & $16.21-28$ & $19-2 j-29$ & 20 \\
\hline
\end{tabular}

ORML-DW6 70-2091

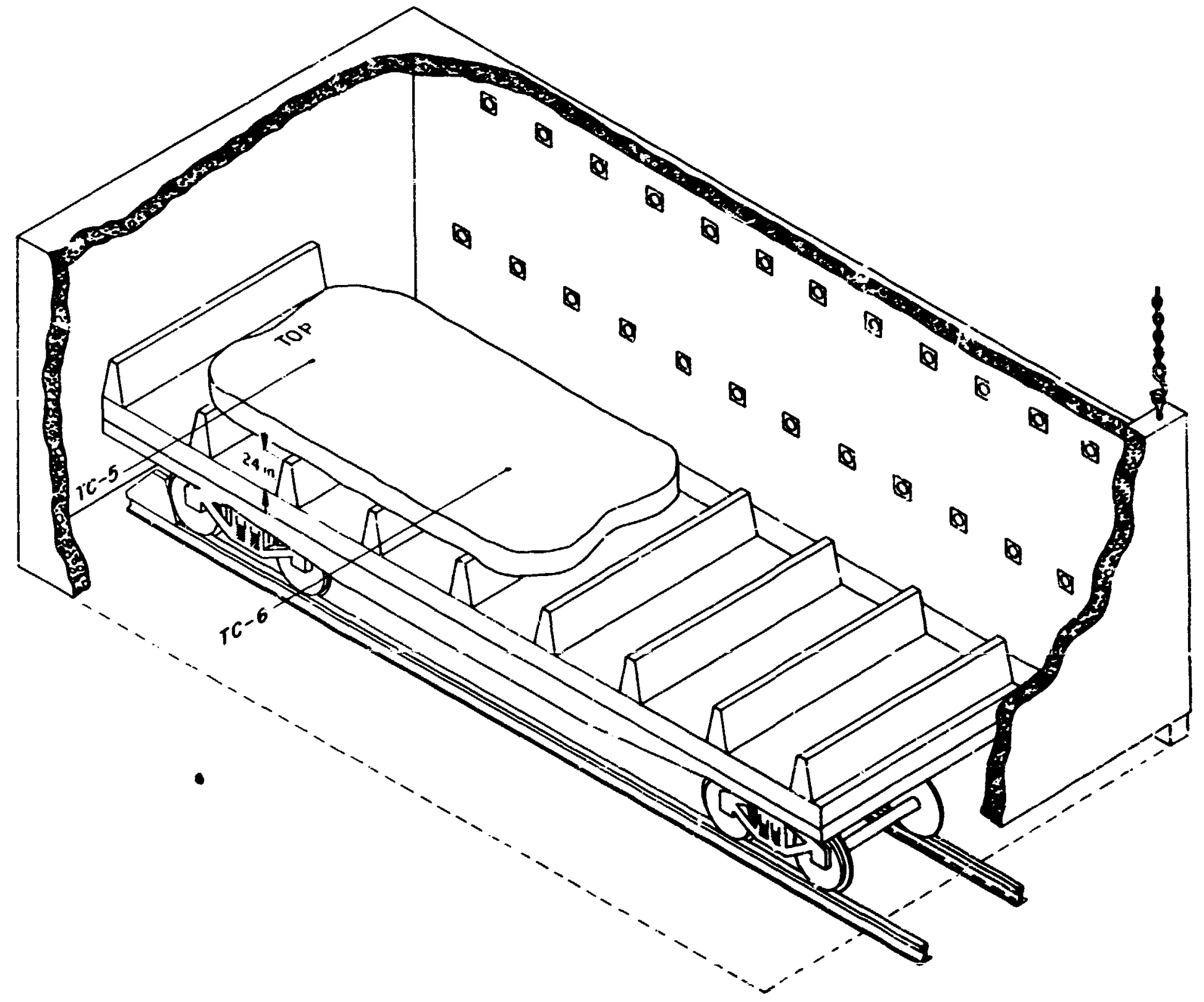

Fig. 3.1. Orientation of the 6-in.-thick Flate in the Furmce for the Austeniticing Heat Treatnent. 


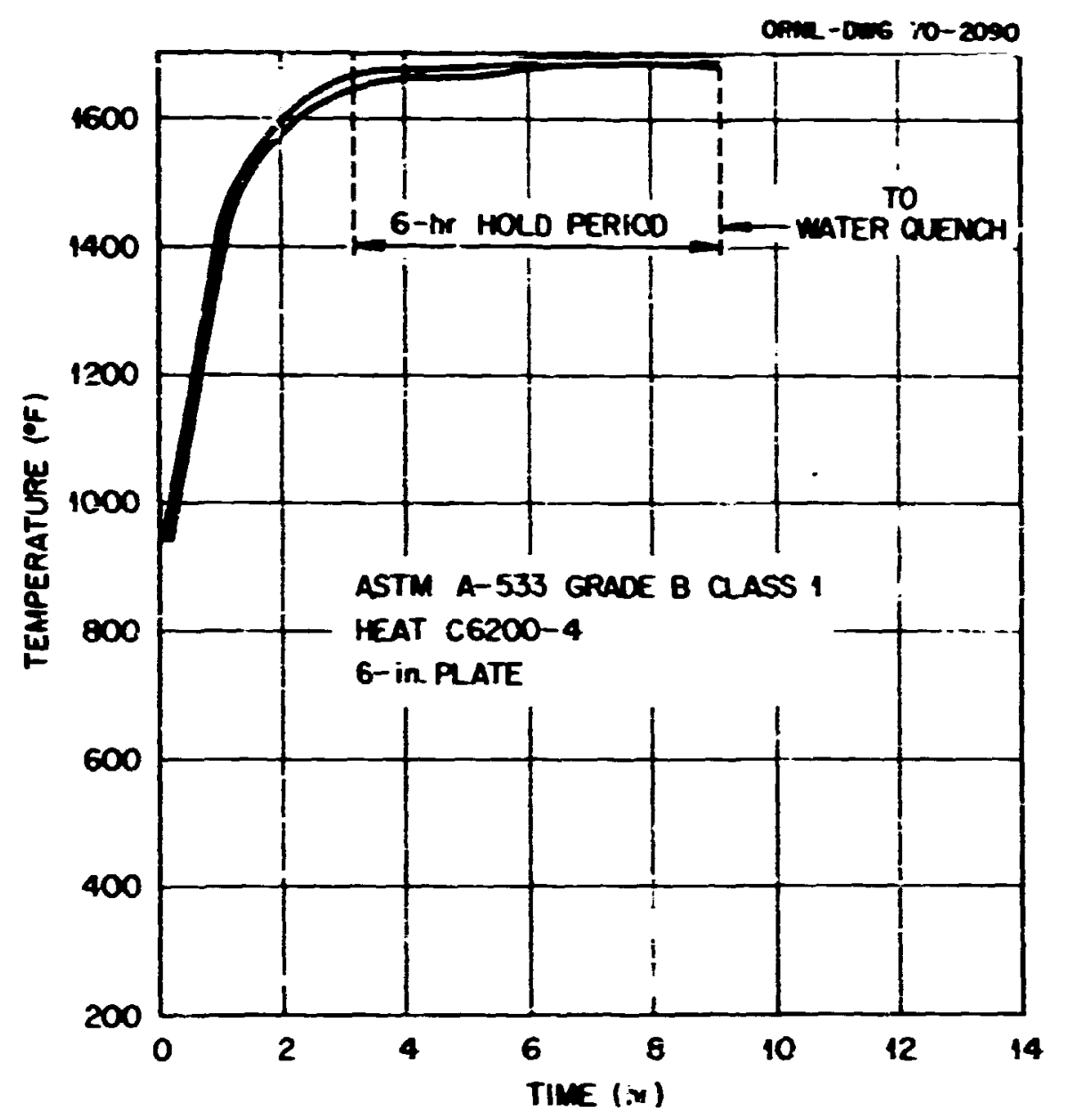

Fy 3.2. Spread in Themoconple Readies Dring Austeritiving of the 6-in-thick Phate

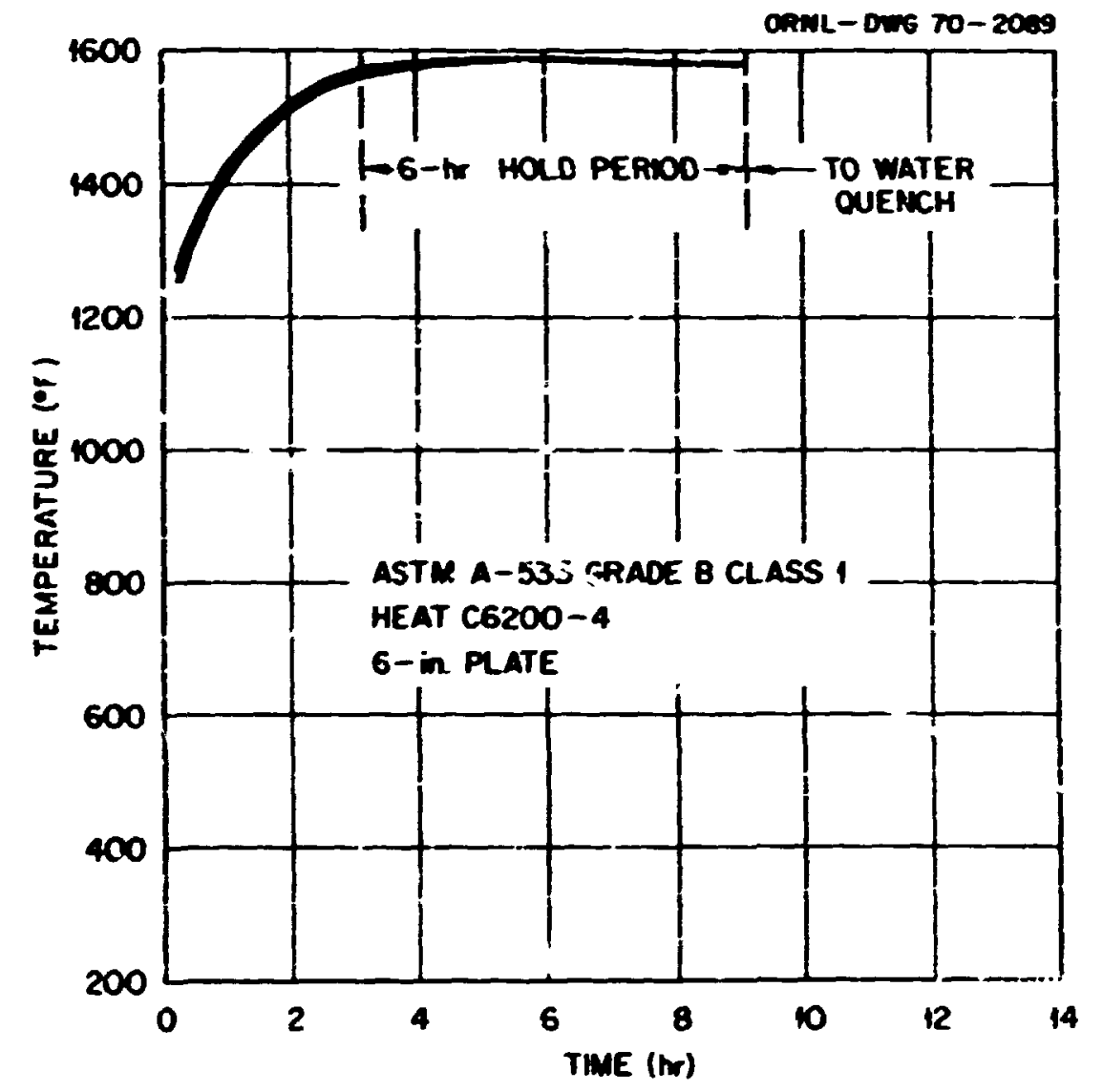

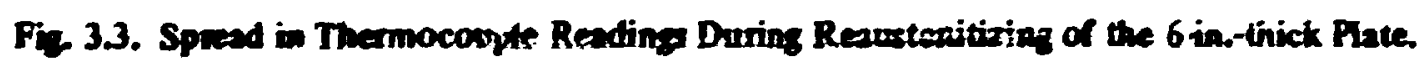




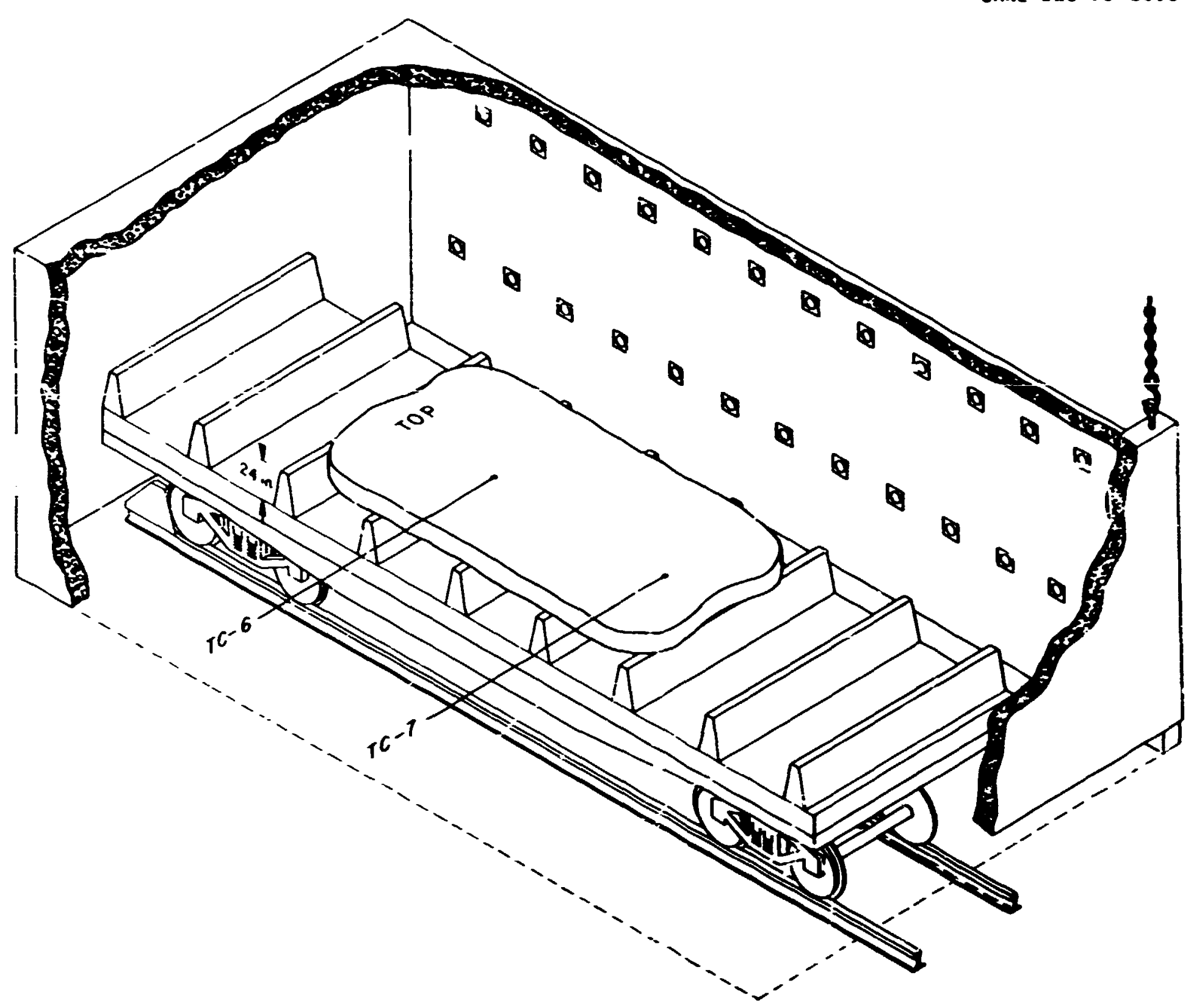

Fig. 3.4. Orientation of the 6-in-thick Fate in the Furmece for the Tempering Heat rrentment.

On completion of mechanical testing, the plate was preheated to about $500^{\circ} \mathrm{F}$, and a $96 \times 144 \mathrm{in}$. pattern was cut out. The plate pattern was then placed in the furnace as shown in Fig. 3.6 and strexs relieved for $1 \mathrm{hr}$. The stress-relief data for this heat treatment are plotted in Fig. 3.7.

The plate was hand ground to an approximate $250 \mathrm{mms}$ surface finish preparatory to ultrasonic inspection pe: paragraph N321.1 of Sect. III of the ASLE Code for Nixclear Vessels. This paragraph states

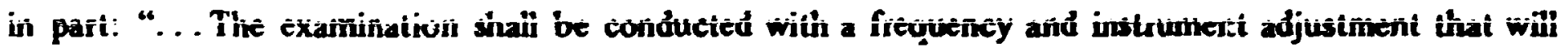
produce a minimim 50 to a maximum 75 per cent of full scale referenca back reflection from the opposite side of a sound area of a plate.....

“(a) Any area where one or more discontinuities proiuce a continuous total loss or back ieffection accompanied by continuous indications on the same plane that cannot be encompased within a circle whose diameter is $3 \mathrm{in}$. or $1 / 2$ of the plate thickness, whichever is greater, is unacceptable.

"(b) In addition two or more defects smaller than described in $4(a)$ shall be unacceptable unless separated by a minimim distance equal to the greatest diameter of the larger defect or unles they may be collectively encomprassed by the circle described in $\mathbf{4 ( a ) . "}$ 


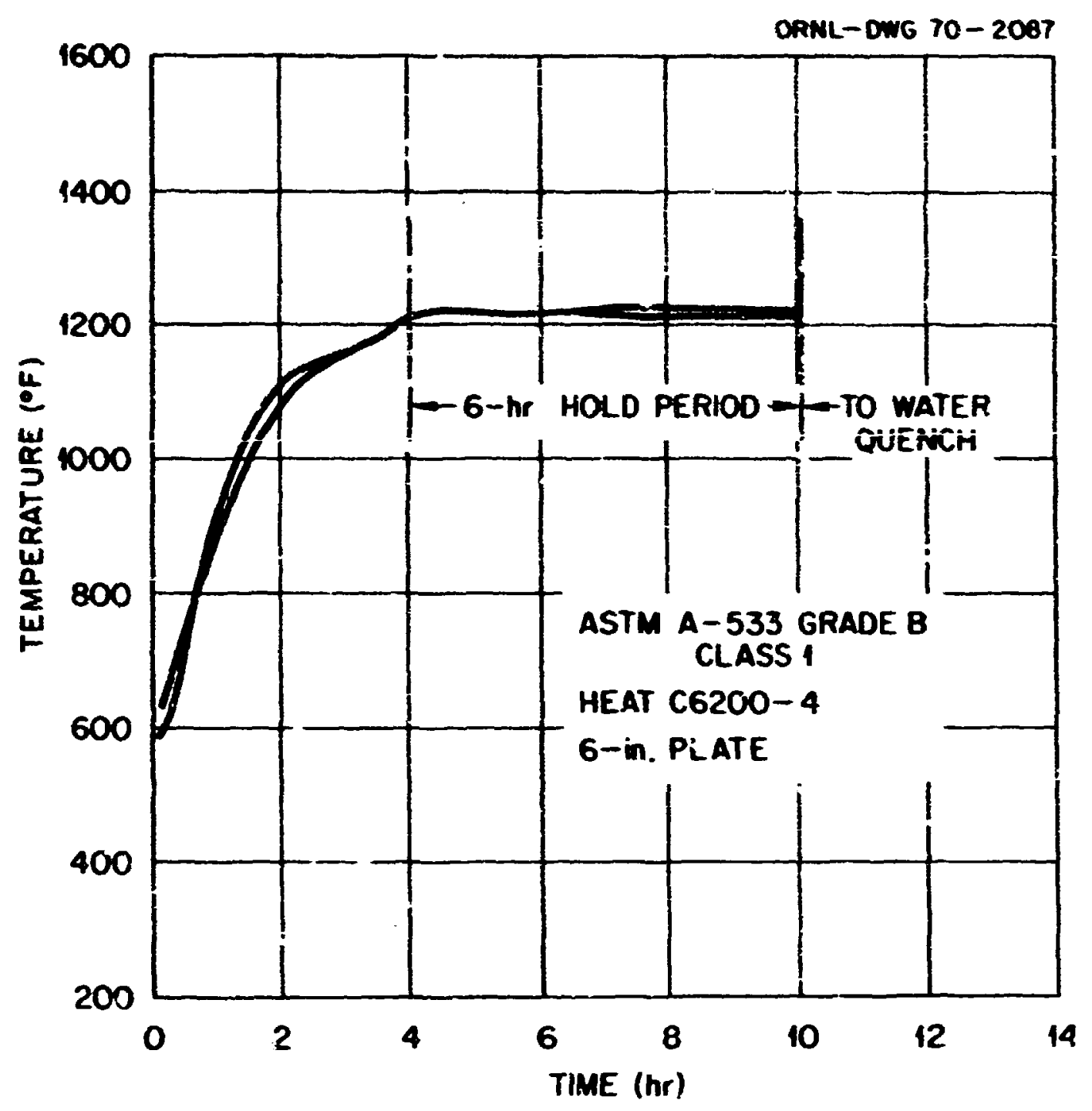

Fiz 3.5. Spread in Twermocomple Reading Duing Temperiag of the 6-in-thich Plate.

Utrasonic inspection of the 6-in.-thick plate was performed at Lukens' Coatesville, Pennsylvania, mill on August 12, 1969. A UM-721 reflectoscope with a $1^{1 / 3}$-in.-diam, 2.25.MHz quartz crystal and a watersoap solution couphant were used to inspect the plate. No indications of recordable magnitude were found. On completion of ultrasonic testing the plate was shipped to Combustion Engineering, Inc., of Chattanouga, Ten os ssee.

\section{K. FABRICATION OF WELDMENTS FROM THE 6-in-thick ASTM A-533 GRADE B, CLASS 1 PLATE}

The plate, even though it was to be cut into subsections and made into weldments, was assigned HSST plate number 11 for iemporary identification.

The plate was received by Combusrion Engineering in September. Shortly afterwards the cutting plan shown in Fig. 3.8 was scribed on the top surface (aurface to the top during rolling). Each plate section was stamped with the HSST bench mark and an alizmment mark. The coordinates of each of these points are established from the point of origin. By such a system, any point in the plate may be described in terms of Cartesian coordinates, with the origin at the top left corner on the top surface when the plate is oriented as 


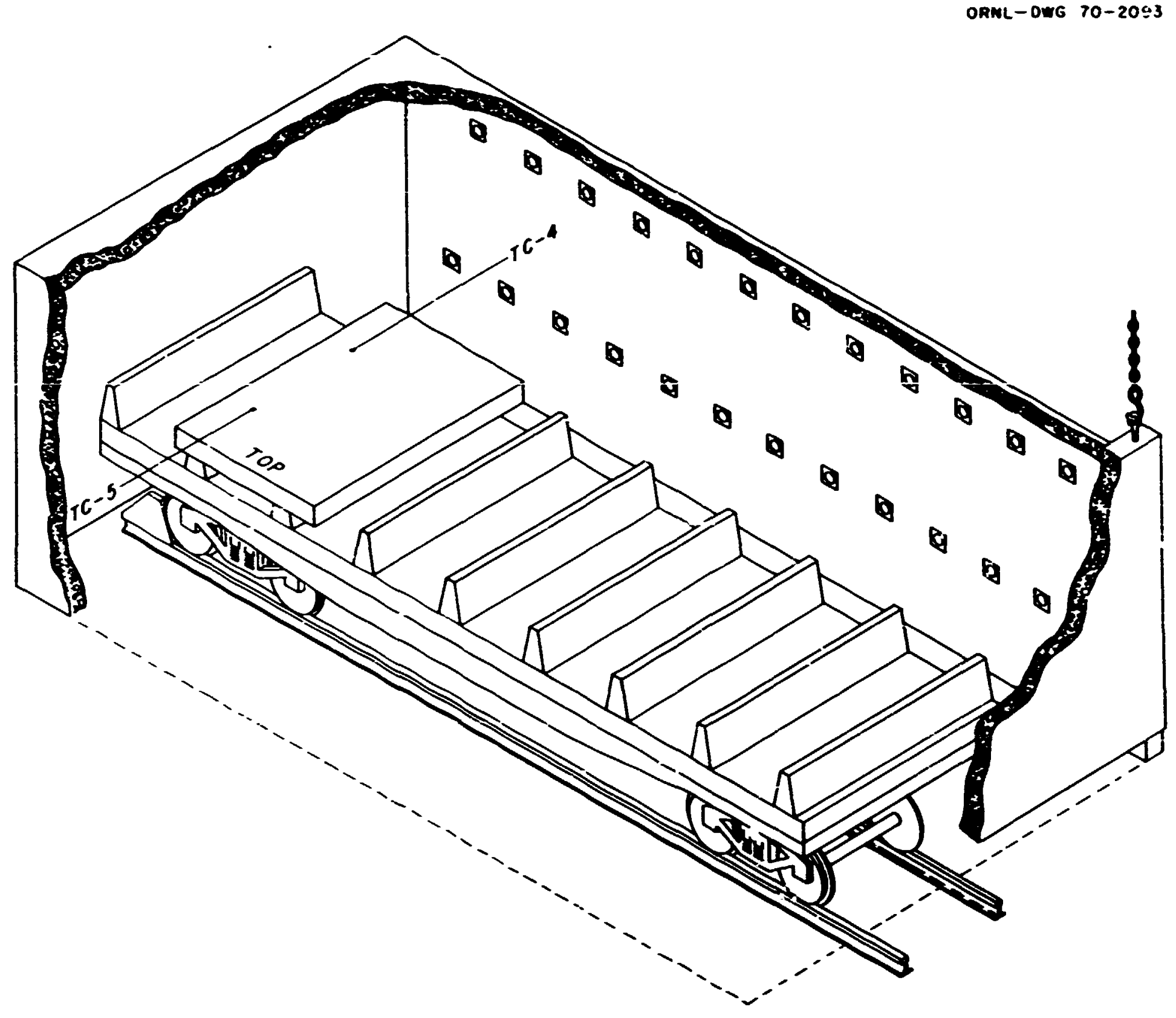

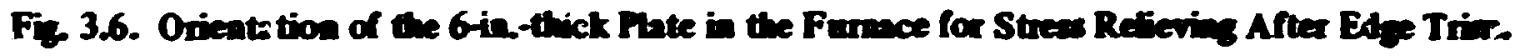

it was during the rolling operation. This system is explained in detail in a guide 4 wich has been prepared for use by HSST Program participants.

The plate was preheated to about $300^{\circ} \mathrm{F}$ and gas cut along the scribed lines (see Fig. 3.8). Double-J weld-joint preparations were then machined on the appropriate edges. Plate sections 11A and 11B were joined to form one weldment. The remaining plate sections were rejuined along the new cut lines (see Fig. 3.9) to form a second weldment. The weiding parameters ior the ó-in.-thick weidir were essentialiy it te the as for those described in Sect. H.3.

During magnetic particle inspection of the weldments, numerous indications were found on the bottom surface of the larger weldment, adjacent to the weld seams (see Fig-3.10). Each was located in areas where heavy bracing had been welded to the plate sections to minimize warpage during welding of the seams. The indications were removed by air-arc gouging and reinspectert to ascure that the areas were free of

\footnotetext{
4"A Gujde for Material Control and Data Control for the Heary Section Steel Technology Program," available through in office of the Program Director.
} 


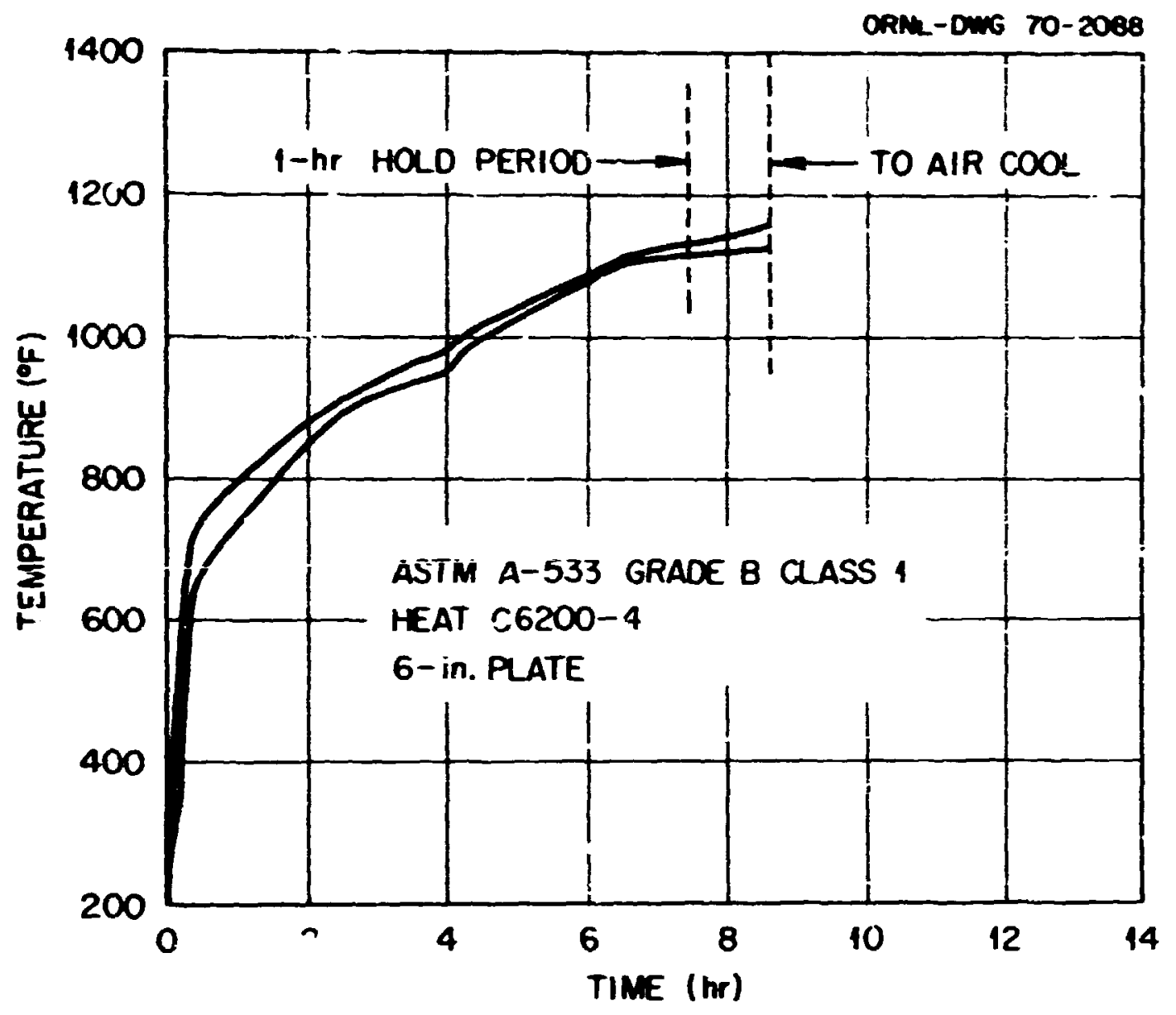

Fie 3.7. Spread in Thermocouple Reading Duing the Short-Term Stress Relief After Trimming.

indications. The gouged-out areas were then repaired by the manuai: metal-arc process, ground flush, and reinspected. In most cases it was necessary to remove about $1 / 4$ in. $(3 / 8$ in. max) of metal to reach an indication-free surface. No magnetic particle indications were found during inspection of the smaller weldment.

Each weld seam was then radiographed in accordance with the requirements of Sect. III for class A nuclear vessels. Four areas were found in the 12-ft seam (see Fig. 3.10) that were considered to be unacceptable by the applicable specification. Each appeared to be an area of lack of penetration near the root of the weld. The areas were explored by chipping and found to lie about $1^{3 / 4}$ in. below the bottom surface.

On completion of repair welding, the seams were re-x-rayed, and it was found that the indication located 36 in. from the plate edge was still present. The HSST staff decided that this indication, though considered unacceptable by Sect. III criteria, may actually be useful to the investigative program and requested that Combustion ship the weldment as is. (The othei thié incications were repaired satisfactorily.)

The weldments received an intermediate postweld heat treatment (PWHT) at $1150 \pm 25^{\circ} \mathrm{F}$ for $10 \mathrm{hr}$. The purchase order specified that each weldment should receive a final PWHT of $1150 \pm 25^{\circ} \mathrm{F}$ for $40 \mathrm{hr}$ and a heating rate not to exceed $100^{\circ} \mathrm{F} / \mathrm{hr}$. However, an infortunate series of events contributed to a deviation from the prescribed heat treatment. The deviations enumerated by Combustion are as follows:

The prescribed heat treatment was in progress for $10 \mathrm{hr}$ when furnace trouble forced them to shut down fe: repairs.

Sometime later (presumably the weldnents returned to ambient temperature) the furnace was repaired, and the PWHT was restarted. While raising the furnace to the prescribed temperature, the heating rate at 

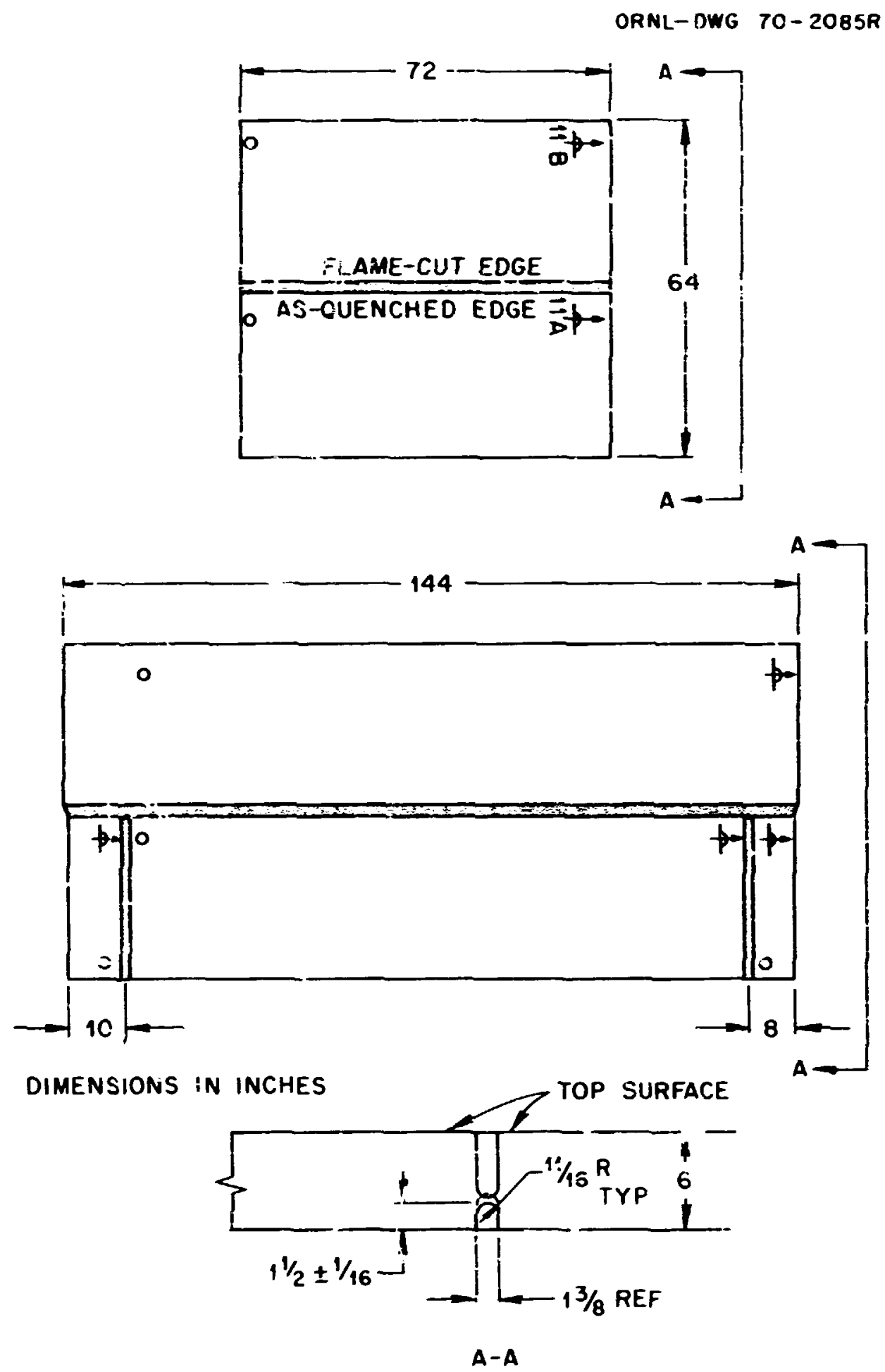

Fig. 3.9. Woldments Made by Rejoining the 6-in.-thict Plate. 


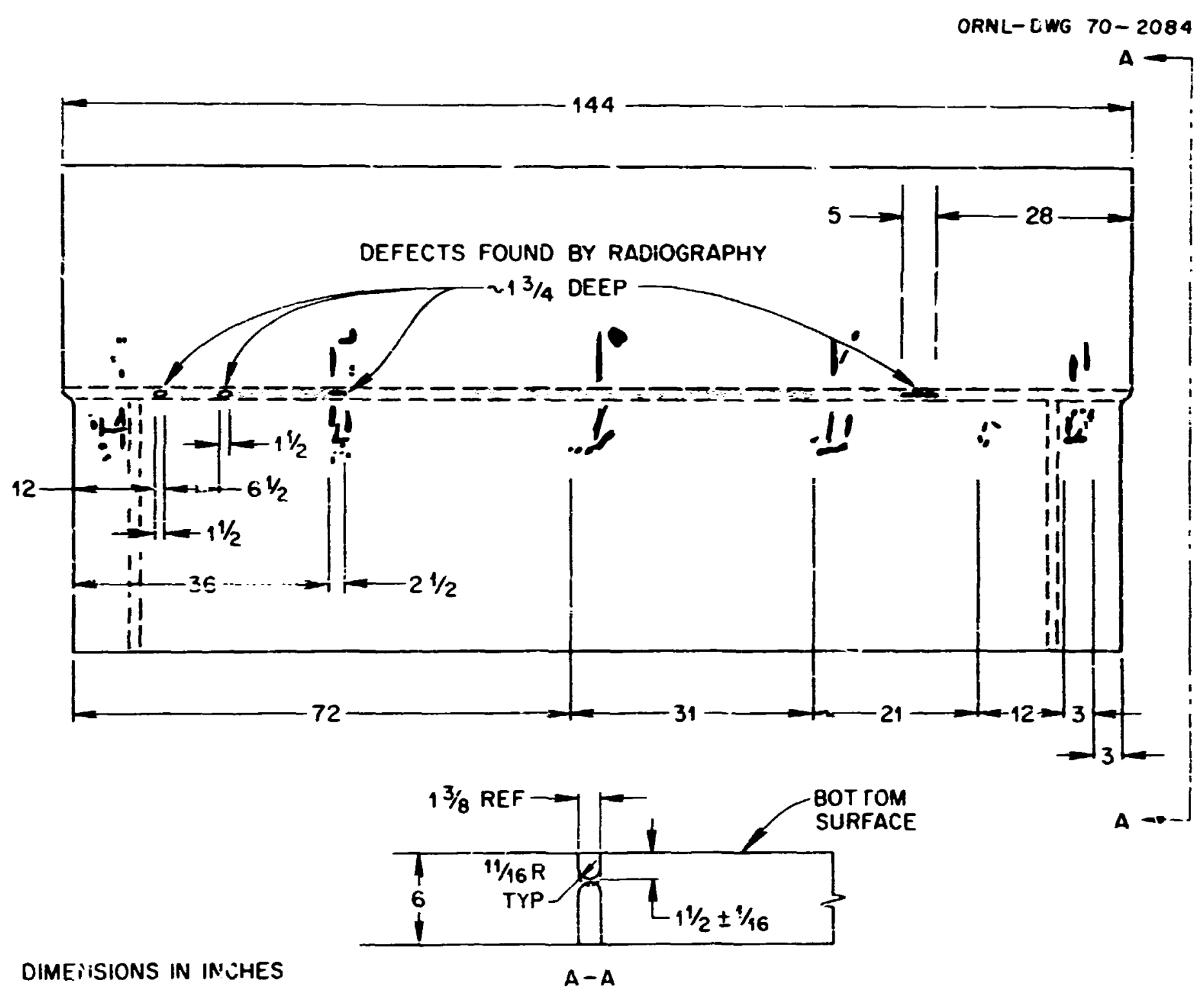

Fig. 3.10. Location of Magnetic Particle Indications and Weld Imperfections Found by Eadiographic Inspection. 


\section{APPENDIX}

ATTACHMENT 2A

DATE: AUGUST 4,1966

SBEET : 1 OF 4

ULTRASONIC TEST SPECIFICATION NUMBER 1

(Longitudical Wave Pulse Echo Testing of Plate)

\subsection{SCOPE:}

1.1 This specíication covers the examination procedure s.t recording requirements for the pulse echo "Itrasonic inspection of rolled carbon and alioy stael plates, 4" through 13" in thickness, of fully killed firebox or higher quality by the longitudinal (normal) bean method. It was developed to detect discontinuities parallel to the rolled surfaces.

1.2 This test shall be applied 1) when the plate is in the flat condition and 2) after the piate has been hot forned, quenched and tempered.

\subsection{APPARATUS:}

2.1 The test shall be performed using ultrasonic equipent of the pulse-echo longitudinal bead iype which shall provide linear presentation, within \pm 57 to at least $7 \mathrm{~s}$ i of full screen height.

2.2 Tbe transducer shall be 1-1/8" dianeter or 1" square.

2.3 Other search units may te used for evaluatiog and pin-pointing indications.

\subsection{PROCEDURE :}

3. i The fnspection shall be conducced in an araa free from operations that interfere with proper performance of the test.

3.2 Unless otherwise specified, vitrasonic inspection shall be made on elther major surface of the plate.

3.3 The plate surface shali be sufficiently clecin and smooth to maintain a good sonic coupling between the transducer and plate surface during scanning. Inis may involve suttabie means of scale removal. Local rough surfaces shall be conditioned by grinding. Any ipecifled identification which is rewoved when g,cindidg to achieve proper surfaca smoothness shaj.l be restired. 
ATTACBMENT A

DATE : AUGJST 4,1966

SHEET: 2 Of 4

ULTRASONIC TEST SPICIFICATION NO. 1

\subsection{PROCEDURE: (continued)}

3.4 The test shall be performed by one of the following aethods :

Direct contact, lenersion or liquid colunn coupling. A suitable couplant such as vater, soluble ofl or glycerine shall be used.

3.5 A noninal test frequency of $2 \frac{1}{2}$ Mc is reconended. Thickness, grain size or afcrostructure oí ine naterial and nature of the equipnent or method nay require a higher or lower test frequency. Transducers shall be used at their rated frequency. A clean, easily incerpreted trace pattern shall be produced during the inspection.

3.5.1 Each flat plate will be stanped wich a bench rk located near the glate idantification staming and all ladication locations referenced to this mark. Thla mark shell be located such that when the plate is cut to size and formed into a shell segator the ark will remain on the vessel.

\subsection{Scanntag}

3.6.1 Scanning shall be continuous over 1007 of the plate surface.

3.6.2 When d d scontinuitg conditivi is observed which approaches the Distance Anplitude Curve (D.A.C.), the transducer shall be postitoned to display the maximun indication so that the discontinuity can be eviliated by comparison with the D.A.C.

\subsection{ULTRASONIC EXAMINATION USING PLAT BOTTOM BOLE CALIBRATIOA:}

4.1 The following calibration and recording procedures shall be used:

4.2 Reference Block - A reference specimen shall be used to calibrate the equipment and establish recording criteria. Two (2) reference blocks shall be utilized: one (1) $7 i^{\prime \prime}$ thick to apply to plate thicknesses from 6" to 9" inclusive; one (1) 11" thick to apply to plate thicinesses in excess of 9 " and not exceeding 13". The material shall be acoustically 
ATTACBNEMT $2 \mathrm{~A}$

DATE: AUGUST 4,1966

SBEET: 3 of 4

OLTRASOHIC TEST SPECIFICATION NO.]

\section{i. O OLTRASOMIC EXAMIMATION USIAg Flat BOTTOM gOLE CALIBRATION:} (continued)

4.2 (continued)

sinilar to the plate undergoing examation. Acoustic sinflarity is presumé when comparison of the back reflection 81 gaals between the refereúce specinen and actual plate vithout change in Instrument setting shovs a variation of 257 or less.

4.2.1 The reference biocks sùil coniorn to figure I (lacer).

4.3 All reference blocks used on this progran shall be prepared by one supplier and ultrasonic response shall not vary by nore than 5 percent fromblock to block.

\subsection{CALIBRATIOA PROCEDURE:}

5.1. Flace the transducer over the hole producing the i. $q$ ghest Indication and edfust the sensitivity to approxinately $75 \pi$ of full scale. Without changlng the instruaent setti-gs, place the transducer over each hole and mark on the oscilloscope face the location and anplitude of the reflection fron eash flat botton hole. Connect these polats with a smooth curve. This is the D.A.C. and is the reference level for exanination and reporting.

5.2 Place the transducer over sound area of the reference block and note the back reflection amplitude using a calibrated attenuator or sinilar device if necessary. Record this anplitude and attenuator seteing.

5.3 Place the transducer on a sound area of the plate to be exanined in an area having a satisfactory surface condition. The instrument sensitivity may be adjusted so that the first back reflection equals that anplitude fron the reference plate. Any change in sensitivity fron that establisied on the reference block shall be recorded and reported in terns of dectbels of atcenuation or $z$ of screen height change in the reflection. 
ATTACHMENT 2A

\author{
DATE: AUGUST $4,1960^{\circ}$ \\ SHEET: 4 of 4 \\ ULTRASONIC TEST SPECIFICATION NO. 1
}

5.0 CALIBRATION PROCEDURE:

(continued)

5.4 Sensitivity adjustment shali be made only as describei in $; .2$ and 5.3 or when perforning recalibration procedure wh:ch will be done at least once per hour, or at any tine the equipment is moved, turned on or after any power lnterruption.

6.0 RECORDING:

6.1 Any Indication exceeding the D.A.C. shall be recorded. 6.1.1 Record the loss of back reflection anplitude
associated with any such Indications.

6.2 Any conplete $108 s$ of back reflection shall be recorded.

$6.3 A=5$ travelling indication shall be recorted.

6.4 In addition to the above, each plate shall be tested and the results recorded in accordance with A.S.M.E. Code Case 1338-2.

7.0 REPORTS:

7.1 All Indicationsi listed in 6.0 above shall be apped and repirtied on a report fork. A sample forn 13 enclosid as figure 2 (1ater). 


\section{DATE : AUGUST 4, 1966 \\ SHEET: 1 OF 3}

ULTRASOHIC TEST SPECIFICATION NUMBER 2

(Shea: Wave Pulse scho Testing of Plate)

\subsection{SCO?E:}

1.1 This specificatioc covers the exanination procedure and recording levels for ultrasonic shear ware inspection of otiél piáies. It was deveioped to detect discontinuities at an angle to the roljed surfaces.

1.2 This test shall be applied 1) while the piate is in the flat and 2) after the plate has been hot forned, quenched and tempered.

\subsection{TEST COHDITIOUS:}

2.1 The inspection shall be conducted in an area free fion operations that incerfere with proper performanze of the rest.

22 Pits, ripples, rust, scratches, dirt, loose scale and surface blexishes fron roiled-in scale shall be renoved to the excent necessary. Any specified identificatior utich is removel to achieve proper surfa.e saoothness shall be restored.

\subsection{APPARATUS:}

3.1 The test shall be perforned using an ultrasonic, puised, reflection-type instrument with operating frequencies sultable for the ssst. The instrunent shaid provide linear presentation, within $t 5 \pi$ up to at least $75 \pi$ of full screen height.

3.2 The search unit shall be a 45 degree (in stzel) shear wave type with an active transducer length of no nore than one inch. Search units of other sizes and angles nay be used for additional exploration and evaluation.

\section{C TEST FREQUENCY:}

4.1 The ultrasonic frequency selected for the test shall be woninally 2t Mc. One Mc transducet may be used when the plate exhibits an excessigty high noise level when $181 \mathrm{gig} 2 \frac{1}{4}$. 


\section{DATE : AUGUST 4,1966 \\ SHEET: 2 of 3}

ULTRASONIC TEST SPECIFICATION NO. 2

\subsection{CALIBRATIOH REFEBENCE STAMDARD:}

5.1 Reference Block - A reference specinen shall be used to calibrate the equipment and catablish recording criteria. Tro ( $z$ ) reference blocks shall be utilized: one (1) 7łz" thick to afply to plate thicknesses fron ${ }^{\prime \prime}$ co $\hat{g}^{\prime \prime}$ inciusive, one (i) $i^{\prime \prime}$ thick to apply to plate thicknesses in excess of $9 "$ and not exceeding 13". The naterial shall be acoust cally sinflar to the piate undergoing exantation.

Acoustic sindlarity is presuned when conparison of the back reflection signals between the reference specinen and actual plate whout change in instruwent setting shows a variation of 257 or less.

\subsubsection{Ine reference blocks shall conforn to} fionre 1 (later).

5.2 1:1 reference blocks used on this progran shall be frepared by one supplier and witrasonfc resposse shall nct vary by more than 5 percent fron block :o block.

\subsection{CALIBRATION PROCEDURE:}

6.1 A Distance Alplitude Curve (D.A.C.) shall be established using the series of cide drillea hoies in $t b$ ? reference block as reflectors. Ite hole nearest the test. surface shall establiah the first and last points on the curve. The first fint shall be established using the direct reflection (< $\frac{1}{2}$ node) fron this bole and the last point shall be estabi ished is the indirect rériecrion fron this hoie (nore than half node but less than a full node). Any other two holes nay be used to complete she curve. See ilgure? (later).

6.1.1 The higheat poin: or the D.A.C. shall be set to $75 z$ of full screen anplitude.

6.2 In order to compensate for variations in surface and attenuation, without changing instrunent settings, the back zeflection anplitude of a longitudinal transducer on a sound area of the test block shall be deterained and recorded usiag a callbrated attenuator, if necessary. On eacb new piate or when recallbration is necessa, $y$, the 


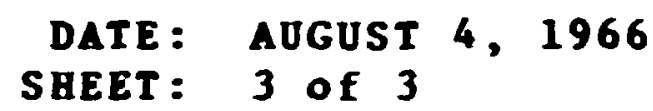

\author{
ULTRASONIC TEST SPECIPICATION NO. 2
}

\begin{abstract}
longitudinal transducer shall be placed on a sound area of the plate uudergoing exanination and with Instrunent gain control, adjust the bacl: reflection to the original anplitude.
\end{abstract}

\title{
7.0 IMSPECTIOM PFOCEDURE:
}

7.1 Scanning shall be done over 1007 of the plate surface by use of a sutable couplant such as water, o11, Gr glycerine. Scanning shall be performed by placing the search unit near onc edge with the sound bean directed touard the sane edge and noving the search unit in direction perpendicular to the edge to a location two plate thicknesses bejond the plate center. This scanring procedure shall be repeated along all four edges of the plate with a ininum sverlap of 107 with each pass.

7.2 The search unit shall be positioned to obtain a maxinue reflection fron the observed discontinuity. Record those Indications which exceed the D.A.C.

7.3 Each plate shall be stanped with a bench aark in the ared of the plate identification stanping such that all discontinuity indications can be lccated and reported in zeference to this ark and, when testing Is perforned arter forning, subsequient zesilis =ay be related to the previous test.

\subsection{REPORT:}

8.1 Indications described in 7.2 shall be recoried and apped on a raport forn. A sanple form is enclosed as Eะकि:=a 3 (later). 